\title{
Truncated Actin-Targeting Macrolide Derivative Blocks Cancer Cell Motility and Invasion of Extracellular Matrix
}

Bhavin V. Pipaliya, ${ }^{a \#}$ Daria N. Trofimova, ${ }^{b \#}$ Rebecca L. Grange, ${ }^{a \#}$ Madhu Aeluri, ${ }^{a \#}$ Xu Deng, ${ }^{c, d}$ Kavan Shah, ${ }^{c}$ Andrew W. Craig, ${ }^{c}$ John S. Allingham, ${ }^{b}$ and P. Andrew Evans ${ }^{a, d}{ }_{*}$

${ }^{a}$ Department of Chemistry, Queen's University, 90 Bader Lane, Kingston, ON K7L 3N6, Canada

${ }^{b}$ Department of Biomedical \& Molecular Sciences, Queen's University, 18 Stuart Street, Kingston, ON K7L 3N6, Canada

${ }^{c}$ Cancer Biology \& Genetics Division, Queen's Cancer Research Institute, 18 Stuart Street, Kingston, ON K7L 3N6, Canada

${ }^{d}$ Xiangya School of Pharmaceutical Sciences, Central South University, Changsha 410013, Hunan, P. R. of China

${ }^{\#}$ These authors contributed equally.

\section{Contents of Supplementary Information:}

\begin{tabular}{|c|l|c|}
\hline 1. & General Information & S2 \\
\hline 2. & Experimental Procedures and Spectral Data & S3 \\
\hline 3. & Table S1. X-Ray Data Collection and Refinement Statistics & S23 \\
\hline 4. & Figure S1. Effects of MycB and Analogue 2 on Actin Polymerization & S24 \\
\hline 5. & Figure S2. ECM Degradation Assay & S25 \\
\hline 6. & Figure S3. LIGPLOT of the Actin-MycB (A) and Actin-2 (B) Contacts & S26 \\
\hline 7. & Table S2. Structure-Activity Relationship Studies of Truncated Myc B & \\
\hline 8. & References & S27 \\
\hline 9. & Copies of NMR Spectra & S28 \\
\hline
\end{tabular}




\section{General Information}

All reactions were carried out in anhydrous solvent using commercially available reagents that were used as received. Dichloromethane, tetrahydrofuran (THF) and diethyl ether were dried by passage through activated alumina columns. Dimethylformamide (DMF) and isopropanol were dried over activated $4 \AA$ molecular sieves. Dimethylethylamine and triethylamine were distilled from calcium hydride and stored over potassium hydroxide. 1,8-Diazabicyclo[5.4.0]undec-7-ene (DBU) was distilled from potassium hydroxide. Analytical thin-layer chromatography (TLC) was performed on pre-coated $0.2 \mathrm{~mm}$ thick silica gel $60-\mathrm{F}_{254}$ plates (Merck); visualized using UV light and then a solution of $\mathrm{KMnO}_{4}$, ceric ammonium molybdate or ninhydrin, followed by heating. All compounds were purified by flash chromatography using silica gel 60 (40-63 $\mu \mathrm{m}$, Silicycle). Solvents for extraction and flash chromatography were reagent grade. Optical rotations $\left([\alpha]_{\mathrm{D}}^{\circ \mathrm{C}}\right)$ were measured on an Anton Parr MCP 200 polarimeter with a tungsten halogen lamp (589 nm) at the stated temperature (indicated in ${ }^{\circ} \mathrm{C}$ as superscript) using a $0.7 \mathrm{~mL}$ quartz cell of $100 \mathrm{~mm}$ length; solution concentrations (c) are given in $\mathrm{g} / 100 \mathrm{~mL} .{ }^{1} \mathrm{H}$ and ${ }^{13} \mathrm{C}$ NMR were recorded on a Bruker Avance DRX-500 spectrometer in $\mathrm{CDCl}_{3}$ at ambient temperature; chemical shifts $(\delta)$ are presented in ppm and calibrated using the signal of the residual undeuterated solvent as an internal reference $\left(\delta_{\mathrm{H}}=7.26 \mathrm{ppm}\right.$ for $\left.\mathrm{CDCl}_{3}\right)$ and using the signal of the deuterated solvent for ${ }^{13} \mathrm{C} \mathrm{NMR}\left(\delta_{\mathrm{C}}=77.16 \mathrm{ppm}\right.$ for $\left.\mathrm{CDCl}_{3}\right) .{ }^{1} \mathrm{H}$ NMR data are reported as follows: chemical shift (multiplicity, $1^{\text {st }}$ order spin system if available, coupling constant and integration). Coupling constants $(J)$ are reported in $\mathrm{Hz}$, and apparent splitting patterns are designated using the following abbreviations: s (singlet), $\mathrm{d}$ (doublet), $\mathrm{t}$ (triplet), $\mathrm{q}$ (quartet), quintet, sextet, septet, octet, m (multiplet), br. (broad), app. (apparent) and combinations thereof. ${ }^{13} \mathrm{C}$ NMR spectra with proton decoupling were described with the aid of an APT sequence, separating methylene and quaternary carbons (e, even) from methyl and methine carbons (o, odd). For $N$-ethylformamides existing as mixtures of rotamers, distinguishable resonances of the minor rotamer are denoted with an asterisk $*[]$ and $*()$ in ${ }^{1} \mathrm{H}$ and ${ }^{13} \mathrm{C} \mathrm{NMR}$, respectively. Infrared spectra were obtained on an Agilent Technologies Cary 630 FT-IR (ATR) spectrometer; wavenumbers (v) are given in $\mathrm{cm}^{-1}$; and the abbreviations $\mathrm{w}$ (weak, <33\%), m (medium, 33-66\%), s (strong, >66\%), vs

(very strong, $\geq 95 \%$ ) and br (broad) are used to describe the relative intensities of the IR absorbance bands. Mass spectra were obtained through the Chemistry Department Mass Spectrometry Service at Queen's University. 


\section{Experimental Procedures and Spectral Data}

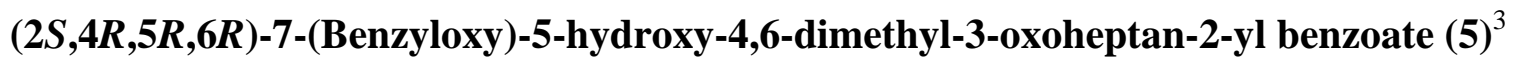
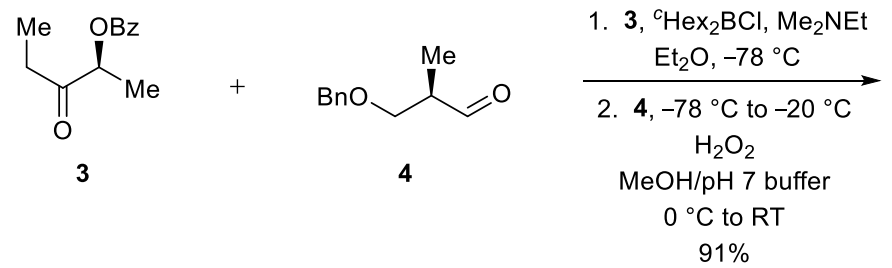

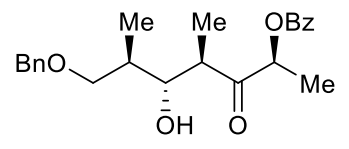

5

$d r=9: 1$

Dimethylethylamine $(0.79 \mathrm{~mL}, 6.98 \mathrm{mmol}, 1.8$ equiv.) was added via syringe to a stirred solution of chlorodicyclohexylborane $(1.28 \mathrm{~mL}, 5.82 \mathrm{mmol}, 1.5$ equiv. $)$ in diethyl ether $(10 \mathrm{~mL})$ at $-78{ }^{\circ} \mathrm{C}$ under an atmosphere of argon. A solution of $(S)$-3-oxopentan-2-yl benzoate $(3)^{1}(0.80 \mathrm{~g}, 3.88 \mathrm{mmol})$ in diethyl ether $(6 \mathrm{~mL})$ was added via syringe and the resulting white suspension stirred at $-78{ }^{\circ} \mathrm{C}$ for $\mathrm{ca}$. 10 minutes before warming to $0{ }^{\circ} \mathrm{C}$ where it was stirred for $c a .2$ hours. The mixture was then recooled to $-78^{\circ} \mathrm{C}$, and a solution of freshly prepared (R)-3-(benzyloxy)-2-methylpropanal $(\mathbf{4})^{2}(1.00 \mathrm{~g}$, $5.62 \mathrm{mmol}, 1.45$ equiv. $)$ in diethyl ether $(8 \mathrm{~mL})$ was added dropwise via syringe. The reaction was maintained at $-78{ }^{\circ} \mathrm{C}$ for $c a .2$ hours and then stirred at $-20{ }^{\circ} \mathrm{C}$ for an additional $c a .14$ hours. The reaction was quenched by the addition of methanol $(15 \mathrm{~mL}), \mathrm{pH} 7$ buffer solution $(15 \mathrm{~mL})$ and $35 \%$ aqueous hydrogen peroxide solution $(15 \mathrm{~mL})$ at $0{ }^{\circ} \mathrm{C}$. The resulting solution was then stirred at room temperature for $c a .2$ hours before being partitioned between water and dichloromethane. The organic phases were combined, washed with saturated aqueous $\mathrm{NaCl}$ solution, dried (anhyd. $\mathrm{Na}_{2} \mathrm{SO}_{4}$ ), filtered and concentrated in vacuo to afford the crude product. Purification by flash chromatography $\left(\mathrm{SiO}_{2}\right.$, gradient elution with 5:95 to 10:90 ethyl acetate/hexane) afforded the title compound 5 (1.36 g, 91\% yield) as a colorless oil with 9:1 diastereoselectivity.

$[\alpha]_{\mathrm{D}}^{20}+11.8\left(\mathrm{c}=0.45, \mathrm{CHCl}_{3}\right)\left\{\right.$ Lit. $\left.^{3}[\alpha]_{\mathrm{D}}^{20}+1.3\left(\mathrm{c}=1.3, \mathrm{CHCl}_{3}\right)\right\}$.

${ }^{1}$ H NMR $\left(500 \mathrm{MHz}, \mathrm{CDCl}_{3}\right) \delta$ 8.09-8.07 (m, 2H), 7.58 (app. tt, $\left.J=7.5,1.4 \mathrm{~Hz}, 1 \mathrm{H}\right), 7.47-7.43(\mathrm{~m}$, 2H), 7.35-7.26 (m, 5H), 5.44 (q, $J=7.0 \mathrm{~Hz}, 1 \mathrm{H}$ ), 4.46 (s, 2H), 3.70 (app. dt, $J=7.8,4.4 \mathrm{~Hz}, 1 \mathrm{H}$ ), 3.57 (dd, $J=9.3,4.7 \mathrm{~Hz}, 1 \mathrm{H}), 3.55$ (dd, $J=9.3,4.7 \mathrm{~Hz}, 1 \mathrm{H}$ ), 3.14 (app. quintet, $J=7.3 \mathrm{~Hz}, 1 \mathrm{H}$ ), 3.06 (d, $J$ $=7.6 \mathrm{~Hz}, 1 \mathrm{H}), 1.97(\mathrm{qtd}, J=7.0,4.6,2.5 \mathrm{~Hz}, 1 \mathrm{H}), 1.53(\mathrm{~d}, J=7.0 \mathrm{~Hz}, 3 \mathrm{H}), 1.22(\mathrm{~d}, J=7.1 \mathrm{~Hz}, 3 \mathrm{H})$, $1.07(\mathrm{~d}, J=7.1 \mathrm{~Hz}, 3 \mathrm{H})$. 
IR (neat) 3496 (br, w), 3062 (w), 3030 (w), 2967 (w), 2934 (w), 2875 (w), 1714 (s), 1601 (w), 1584

(w), 1493 (w), 1452 (m), 1376 (w), 1362 (w), 1314 (m), 1264 (s), 1205 (w), 1176 (w), 1112 (s), 1096

(s), 1070 (s), 1026 (m), 1002 (m), 985 (s), 960 (m), 906 (w), 852 (w), $736(\mathrm{~m}), 710$ (s), $698(\mathrm{~s}) \mathrm{cm}^{-1}$.

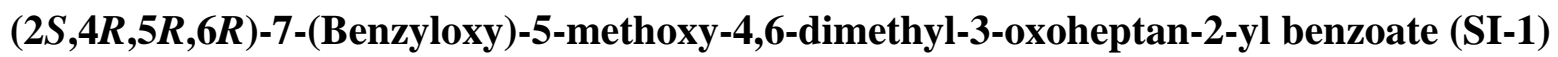
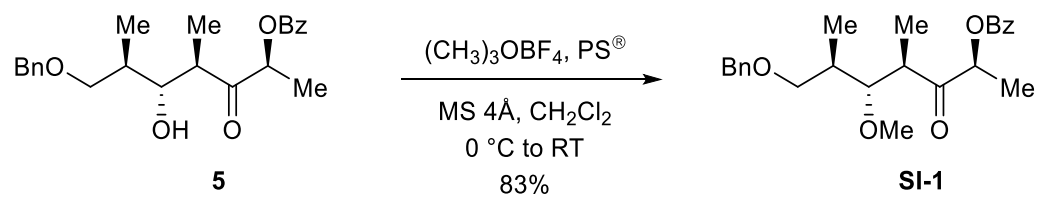

$4 \AA$ Molecular sieves $(3.1 \mathrm{~g})$ were weighed into a $100 \mathrm{~mL}$ round-bottom flask and flame dried under high vacuum. A solution of the $\beta$-hydroxy ketone 5 (1.03 g, $2.68 \mathrm{mmol})$ in dichloromethane $(40 \mathrm{~mL})$ was then added via syringe and the mixture was cooled with stirring to $0{ }^{\circ} \mathrm{C}$ under an atmosphere of argon. Proton-sponge ${ }^{\circledR}(2.01 \mathrm{~g}, 9.38 \mathrm{mmol}, 3.5$ equiv. $)$ and trimethyloxonium tetrafluoroborate $(0.872$ g, 5.89 mmol, 2.2 equiv.) were sequentially added and the resulting reaction mixture stirred for $c a .30$ minutes before being warmed to room temperature and stirred for an additional $c a .16$ hours. ${ }^{4}$ The reaction mixture was then diluted with ethyl acetate $(15 \mathrm{~mL})$ and filtered through a pad of Celite ${ }^{\circledR}$, washing thoroughly with ethyl acetate. The combined organic phases were washed with water, $10 \%$ aqueous citric acid solution and saturated aqueous $\mathrm{NaCl}$ solution, dried (anhyd. $\mathrm{Na}_{2} \mathrm{SO}_{4}$ ), filtered and concentrated in vacuo to afford the crude product. Purification by flash chromatography $\left(\mathrm{SiO}_{2}\right.$, gradient elution with 5:95 to 10:90 ethyl acetate/hexane) afforded the title compound SI-1 (0.886 g, $83 \%$ ) as a colorless oil with $\geq 19: 1$ diastereoselectivity.

$[\alpha]_{\mathrm{D}}^{22}-5.2\left(\mathrm{c}=1.02, \mathrm{CHCl}_{3}\right)$.

${ }^{1} \mathbf{H}$ NMR $\left(500 \mathrm{MHz}, \mathrm{CDCl}_{3}\right) \delta 8.08(\mathrm{~d}, J=7.4 \mathrm{~Hz}, 2 \mathrm{H}), 7.56(\mathrm{t}, J=7.3 \mathrm{~Hz}, 1 \mathrm{H}), 7.43(\mathrm{t}, J=7.6 \mathrm{~Hz}$, 2H), 7.33-7.27 (m, 5H), 5.37 (q, J=7.0 Hz, 1H), 4.46 (s, 2H), 3.60 (dd, J = 9.0, $6.6 \mathrm{~Hz}, 1 \mathrm{H}), 3.45$ (dd, $J=10.1,1.4 \mathrm{~Hz}, 1 \mathrm{H}), 3.30-3.25(\mathrm{~m}, 1 \mathrm{H}), 3.28(\mathrm{~s}, 3 \mathrm{H}), 3.23-3.19(\mathrm{~m}, 1 \mathrm{H}), 2.15-2.08(\mathrm{~m}, 1 \mathrm{H}), 1.51$ (d, $J=7.0 \mathrm{~Hz}, 3 \mathrm{H}), 1.12(\mathrm{~d}, J=6.9 \mathrm{~Hz}, 3 \mathrm{H}), 1.06(\mathrm{~d}, J=7.0 \mathrm{~Hz}, 3 \mathrm{H})$.

${ }^{13}$ C NMR (125 MHz, $\mathrm{CDCl}_{3}$ ) $\delta 210.38$ (e), 165.92 (e), 138.72 (e), 133.29 (o), 129.93 (o), 129.88 (e), 128.51 (o), 128.49 (o), 127.62 (o), 127.56 (o), 86.18 (o), 75.23 (o), 73.22 (e), 71.69 (e), 61.30 (o), 45.66 (o), 35.54 (o), 16.12 (o), 15.23 (o), 14.47 (o). 
IR (neat) 3063 (w), 3030 (w), 2967 (w), 2935 (w), 2877 (w), 1716 (s), 1602 (w), 1584 (w), 1494 (w), 1452 (m), 1361 (w), 1314 (m), 1264 (s), 1201 (w), 1176 (w), 1112 (s), 1084 (s), 1071 (s), 1027 (m), 1005 (m), 971 (m), 903 (w), $853(\mathrm{w}), 736(\mathrm{~m}), 710(\mathrm{~s}), 697(\mathrm{~s}) \mathrm{cm}^{-1}$.

HRMS (ESI, [M+Na] $]^{+}$) calcd for $\mathrm{C}_{24} \mathrm{H}_{30} \mathrm{NaO}_{5} 421.1986$, found 421.1971 .

$(3 R, 4 S, 5 R, 6 R)-7-(B e n z y l o x y)-5-m e t h o x y-4,6-d i m e t h y l h e p t-1-e n-3-o l \quad(7)^{5}$ and $(3 S, 4 S, 5 R, 6 R)-7$ (Benzyloxy)-5-methoxy-4,6-dimethylhept-1-en-3-ol (8) ${ }^{5}$

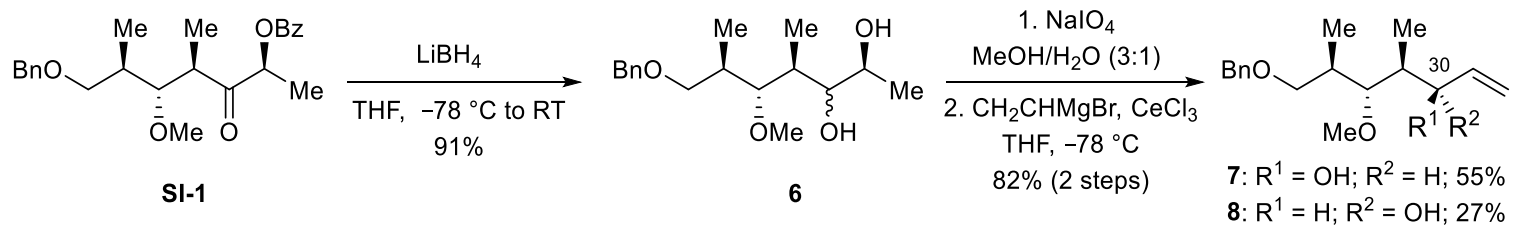

$\mathrm{LiBH}_{4}(76 \mathrm{~mL}, 152 \mathrm{mmol}, 17$ equiv., $2 \mathrm{M}$ in THF) was slowly added dropwise to a stirred solution of ketone SI-1 (3.57 g, $8.96 \mathrm{mmol})$ in THF $(40 \mathrm{~mL})$ at $-78{ }^{\circ} \mathrm{C}$ under an atmosphere of argon. The reaction mixture was allowed to warm to room temperature and stirred for $c a$. 16 hours (TLC control). The reaction was then quenched by the addition of a saturated aqueous solution of Rochelle salt at 0 ${ }^{\circ} \mathrm{C}$ and stirred for $\mathrm{ca} .2$ hours at room temperature. The resulting mixture was then partitioned between diethyl ether and water and the organic phases were combined, dried (anhyd. $\mathrm{Na}_{2} \mathrm{SO}_{4}$ ), filtered and concentrated in vacuo to afford the crude product. Purification by flash chromatography $\left(\mathrm{SiO}_{2}\right.$, gradient elution with 2:98 to 5:95 methanol/dichloromethane) afforded compound 6 (2.42 g, $91 \%)$ as a light yellow oil as a mixture of diastereomers.

Sodium periodate (3.68 g, $17.21 \mathrm{mmol}, 6.0$ equiv.) was added to a solution of the diol 6 (850 $\mathrm{mg}, 2.87$ mmol, 1.0 equiv.) in methanol/water $(29 \mathrm{~mL}, 3: 1)$ at room temperature and the mixture was stirred for ca. 30 minutes (TLC control). The reaction was then quenched by the addition of water (65 $\mathrm{mL})$ and partitioned with diethyl ether. The combined organic phases were dried (anhyd. $\mathrm{MgSO}_{4}$ ), filtered and concentrated in vacuo to afford the crude aldehyde that was directly used in next step without further purification.

Anhydrous cerium(III) chloride (1.51 g, $6.11 \mathrm{mmol}, 2.13$ equiv.) was suspended in THF (20 mL) at 0 ${ }^{\circ} \mathrm{C}$ and then warmed to room temperature where it was stirred for $c a .2 .5$ hours under an atmosphere of argon. The suspension was then cooled to $-78{ }^{\circ} \mathrm{C}$ and vinylmagnesium bromide $(5.74 \mathrm{~mL}, 5.74$ mmol; 2.0 equiv., 1.0 M in THF.) was added dropwise via syringe. The resulting yellow suspension was stirred at $-78{ }^{\circ} \mathrm{C}$ for $c a .2$ hours and then a solution of the crude aldehyde in THF (5 mL) was 
added dropwise via syringe and the reaction was stirred at $-78{ }^{\circ} \mathrm{C}$ for an additional $c a .2$ hours (TLC control). The mixture was warmed to $0{ }^{\circ} \mathrm{C}$ and quenched by the addition of saturated aqueous $\mathrm{NH}_{4} \mathrm{Cl}$ solution. The reaction mixture was then partitioned between ethyl acetate and water and the organic phases were combined, washed with saturated aqueous $\mathrm{NaCl}$ solution, dried (anhyd. $\mathrm{Na}_{2} \mathrm{SO}_{4}$ ), filtered and concentrated in vacuo to afford the crude product as a mixture of diastereoisomers. Purification by flash chromatography $\left(\mathrm{SiO}_{2}\right.$, gradient elution with 5:95 to 10:90 ethyl acetate/pentane) afforded the allylic alcohols 7 (0.439 g; 55\%) and $8(0.216 \mathrm{~g} ; 27 \%)$ as colorless oils.

\section{(3R,4S,5R,6R)-7-(Benzyloxy)-5-methoxy-4,6-dimethylhept-1-en-3-ol (7)}

$[\alpha]_{\mathrm{D}}^{20}+25.7\left(\mathrm{c}=1.03, \mathrm{CHCl}_{3}\right)$.

${ }^{1} \mathbf{H}$ NMR $\left(500 \mathrm{MHz}, \mathrm{CDCl}_{3}\right) \delta$ 7.36-7.28 (m, 5H), $5.82(\mathrm{ddd}, J=17.0,10.9,4.8 \mathrm{~Hz}, 1 \mathrm{H}), 5.28(\mathrm{~d}, J=$ $17.2 \mathrm{~Hz}, 1 \mathrm{H}), 5.14(\mathrm{~d}, J=10.6 \mathrm{~Hz}, 1 \mathrm{H}), 4.51(\mathrm{~s}, 2 \mathrm{H}), 4.47-4.45(\mathrm{~m}, 1 \mathrm{H}), 3.53(\mathrm{~d}, J=4.6 \mathrm{~Hz}, 2 \mathrm{H})$, 3.53 (br. s, $1 \mathrm{H}), 3.46$ (s, 3H), 3.24 (dd, $J=7.5,4.1 \mathrm{~Hz}, 1 \mathrm{H}), 2.14-2.07(\mathrm{~m}, 1 \mathrm{H}), 1.87-1.81(\mathrm{~m}, 1 \mathrm{H})$, $1.02(\mathrm{~d}, J=7.1 \mathrm{~Hz}, 3 \mathrm{H}), 1.00(\mathrm{~d}, J=7.2 \mathrm{~Hz}, 3 \mathrm{H})$.

${ }^{13}$ C NMR (125 MHz, $\mathrm{CDCl}_{3}$ ) $\delta 139.78$ (o), 138.71 (e), 128.46 (o), 127.73 (o), 127.68 (o), 114.41 (e), 88.44 (o), 73.28 (e), 72.32 (e), 72.30 (o), 61.65 (o), 38.80 (o), 36.84 (o), 15.26 (o), 11.83 (o).

IR (neat) 3479 (br, w), 3063 (w), 3029 (w), 2967 (w), 2910 (w), 2870 (w), 1495 (w), 1453 (m), 1364 (w), 1308 (w), 1258 (w), 1200 (w), 1154 (w), 1082 (vs), 1027 (m), 986 (m), 966 (m), 918 (m), 816 (w), $734(\mathrm{~s}), 696(\mathrm{~s}) \mathrm{cm}^{-1}$.

HRMS (ESI, [M+Na] $]^{+}$) calcd for $\mathrm{C}_{17} \mathrm{H}_{26} \mathrm{NaO}_{3} 301.1774$, found 301.1775 .

(3S,4S,5R,6R)-7-(Benzyloxy)-5-methoxy-4,6-dimethylhept-1-en-3-ol (8) $[\alpha]_{\mathrm{D}}^{21}-2.9\left(\mathrm{c}=0.47, \mathrm{CHCl}_{3}\right)$

${ }^{1} \mathrm{H}$ NMR $\left(500 \mathrm{MHz}, \mathrm{CDCl}_{3}\right) \delta 7.36-7.26(\mathrm{~m}, 5 \mathrm{H}), 5.86(\mathrm{ddd}, J=17.2,10.1,7.1 \mathrm{~Hz}, 1 \mathrm{H}), 5.26(\mathrm{~d}, J=$ $17.1 \mathrm{~Hz}, 1 \mathrm{H}), 5.16(\mathrm{~d}, J=10.3 \mathrm{~Hz}, 1 \mathrm{H}), 4.51(\mathrm{~d}, \mathrm{~A}$ of $\mathrm{AB}, J=12.1 \mathrm{~Hz}, 1 \mathrm{H}), 4.48(\mathrm{~d}, \mathrm{~B}$ of $\mathrm{AB}, J=$ $12.0 \mathrm{~Hz}, 1 \mathrm{H}$ ), 4.12 (app. t, $J=6.6 \mathrm{~Hz}, 1 \mathrm{H}$ ), 3.57 (dd, $J=8.8,4.9 \mathrm{~Hz}, 1 \mathrm{H}$ ), 3.47 (s, 3H), 3.43 (br. s, 1H), 3.44-3.38 (m, 1H), 3.13 (dd, $J=6.6,4.6 \mathrm{~Hz}, 1 \mathrm{H}$ ), 2.20-2.12 (m, 1H), 1.90 (app. sextet, $J=6.9$ $\mathrm{Hz}, 1 \mathrm{H}), 1.08(\mathrm{~d}, J=6.9 \mathrm{~Hz}, 3 \mathrm{H}), 0.87(\mathrm{~d}, J=6.9 \mathrm{~Hz}, 3 \mathrm{H})$.

${ }^{13}$ C NMR (125 MHz, $\mathrm{CDCl}_{3}$ ) $\delta 139.50$ (o), 138.74 (e), 128.46 (o), 127.68 (o), 127.61 (o), 116.05 (e), 89.50 (o), 76.45 (o), 73.25 (e), 72.17 (e), 61.00 (o), 40.92 (o), 37.10 (o), 15.68 (o), 15.06 (o). 
IR (neat) 3437 (br, w), 3064 (w), 3028 (w), 2966 (m), 2927 (m), 2888 (m), 1490 (w), 1453 (m), 1364 (m), 1304 (w), $1271(\mathrm{w}), 1201$ (w), 1151 (m), 1086 (s), 1074 (s), 1026 (m), 992 (m), 970 (m), 920 (s), $841(\mathrm{w}), 734(\mathrm{~s}), 697(\mathrm{~s}) \mathrm{cm}^{-1}$.

HRMS (ESI, [M+Na] $]^{+}$) calcd for $\mathrm{C}_{17} \mathrm{H}_{26} \mathrm{NaO}_{3} 301.1774$, found 301.1769.

\section{Conversion of 8 to 7:}

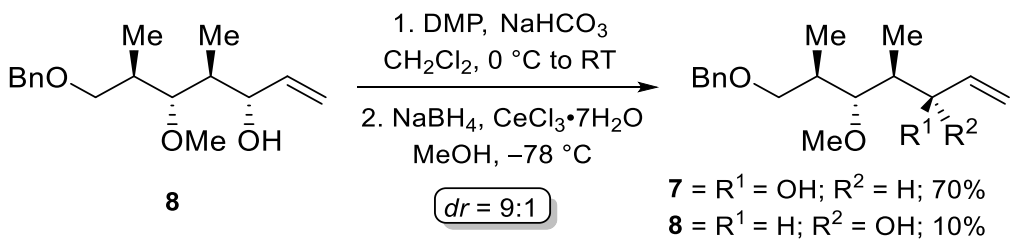

Sodium bicarbonate (2.70 g, $32.1 \mathrm{mmol}, 11.2$ equiv.) and Dess-Martin periodinane (2.68 g, 6.31 mmol, 2.2 equiv.) were sequentially added to a stirred solution of the allylic alcohol 8 (0.80 g, 2.87 mmol) in degassed dichloromethane $(15 \mathrm{~mL})$ at $0{ }^{\circ} \mathrm{C}$ under an atmosphere of argon. The reaction mixture was allowed to warm to room temperature and stirred for $c a$. 2 hours (TLC control). The reaction was then quenched by the addition of a 1:1 mixture of saturated aqueous $\mathrm{NaHCO}_{3}$ and $\mathrm{Na}_{2} \mathrm{~S}_{2} \mathrm{O}_{3}$ solutions. The mixture was partitioned between dichloromethane and water and the organic phases were combined, washed with saturated aqueous $\mathrm{NaCl}$ solution, dried (anhyd. $\mathrm{Na}_{2} \mathrm{SO}_{4}$ ), filtered and concentrated in vacuo to afford the crude enone, which was directly used for next step without further purification.

Cerium(III) chloride heptahydrate (4.28 g, $11.48 \mathrm{mmol}, 4$ equiv.) was added in a single portion to a stirred solution of crude enone in methanol $(20 \mathrm{~mL})$ at room temperature under an atmosphere of argon and the mixture was stirred for $c a .15$ minutes. The reaction mixture was then cooled to $-78{ }^{\circ} \mathrm{C}$ and stirred for an additional $c a .15$ minutes at this temperature. $\mathrm{NaBH}_{4}(217 \mathrm{mg}, 5.75 \mathrm{mmol}, 2.0 \mathrm{eq})$ was added portionwise at $c a .15$ minutes intervals over one hour and stirring was continued for $c a .1$ hour at $-78{ }^{\circ} \mathrm{C}$ (TLC control). The resulting suspension was warmed to $0{ }^{\circ} \mathrm{C}$ and quenched by the addition of aqueous $1 \mathrm{~N} \mathrm{HCl}$ solution. The reaction mixture was concentrated in vacuo to remove the methanol and the crude residue was partitioned between diethyl ether and water. The organic phases were combined, washed with saturated aqueous $\mathrm{NaHCO}_{3}$ solution, dried (anhyd. $\mathrm{Na}_{2} \mathrm{SO}_{4}$ ), filtered and concentrated in vacuo to afford the crude product. Purification by flash chromatography $\left(\mathrm{SiO}_{2}\right.$, gradient elution with 5:95 to 10:90 ethyl acetate/pentane) afforded the allylic alcohol 7 (0.563 g, 70\%) and $\mathbf{8}(0.079 \mathrm{~g}, 10 \%)$ as colorless oils. 


\section{(S)-\{[(2-Methylhex-5-en-3-yl)oxy]methyl $\}$ benzene $(10)^{6}$}

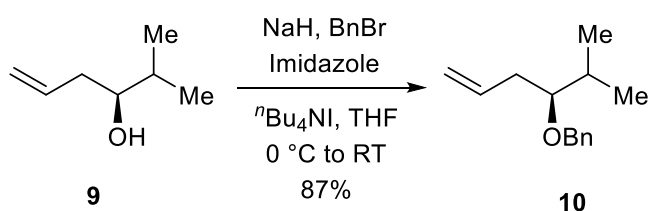

Sodium hydride (5.59 g, 233 mmol, 57\% dispersion in mineral oil, 4 equiv., washed with anhyd. hexane three times) was suspended in THF $(100 \mathrm{~mL})$ at $0{ }^{\circ} \mathrm{C}$ under an atmosphere of argon. A solution of the alcohol 9 (6.65 g, $58.2 \mathrm{mmol})$ in THF (20 mL) was added dropwise via syringe and then the suspension was stirred at $0{ }^{\circ} \mathrm{C}$ for $c a .30$ minutes. Imidazole $(198 \mathrm{mg}, 2.91 \mathrm{mmol}, 0.05$ equiv.), benzyl bromide ( $7.66 \mathrm{~mL}, 64.1 \mathrm{mmol}, 1.1$ equiv.) and tetra- $n$-butylammonium iodide $(2.15 \mathrm{~g}$, $5.82 \mathrm{mmol}, 0.1$ equiv.) were sequentially added at $0{ }^{\circ} \mathrm{C}$ and the reaction mixture was slowly warmed to room temperature and stirred for an additional ca. 16 hours (TLC control). The mixture was then quenched by the addition of water $(60 \mathrm{~mL})$ at $0{ }^{\circ} \mathrm{C}$ and partitioned between diethyl ether and water. The organic phases were combined, washed with saturated aqueous $\mathrm{NaCl}$ solution, dried (anhyd. $\mathrm{Na}_{2} \mathrm{SO}_{4}$ ), filtered and concentrated in vacuo to afford the crude product. Purification by flash chromatography $\left(\mathrm{SiO}_{2}\right.$, gradient elution with $0.5: 99.5$ to $2: 98$ diethyl ether/pentane) afforded the benzyl ether $\mathbf{1 0}(10.34 \mathrm{~g}, 87 \%)$ as a colorless oil.

$[\alpha]_{\mathrm{D}}^{20}+17.8\left(\mathrm{c}=0.20, \mathrm{CHCl}_{3}\right)\left\{\right.$ Lit. $\left.^{6}[\alpha]_{\mathrm{D}}^{23}+13.3\left(\mathrm{c}=1.05, \mathrm{CHCl}_{3}\right)\right\}$.

${ }^{1} \mathbf{H}$ NMR $\left(500 \mathrm{MHz}, \mathrm{CDCl}_{3}\right) \delta$ 7.37-7.33 (m, 4H), 7.29-7.27 (m, 1H), 5.90 (ddt, $J=17.2,10.1,7.1$ $\mathrm{Hz}, 1 \mathrm{H}), 5.11$ (ddd, $J=17.2,3.4,1.5 \mathrm{~Hz}, 1 \mathrm{H}), 5.06$ (app. dt, $J=10.2,1.0 \mathrm{~Hz}, 1 \mathrm{H}), 4.59$ (d, A of AB, $\left.J_{\mathrm{AB}}=11.6 \mathrm{~Hz}, 1 \mathrm{H}\right), 4.51\left(\mathrm{~d}, \mathrm{~B}\right.$ of $\left.\mathrm{AB}, J_{\mathrm{AB}}=11.5 \mathrm{~Hz}, 1 \mathrm{H}\right), 3.21$ (app. q, $\left.J=5.7 \mathrm{~Hz}, 1 \mathrm{H}\right), 2.32$ (app. qt, $J=5.7,1.3 \mathrm{~Hz}, 2 \mathrm{H}), 1.89$ (septet of d, $J=6.8,5.7 \mathrm{~Hz}, 1 \mathrm{H}), 0.96(\mathrm{~d}, J=6.8 \mathrm{~Hz}, 3 \mathrm{H}), 0.94(\mathrm{~d}, J=6.8$ $\mathrm{Hz}, 3 \mathrm{H})$.

IR (neat) 3066 (w), 3030 (w), 2958 (m), 2930 (m), 2869 (m), 1639 (w), 1495 (w), 1464 (w), 1453 (m), 1383 (w), 1363 (w), 1347 (w), 1301 (w), 1206 (w), 1091 (s), 1067 (s), 1027 (m), 994 (m), 910 (m), $732(\mathrm{~s}), 695(\mathrm{~s}) \mathrm{cm}^{-1}$. 
$(3 S, 4 S, 6 S)$-6-(Benzyloxy)-3,7-dimethyloct-1-en-4-ol (11)

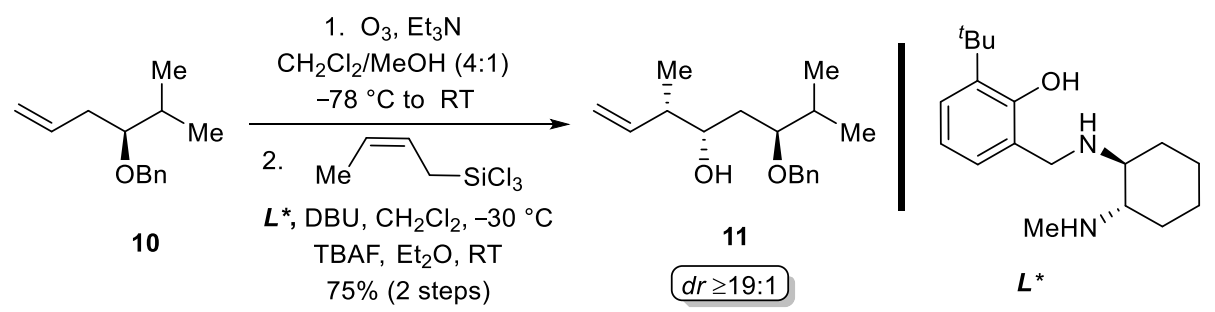

Dry ozone was bubbled through a stirred solution of the olefin $10(2.75 \mathrm{~g}, 13.46 \mathrm{mmol})$ in dichloromethane/methanol ( $85 \mathrm{~mL}, 4: 1)$ at $-78{ }^{\circ} \mathrm{C}$ for $c a .60$ minutes (TLC control). Nitrogen was bubbled through the mixture for $c a .15$ minutes and then triethylamine $(3.63 \mathrm{~mL}, 26.9 \mathrm{mmol}, 2.0$ equiv.) was added via syringe. The reaction mixture was allowed to slowly warm to room temperature and stirred for $c a$. 16 hours under an atmosphere of argon, before being concentrated in vacuo to afford the crude product. Purification by flash chromatography $\left(\mathrm{SiO}_{2}\right.$, gradient elution with 0.5:99.5 to 2:98 diethyl ether/pentane) afforded the aldehyde, which was immediately used in the next step.

Distilled DBU (6.76 mL, $44.4 \mathrm{mmol}, 3.3$ equiv.) was added to a stirred solution of (1S,2S)-2-tertbutyl-6-(\{[2-(methylamino)cyclohexyl]amino $\}$ methyl)phenol $\left(\boldsymbol{L}^{*}\right)(4.30 \mathrm{~g}, 14.80 \mathrm{mmol}, 1.1$ equiv.) in dichloromethane $(40 \mathrm{~mL})$ at $0{ }^{\circ} \mathrm{C}$ under an atmosphere of argon. ${ }^{7}$ (Z)-But-2-en-1-yltrichlorosilane (3.06 g, $16.15 \mathrm{mmol}, 1.2$ equiv.) was then added slowly via syringe and the reaction mixture was allowed to warm to room temperature and stirred for $c a .1$ hour. The resulting solution was then cooled to $-30{ }^{\circ} \mathrm{C}$, and the crude aldehyde obtained from previous step was added in a single portion via syringe as a solution in dichloromethane $(2 \mathrm{~mL})$. The mixture was stirred at the same temperature for an additional ca. 16 hours and then warmed to room temperature and concentrated in vacuo. The residue was dissolved in diethyl ether $(65 \mathrm{~mL})$ and stirred vigorously at room temperature for $c a .20$ minutes. The precipitated salts were then removed via filtration, and the filter cake was washed with diethyl ether. Tetrabutylammonium fluoride ( $14.8 \mathrm{~mL}, 14.8 \mathrm{mmol}, 1.1$ equiv., $1.0 \mathrm{M}$ solution in THF) was added to the filtrate and the mixture was stirred for $c a .2$ hours at room temperature. The reaction was then quenched by the addition of aqueous $1 \mathrm{~N} \mathrm{HCl}$ solution $(50 \mathrm{~mL})$ and partitioned between diethyl ether and water. The organic phases were combined, washed with saturated aqueous $\mathrm{NaHCO}_{3}$ solution, dried (anhyd. $\mathrm{Na}_{2} \mathrm{SO}_{4}$ ), filtered and concentrated in vacuo to afford the crude product. 
Purification by flash chromatography ( $\mathrm{SiO}_{2}$, gradient elution with 5:95 to 8:92 ethyl acetate/pentane) afforded the homoallylic alcohol $11(2.65 \mathrm{~g}, 75 \%)$ as a colorless oil with $\geq 19: 1$ diastereoselectivity. $[\alpha]_{\mathrm{D}}^{23}-38.2\left(\mathrm{c}=1.03, \mathrm{CHCl}_{3}\right)$.

${ }^{1}$ H NMR $\left(500 \mathrm{MHz}, \mathrm{CDCl}_{3}\right) \delta$ 7.36-7.33 (m, 4H), 7.31-7.27 (m, 1H), $5.76(\mathrm{ddd}, J=17.2,10.0,7.7$ $\mathrm{Hz}, 1 \mathrm{H}), 5.05(\mathrm{~d}, J=17.8 \mathrm{~Hz}, 1 \mathrm{H}), 5.05(\mathrm{~d}, J=10.1 \mathrm{~Hz}, 1 \mathrm{H}), 4.58\left(\mathrm{~d}, \mathrm{~A}\right.$ of $\left.\mathrm{AB}, J_{\mathrm{AB}}=11.6 \mathrm{~Hz}, 1 \mathrm{H}\right)$, $4.55\left(\mathrm{~d}, \mathrm{~B}\right.$ of $\left.\mathrm{AB}, J_{\mathrm{AB}}=11.4 \mathrm{~Hz}, 1 \mathrm{H}\right), 3.74-3.68(\mathrm{~m}, 1 \mathrm{H}), 3.47(\mathrm{ddd}, J=8.1,5.9,2.6 \mathrm{~Hz}, 1 \mathrm{H}), 2.53(\mathrm{~d}$, $J=3.8 \mathrm{~Hz}, 1 \mathrm{H}), 2.24$ (app. sextet, $J=6.9 \mathrm{~Hz}, 1 \mathrm{H}), 2.03$ (app. octet, $J=6.7 \mathrm{~Hz}, 1 \mathrm{H}$ ), 1.66 (ddd, $J=$ 14.6, 8.0, 2.2 Hz, 1H), $1.56(\mathrm{ddd}, J=14.6,9.4,2.9 \mathrm{~Hz}, 1 \mathrm{H}), 1.05(\mathrm{~d}, J=6.8 \mathrm{~Hz}, 3 \mathrm{H}), 0.95(\mathrm{~d}, J=6.8$ $\mathrm{Hz}, 3 \mathrm{H}), 0.90(\mathrm{~d}, J=6.8 \mathrm{~Hz}, 3 \mathrm{H})$.

${ }^{13}$ C NMR (125 MHz, $\mathrm{CDCl}_{3}$ ) $\delta 141.20$ (o), 138.66 (e), 128.55 (o), 128.09 (o), 127.81 (o), 115.14 (e), 82.25 (o), 72.14 (e), 71.85 (o), 44.24 (o), 33.25 (e), 30.51 (o), 19.23 (o), 17.74 (o), 15.35 (o).

IR (neat) 3460 (br, w), 3066 (w), 3029 (w), 2959 (m), 2929 (m), 2872 (m), 1640 (w), 1495 (w), 1454 (m), 1416 (w), 1385 (m), 1365 (m), 1352 (w), 1304 (w), 1206 (w), 1177 (w), 1085 (s), 1062 (s), 1028 (s), 995 (m), 962 (m), 911 (s), $844(\mathrm{w}), 733$ (s), 696 (s) $\mathrm{cm}^{-1}$.

HRMS (ESI, $[\mathrm{M}+\mathrm{H}]^{+}$) calcd for $\mathrm{C}_{17} \mathrm{H}_{27} \mathrm{O}_{2}$ 263.2006, found 263.2001.

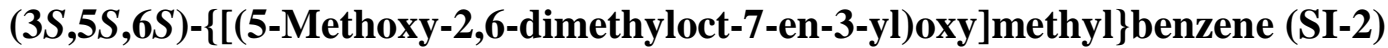
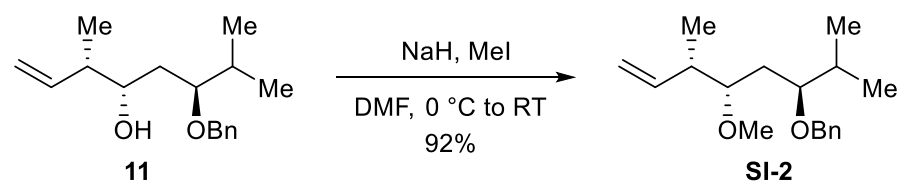

Sodium hydride (1.52 g, $36.2 \mathrm{mmol}, 57 \%$ dispersion in mineral oil, 5.0 equiv., washed with anhyd. hexane three times) was suspended in DMF $(18 \mathrm{~mL})$ and cooled with stirring to $0{ }^{\circ} \mathrm{C}$ under an atmosphere of argon. A solution of the alcohol 11 (1.90 g, $7.24 \mathrm{mmol})$ in $N, N$-dimethylformamide (5 $\mathrm{mL}$ ) was then added dropwise via syringe and the suspension was stirred at $0{ }^{\circ} \mathrm{C}$ for $\mathrm{ca}$. 10 minutes. Iodomethane (2.25 mL, $36.2 \mathrm{mmol}, 5.0$ equiv.) was then added dropwise via syringe and the resulting mixture was allowed to warm to room temperature and stirred for $c a$. 3 hours (TLC control). The reaction was quenched by the addition of water $(15 \mathrm{~mL})$ at $0{ }^{\circ} \mathrm{C}$ and partitioned between diethyl ether and water. The organic phases were combined, washed with water and saturated aqueous $\mathrm{NaCl}$ solution, dried (anhyd. $\mathrm{Na}_{2} \mathrm{SO}_{4}$ ), filtered and concentrated in vacuo to afford the crude product. Purification by flash chromatography $\left(\mathrm{SiO}_{2}\right.$, gradient elution with 2:98 to 3:97 ethyl acetate/pentane) afforded the methyl ether SI-2 (1.841 g, 92\%) as a colorless oil. 
$[\alpha]_{\mathrm{D}}^{23}-74.7\left(\mathrm{c}=0.48, \mathrm{CHCl}_{3}\right)$.

${ }^{1} \mathbf{H}$ NMR $\left(500 \mathrm{MHz}, \mathrm{CDCl}_{3}\right) \delta$ 7.38-7.33 (m, 4H), 7.29-7.28 (m, 1H), 5.85 (ddd, $J=17.3,11.5,7.1$ $\mathrm{Hz}, 1 \mathrm{H}), 5.04(\mathrm{~d}, J=11.4 \mathrm{~Hz}, 1 \mathrm{H}), 5.03(\mathrm{~d}, J=16.9 \mathrm{~Hz}, 1 \mathrm{H}), 4.63\left(\mathrm{~d}, \mathrm{~A}\right.$ of $\left.\mathrm{AB}, J_{\mathrm{AB}}=11.5 \mathrm{~Hz}, 1 \mathrm{H}\right)$, $4.45\left(\mathrm{~d}, \mathrm{~B}\right.$ of $\left.\mathrm{AB}, J_{\mathrm{AB}}=11.5 \mathrm{~Hz}, 1 \mathrm{H}\right), 3.46(\mathrm{ddd}, J=10.0,4.3,2.2 \mathrm{~Hz}, 1 \mathrm{H}), 3.34-3.29(\mathrm{~m}, 1 \mathrm{H}), 3.31$ (s, 3H), 2.57-2.51 (m, 1H), 2.00 (septet of d, $J=6.8,4.8 \mathrm{~Hz}, 1 \mathrm{H}), 1.50$ (ddd, $J=14.3,10.3,2.3 \mathrm{~Hz}$, $1 \mathrm{H}), 1.41$ (ddd, $J=14.3,10.3,2.2 \mathrm{~Hz}, 1 \mathrm{H}), 1.01$ (d, $J=6.9 \mathrm{~Hz}, 3 \mathrm{H}), 0.93$ (d, $J=6.3 \mathrm{~Hz}, 3 \mathrm{H}), 0.92$ (d, $J=6.4 \mathrm{~Hz}, 3 \mathrm{H})$.

${ }^{13}$ C NMR (125 MHz, $\mathrm{CDCl}_{3}$ ) $\delta 140.53$ (o), 139.40 (e), 128.44 (o), 127.87 (o), 127.51 (o), 114.65 (e), 81.60 (o), 80.67 (o), 71.99 (e), 57.47 (o), 39.76 (o), 32.16 (e), 30.74 (o), 18.66 (o), 17.32 (o), 15.41 (o).

IR (neat) 3066 (w), 3029 (w), 2960 (m), 2930 (m), 2874 (m), 2822 (w), 1639 (w), 1495 (w), 1454 (m), 1378 (w), 1363 (m), 1191 (w), 1140 (w), 1094 (vs), 1068 (s), 1028 (m), 997 (w), 912 (m), 828 (w), $734(\mathrm{~m}), 697(\mathrm{~m}) \mathrm{cm}^{-1}$.

HRMS (ESI, $[\mathrm{M}+\mathrm{H}]^{+}$) calcd for $\mathrm{C}_{18} \mathrm{H}_{29} \mathrm{O}_{2} 277.2162$, found 277.2150.

(3S,5S,6S)-5-Methoxy-2,6-dimethyloct-7-en-3-ol (SI-3):

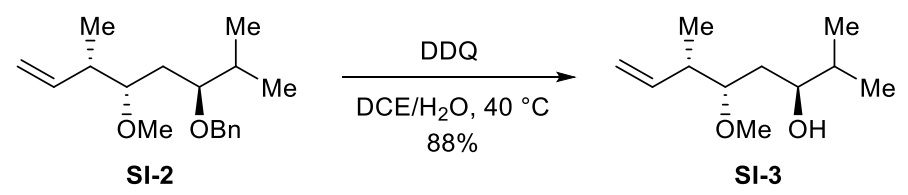

Dichloro-5,6-dicyano-1,4-benzoquinone (DDQ) (6.07 g, $26.8 \mathrm{mmol}, 1.3$ equiv.) was added to a stirred solution of the benzyl ether SI-2 $(5.69 \mathrm{~g}, 20.59 \mathrm{mmol})$ in 1,2-dichloroethane (DCE)/water (150 mL, 9:1) at room temperature under an atmosphere of argon. The resulting mixture was warmed to $40{ }^{\circ} \mathrm{C}$ and stirred for $c a$. 16 hours. The mixture was then cooled to room temperature and quenched by the addition of saturated aqueous $\mathrm{NaHCO}_{3}$ solution $(200 \mathrm{~mL})$. The reaction mixture was partitioned between dichloromethane and water and the organic phases were combined, washed with saturated aqueous $\mathrm{NaCl}$ solution, dried (anhyd. $\mathrm{Na}_{2} \mathrm{SO}_{4}$ ), filtered and concentrated in vacuo to afford the crude product. Purification by flash chromatography $\left(\mathrm{SiO}_{2}\right.$, gradient elution with 10:90 to 50:50 diethyl ether/pentane) afforded the secondary alcohol SI-3 (3.37 g, 88\%) as a colorless oil. $[\alpha]_{\mathrm{D}}^{24}-37.5\left(\mathrm{c}=0.49, \mathrm{CHCl}_{3}\right)$. 
${ }^{1} \mathbf{H}$ NMR $\left(500 \mathrm{MHz}, \mathrm{CDCl}_{3}\right) \delta 5.75(\mathrm{ddd}, J=17.3,10.0,7.3 \mathrm{~Hz}, 1 \mathrm{H}), 5.07-5.01(\mathrm{~m}, 2 \mathrm{H}), 3.60$ (ddd, $J$ $=8.5,5.7,3.3 \mathrm{~Hz}, 1 \mathrm{H}), 3.41(\mathrm{~s}, 3 \mathrm{H}), 3.31(\mathrm{td}, J=6.6,3.9 \mathrm{~Hz}, 1 \mathrm{H}), 2.56$ (app. sextet, $J=6.9 \mathrm{~Hz}, 1 \mathrm{H}$ ), 2.51 (br. s, 1H), 1.62 (app. octet, $J=6.7 \mathrm{~Hz}, 1 \mathrm{H}), 1.57-1.51$ (m, 2H), 1.04 (d, $J=6.8 \mathrm{~Hz}, 3 \mathrm{H}), 0.92$ (d, $J=6.7 \mathrm{~Hz}, 3 \mathrm{H}), 0.88(\mathrm{~d}, J=6.8 \mathrm{~Hz}, 3 \mathrm{H})$.

${ }^{13}$ C NMR (125 MHz, $\mathrm{CDCl}_{3}$ ) $\delta 140.35$ (o), 115.05 (e), 83.24 (o), 73.62 (o), 57.93 (o), 40.32 (o), 34.16 (o), 33.62 (e), 18.70 (o), 18.02 (o), 16.32 (o).

IR (neat) 3465 (br, m), 3077 (w), 2959 (vs), 2932 (s), 2876 (m), 2827 (w), 1640 (w), 1463 (m), 1418 (w), 1369 (m), 1272 (w), 1180 (w), 1143 (w), 1089 (s), 1035 (m), 999 (m), 912 (m), 829 (w), $710(w)$, $683(\mathrm{w}) \mathrm{cm}^{-1}$.

HRMS (ESI, $[\mathrm{M}+\mathrm{H}]^{+}$) calcd for $\mathrm{C}_{11} \mathrm{H}_{23} \mathrm{O}_{2}$ 187.1693, found 187.1683.

(3S,5S,6S)-tert-Butyl[(5-methoxy-2,6-dimethyloct-7-en-3-yl)oxy]dimethylsilane (12)

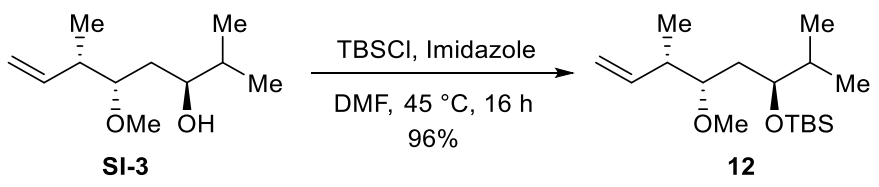

Imidazole (3.11 g, $46.1 \mathrm{mmol}, 2.0$ equiv.) and tert-butyldimethylsilyl chloride (5.21g, $34.5 \mathrm{mmol}, 1.5$ equiv.) were sequentially added to a stirred solution of the secondary alcohol SI-3 (4.29 g, 23.03 $\mathrm{mmol})$ in anhydrous DMF $(46 \mathrm{~mL})$ at room temperature under an atmosphere of argon. The resulting mixture was warmed to $45{ }^{\circ} \mathrm{C}$ and stirred for $c a$. 16 hours. The solution was then cooled to room temperature and quenched by the addition of water $(10 \mathrm{~mL})$. The reaction mixture was partitioned between diethyl ether and water and the organic phases were combined, washed with saturated aqueous $\mathrm{NaCl}$ solution, dried (anhyd. $\mathrm{Na}_{2} \mathrm{SO}_{4}$ ), filtered and concentrated in vacuo to afford the crude product. Purification by flash chromatography $\left(\mathrm{SiO}_{2}\right.$, gradient elution with 2:98 to 4:96 diethyl ether/pentane) afforded the title compound 12 (6.64 g; 96\%) as a colorless oil. $[\alpha]_{\mathrm{D}}^{20}-37.5\left(\mathrm{c}=0.49, \mathrm{CHCl}_{3}\right)$.

${ }^{1} \mathbf{H}$ NMR $\left(500 \mathrm{MHz}, \mathrm{CDCl}_{3}\right) \delta 5.84(\mathrm{ddd}, J=16.8,10.4,6.4 \mathrm{~Hz}, 1 \mathrm{H}), 5.04$ (app. dt, $J=17.3,1.4 \mathrm{~Hz}$, 1H), 5.03 (app. dt, $J=10.6,1.5 \mathrm{~Hz}, 1 \mathrm{H}$ ), 3.72 (dt, $J=8.0,3.6 \mathrm{~Hz}, 1 \mathrm{H}$ ), 3.36 (s, 3H), 3.26 (dt, $J=7.6$, $4.3 \mathrm{~Hz}, 1 \mathrm{H}), 2.62-2.55(\mathrm{~m}, 1 \mathrm{H}), 1.76$ (septet of d, $J=6.8,3.4 \mathrm{~Hz}, 1 \mathrm{H}), 1.38-1.30(\mathrm{~m}, 2 \mathrm{H}), 0.99(\mathrm{~d}, J=$ $6.9 \mathrm{~Hz}, 3 \mathrm{H}), 0.90$ (s, 9H), 0.85 (d, $J=6.9 \mathrm{~Hz}, 3 \mathrm{H}), 0.83$ (d, $J=7.0 \mathrm{~Hz}, 3 \mathrm{H}), 0.07$ (s, 3H), 0.05 (s, 3H). ${ }^{13}$ C NMR (125 MHz, $\mathrm{CDCl}_{3}$ ) $\delta 140.35$ (o), 114.63 (e), 81.59 (o), 73.49 (o), 56.79 (o), 38.94 (o), 34.04 (o), 33.06 (e), 26.15 (o), 18.33 (e), 18.11 (o), 16.52 (o), 15.38 (o), -3.82 (o), -4.31 (o). 
IR (neat) 2957 (m), 2930 (m), $2884(\mathrm{w}), 2857$ (m), 1639 (w), 1462 (w), 1385 (w), 1370 (w), 1251 (m), 1188 (w), 1142 (w), 1094 (m), 1057 (s), 1003 (m), 953 (w), 911 (m), 863 (m), 832 (s), 808 (m), 771 (vs), $736(\mathrm{~m}), 709(\mathrm{w}), 663(\mathrm{~m}) \mathrm{cm}^{-1}$.

HRMS (ESI, $[\mathrm{M}+\mathrm{H}]^{+}$) calcd for $\mathrm{C}_{17} \mathrm{H}_{37} \mathrm{O}_{2} \mathrm{Si} 301.2557$, found 301.2556.

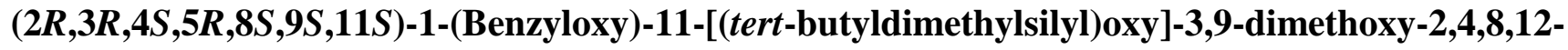
tetramethyltridecan-5-ol (13)

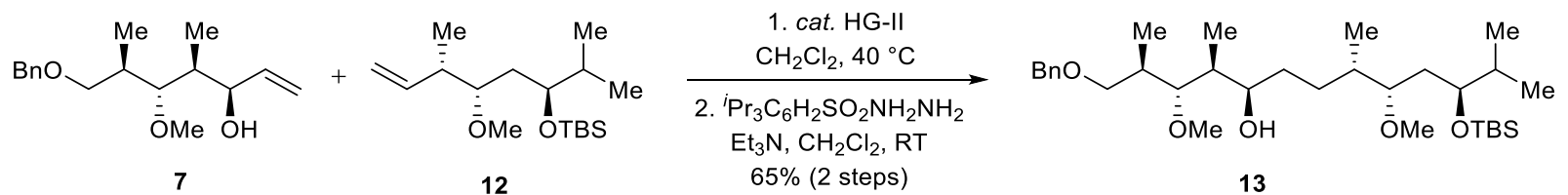

Hoveyda-Grubbs second-generation catalyst (126 mg, $0.201 \mathrm{mmol}, 0.1$ equiv.) was added to a stirred solution of the allylic alcohol $7(0.56 \mathrm{~g}, 2.01 \mathrm{mmol})$ and the homoallylic ether $12(1.511 \mathrm{~g}, 5.03$ mmol, 2.5 equiv.) in degassed dichloromethane $(59 \mathrm{~mL})$ under an atmosphere of argon. The solution was gently refluxed for $c a$. 6 hours, cooled to room temperature and then concentrated in vacuo to afford the crude product. Purification by flash chromatography $\left(\mathrm{SiO}_{2}\right.$, gradient elution with 2:98 to 10:90 ethyl acetate/pentane) afforded the cross-coupled olefin with catalyst residue, which was carried forward to the next step.

2,4,6-Triisopropylbenzenesulfonohydrazide ${ }^{8}(6.00 \mathrm{~g}, 20.11 \mathrm{mmol}, 10.0$ equiv.) was added to a stirred solution of the crude olefin in dichloromethane $(42 \mathrm{~mL})$ under an atmosphere of argon. Anhydrous triethylamine (8.68 mL, $64.4 \mathrm{mmol}, 32$ equiv.) was added via syringe and the solution was stirred for ca. 16 hours at room temperature. The reaction was quenched by the addition of saturated aqueous $\mathrm{NaHCO}_{3}$ solution $(150 \mathrm{~mL})$ and partitioned between hexanes/diethyl ether (1:1) and water. The organic phases were combined, dried (anhyd. $\mathrm{Na}_{2} \mathrm{SO}_{4}$ ), filtered and concentrated in vacuo to afford the crude product. Purification by flash chromatography $\left(\mathrm{SiO}_{2}\right.$, gradient elution with 2:98:0.5 to 8:92:0.5 pentane/ethyl acetate/triethylamine) afforded the title compound $\mathbf{1 3}(0.723 \mathrm{~g}, 65 \%)$ as a colorless oil.

$[\alpha]_{\mathrm{D}}^{21}-6.9\left(\mathrm{c}=0.18, \mathrm{CHCl}_{3}\right)$.

${ }^{1}$ H NMR (500 MHz, $\left.\mathrm{CDCl}_{3}\right) \delta$ 7.36-7.27 (m, 5H), 4.51 (s, 2H), 3.90 (app. t, $\left.J=6.4 \mathrm{~Hz}, 1 \mathrm{H}\right), 3.69(\mathrm{dt}$, $J=8.5,3.3 \mathrm{~Hz}, 1 \mathrm{H}), 3.56(\mathrm{dd}, J=8.9,5.3 \mathrm{~Hz}, 1 \mathrm{H}), 3.51(\mathrm{dd}, J=9.0,3.6 \mathrm{~Hz}, 1 \mathrm{H}), 3.48(\mathrm{~s}, 1 \mathrm{H}), 3.45$ (s, 3H), 3.32 (s, 3H), $3.21(\mathrm{dd}, J=8.6,3.1 \mathrm{~Hz}, 1 \mathrm{H}), 3.22-3.18(\mathrm{~m}, 1 \mathrm{H}), 2.10-2.04(\mathrm{~m}, 1 \mathrm{H}), 1.80-1.70$ 
(m, 3H), 1.62-1.55 (m, 1H), 1.49-1.30 (m, 4H), $1.05(\mathrm{~d}, J=7.1 \mathrm{~Hz}, 3 \mathrm{H}), 0.98-0.97(\mathrm{~m}, 1 \mathrm{H}), 0.97(\mathrm{~d}, J$ $=6.9 \mathrm{~Hz}, 3 \mathrm{H}), 0.89(\mathrm{~s}, 9 \mathrm{H}), 0.86(\mathrm{~d}, J=6.8 \mathrm{~Hz}, 3 \mathrm{H}), 0.86(\mathrm{~d}, J=6.8 \mathrm{~Hz}, 3 \mathrm{H}), 0.83(\mathrm{~d}, J=6.9 \mathrm{~Hz}$, $3 \mathrm{H}), 0.06$ (s, 3H), 0.05 (s, 3H).

${ }^{13}$ C NMR (125 MHz, $\mathrm{CDCl}_{3}$ ) $\delta 138.76$ (e), 128.46 (o), 127.70 (o), 127.64 (o), 89.21 (o), 81.90 (o), 73.67 (o), 73.23 (e), 72.45 (e), 71.17 (o), 61.91 (o), 57.12 (o), 37.11 (o), 36.84 (o), 34.99 (o), 33.77 (o), 32.97 (e), 27.91 (e), 26.14 (o), 18.31 (e), 17.77 (o), 16.91 (o), 15.46 (o), 15.19 (o), 11.50 (o), 3.89 (o), -4.25 (o).

IR (neat) 3511 (br, w), 2955 (m), 2930 (m), 2882 (m), 2855 (m), 1459 (m), 1408 (w), 1362 (m), 1316 (w), 1251 (m), 1192 (w), 1086 (vs), 1006 (w), 970 (m), 956 (m), 937 (w), 834 (s), 772 (s), 735 (m), $697(\mathrm{~m}), 664(\mathrm{w}) \mathrm{cm}^{-1}$.

HRMS (ESI, $[\mathrm{M}+\mathrm{H}]^{+}$) calcd for $\mathrm{C}_{32} \mathrm{H}_{61} \mathrm{O}_{5} \mathrm{Si} 553.4283$, found 553.4260.

(2R,3R,4S,5R,8S,9S,11S)-1-(Benzyloxy)-11-[(tert-butyldimethylsilyl)oxy]-3,9-dimethoxy-2,4,8,12tetramethyltridecan-5-yl $(R)$-tetrahydrofuran-2-carboxylate (SI-4)

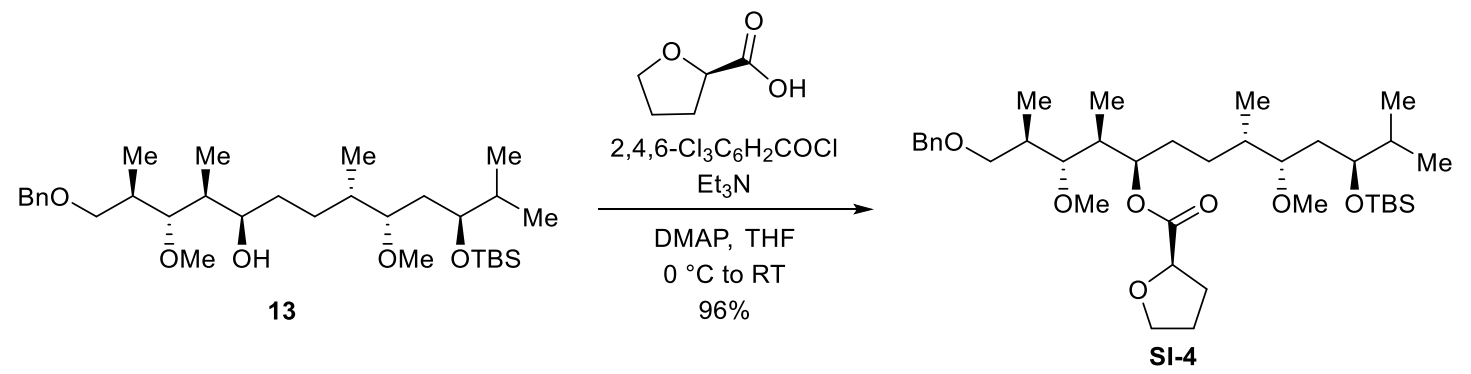

Anhydrous triethylamine (0.325 mL, $2.33 \mathrm{mmol}, 3.0$ equiv.) and 2,4,6-trichlorobenzoyl chloride $(0.365 \mathrm{~mL}, 2.33 \mathrm{mmol}, 3.0$ equiv.) were sequentially added to a stirred solution of $(R)$-(+)-tetrahydro2-furoic acid (0.224 g, $2.33 \mathrm{mmol}, 3.0$ equiv.) in THF (5 mL) at room temperature under an atmosphere of argon and the mixture was stirred for $c a .2$ hours. The precipitated salts were removed using a syringe tip filter, and then the mixed anhydride solution was added to a stirred solution of the secondary alcohol 13 (0.43 g, $0.778 \mathrm{mmol})$ and 4-dimethylaminopyridine (190 mg, $1.56 \mathrm{mmol}, 2.0$ equiv. $)$ in $\mathrm{THF}(6 \mathrm{~mL})$ at $0{ }^{\circ} \mathrm{C}$ under an atmosphere of argon. The resulting mixture was then warmed to room temperature and stirred for $c a$. 16 hours (TLC control). The reaction was quenched by the addition of saturated aqueous $\mathrm{NaHCO}_{3}$ solution $(2 \mathrm{~mL})$ and partitioned between diethyl ether and water. The organic phases were combined, dried (anhyd. $\mathrm{Na}_{2} \mathrm{SO}_{4}$ ), filtered and concentrated in vacuo 
to afford the crude product. Purification by flash chromatography $\left(\mathrm{SiO}_{2}\right.$, gradient elution with 2.5: 97.5 to 10:90 ethyl acetate/pentane) afforded the ester SI-4 (0.486 g, 96\%) as a colorless oil. $[\alpha]_{\mathrm{D}}^{20}-39.1\left(\mathrm{c}=0.5, \mathrm{CHCl}_{3}\right)$

${ }^{1} \mathbf{H}$ NMR $\left(500 \mathrm{MHz}, \mathrm{CDCl}_{3}\right) \delta 7.35-7.31(\mathrm{~m}, 4 \mathrm{H}), 7.29-7.24(\mathrm{~m}, 1 \mathrm{H}), 5.23(\mathrm{td}, J=7.0,1.8 \mathrm{~Hz}, 1 \mathrm{H})$, $4.50\left(\mathrm{~d}, \mathrm{~A}\right.$ of $\left.\mathrm{AB}, J_{\mathrm{AB}}=12.0 \mathrm{~Hz}, 1 \mathrm{H}\right), 4.46\left(\mathrm{~d}, \mathrm{~B}\right.$ of $\left.\mathrm{AB}, J_{\mathrm{AB}}=12.0 \mathrm{~Hz}, 1 \mathrm{H}\right), 4.44(\mathrm{dd}, J=8.3,5.2 \mathrm{~Hz}$, 1H), 4.01 (app. q, $J=7.3,1 \mathrm{H}), 3.91$ (dt, $J=7.6,6.3 \mathrm{~Hz}, 1 \mathrm{H}), 3.67$ (dt, $J=8.4,3.4 \mathrm{~Hz}, 1 \mathrm{H}), 3.55$ (dd, $J=9.2,5.0 \mathrm{~Hz}, 1 \mathrm{H}), 3.38(\mathrm{~s}, 3 \mathrm{H}), 3.38-3.35(\mathrm{~m}, 1 \mathrm{H}), 3.30(\mathrm{~s}, 3 \mathrm{H}), 3.18(\mathrm{dt}, J=8.7,3.4 \mathrm{~Hz}, 1 \mathrm{H}), 2.90$ $(\mathrm{dd}, J=8.4,3.7 \mathrm{~Hz}, 1 \mathrm{H}), 2.21(\mathrm{dtd}, J=12.5,8.3,6.9 \mathrm{~Hz}, 1 \mathrm{H}), 2.14-2.08(\mathrm{~m}, 1 \mathrm{H}), 2.07-2.03(\mathrm{~m}, 1 \mathrm{H})$, 2.02-1.86 (m, 2H), 1.85-1.80 (m, 1H), 1.80-1.71 (m, 2H), 1.66-1.53 (m, 2H), 1.48-1.41 (m, 1H), 1.37$1.26(\mathrm{~m}, 2 \mathrm{H}), 1.07$ (d, J = 7.0 Hz, 3H), 1.04-0.96 (m, 1H), 0.93 (d, J= 7.0 Hz, 3H), 0.89 (s, 9H), 0.85 $(\mathrm{d}, J=6.9 \mathrm{~Hz}, 3 \mathrm{H}), 0.84(\mathrm{~d}, J=7.0 \mathrm{~Hz}, 3 \mathrm{H}), 0.82$ (d, $J=7.0 \mathrm{~Hz}, 3 \mathrm{H}), 0.05(\mathrm{~s}, 3 \mathrm{H}), 0.04(\mathrm{~s}, 3 \mathrm{H})$.

${ }^{13}$ C NMR (125 MHz, $\mathrm{CDCl}_{3}$ ) $\delta 173.09$ (e), 138.88 (e), 128.42 (o), 127.56 (o), 127.53 (o), 85.83 (o), 81.73 (o), 77.23 (o), 74.07 (o), 73.70 (o), 73.22 (e), 72.02 (e), 69.30 (e), 61.39 (o), 57.03 (o), 38.56 (o), 36.06 (o), 34.31 (o), 33.81 (o), 32.77 (e), 30.61 (e), 30.31 (e), 27.11 (e), 26.14 (o), 25.30 (e), 18.29 (e), 17.81 (o), 16.85 (o), 16.23 (o), 15.47 (o), 10.67 (o), -3.88 (o), -4.26 (o).

IR (neat) 2956 (m), 2929 (m), 2877 (m), 2857 (m), 1729 (m), 1494 (w), 1458 (m), 1382 (m), 1367 (w), 1273 (w), 1251 (m), 1198 (m), 1086 (s), 1005 (m), 972 (m), 937 (m), 833 (s), 772 (s), 734 (m), $697(\mathrm{~m}), 664(\mathrm{w}) \mathrm{cm}^{-1}$.

HRMS (ESI, $[\mathrm{M}+\mathrm{Na}]^{+}$) calcd for $\mathrm{C}_{37} \mathrm{H}_{66} \mathrm{NaO}_{7} \mathrm{Si} 673.4470$, found 673.4487.

(2R,3R,4S,5R,8S,9S,11S)-11-[(tert-Butyldimethylsilyl)oxy]-1-hydroxy-3,9-dimethoxy-2,4,8,12tetramethyltridecan-5-yl $(R)$-tetrahydrofuran-2-carboxylate (14)
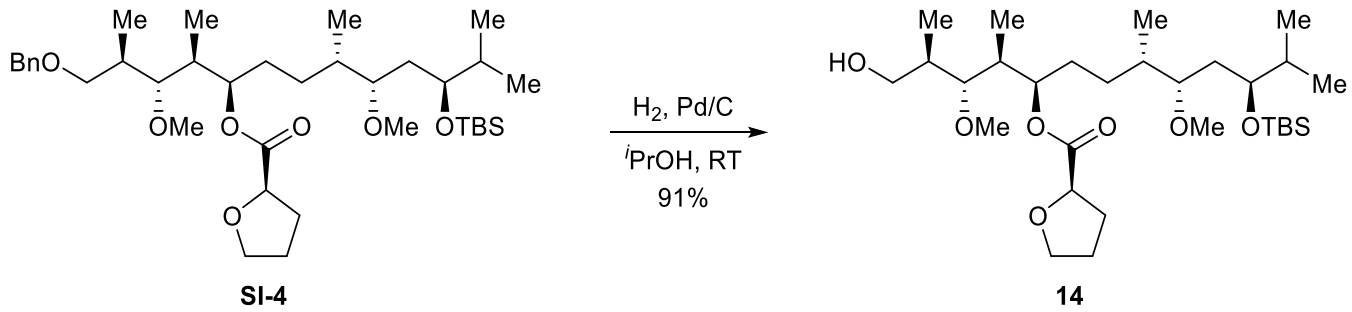

$10 \%$ Palladium on charcoal ( $234 \mathrm{mg}, 0.18$ equiv.) was added to a stirred solution of the benzyl ether S4 (0.794 g, $1.22 \mathrm{mmol}, 1.0$ equiv.) in isopropanol $(11 \mathrm{~mL})$ at room temperature. The flask was evacuated, backfilled with hydrogen and stirred for $c a$. 16 hours under an atmosphere of hydrogen (balloon). The mixture was filtered through a pad of Celite ${ }^{\circledR}$ to remove the catalyst, and the filter cake 
was washed with ethyl acetate. The filtrate was concentrated in vacuo to afford the crude product, which was purified by flash chromatography $\left(\mathrm{SiO}_{2}\right.$, gradient elution with 10:90 to 25:75 ethyl acetate/pentane) to afford the primary alcohol $14(0.624 \mathrm{~g}, 91 \%)$ as a colorless oil.

$[\alpha]_{\mathrm{D}}^{20}-27.7\left(\mathrm{c}=1, \mathrm{CHCl}_{3}\right)$

${ }^{1}$ H NMR $\left(500 \mathrm{MHz}, \mathrm{CDCl}_{3}\right) \delta 5.24(\mathrm{td}, J=6.9,1.8 \mathrm{~Hz}, 1 \mathrm{H}), 4.45(\mathrm{dd}, J=8.3,5.1 \mathrm{~Hz}, 1 \mathrm{H}), 4.02$ (app. q, $J=7.3 \mathrm{~Hz}, 1 \mathrm{H}), 3.93$ (app. q, $J=7.1 \mathrm{~Hz}, 1 \mathrm{H}), 3.81(\mathrm{dt}, J=11.0,3.3 \mathrm{~Hz}, 1 \mathrm{H}), 3.68(\mathrm{dt}, J=7.6,3.6$ $\mathrm{Hz}, 1 \mathrm{H}), 3.56$ (ddd, $J=11.0,6.7,4.5 \mathrm{~Hz}, 1 \mathrm{H}), 3.46$ (s, 3H), 3.31 (s, 3H), 3.19 (dt, $J=8.4,3.4 \mathrm{~Hz}$, $1 \mathrm{H}), 2.96(\mathrm{dd}, J=8.6,3.2 \mathrm{~Hz}, 1 \mathrm{H}), 2.72(\mathrm{dd}, J=7.0,3.7 \mathrm{~Hz}, 1 \mathrm{H}), 2.28-2.21(\mathrm{~m}, 1 \mathrm{H}), 2.05-1.99(\mathrm{~m}$, 1H), 1.98-1.88 (m, 4H), 1.81-1.72 (m, 2H), 1.68-1.62 (m, 2H), 1.50-1.43 (m, 1H), 1.36-1.27 (m, 2H), $1.14(\mathrm{~d}, J=7.1 \mathrm{~Hz}, 3 \mathrm{H}), 1.04-0.96(\mathrm{~m}, 1 \mathrm{H}), 0.92$, (d, $J=7.1 \mathrm{~Hz}, 3 \mathrm{H}), 0.89(\mathrm{~s}, 9 \mathrm{H}), 0.85(\mathrm{~d}, J=6.9$ $\mathrm{Hz}, 6 \mathrm{H}), 0.83$ (d, J = 7.1 Hz, 3H), 0.06 (s, 3H), 0.05 (s, 3H).

${ }^{13}$ C NMR (125 MHz, $\mathrm{CDCl}_{3}$ ) $\delta 173.15$ (e), 88.60 (o), 81.76 (o), 77.26 (o), 74.01 (o), 73.71 (o), 69.33 (e), 64.78 (e), 61.92 (o), 57.03 (o), 39.07 (o), 36.42 (o), 34.19 (o), 33.84 (o), 32.69 (e), 30.56 (e), 30.39 (e), 26.97 (e), 26.13 (o), 25.35 (e), 18.28 (e), 17.84 (o), 16.79 (o), 16.26 (o), 15.53 (o), 10.62 (o), -3.89 (o), -4.27 (o).

IR (neat) 3486 (br, w), 2956 (m), 2929 (m), 2878 (m), 2858 (m), 1730 (m), 1461 (m), 1383 (m), 1372 (m), $1274(\mathrm{~m}), 1251$ (m), $1198(\mathrm{~m}), 1146(\mathrm{~m}), 1084(\mathrm{~s}), 975(\mathrm{~m}), 936(\mathrm{~m}), 917$ (m), $859(\mathrm{~m}), 833(\mathrm{~s})$, $772(\mathrm{~s}), 732(\mathrm{~m}), 662(\mathrm{~m}) \mathrm{cm}^{-1}$.

HRMS (ESI, $[\mathrm{M}+\mathrm{H}]^{+}$) calcd for $\mathrm{C}_{30} \mathrm{H}_{61} \mathrm{O}_{7} \mathrm{Si} 561.4181$, found 561.4158.

$(3 R, 4 R, 5 S, 6 R, 9 S, 10 S, 12 S, E)-12-H y d r o x y-1-i o d o-4,10$-dimethoxy-3,5,9,13-tetramethyltetradec-1en-6-yl $(R)$-tetrahydrofuran-2-carboxylate (15)
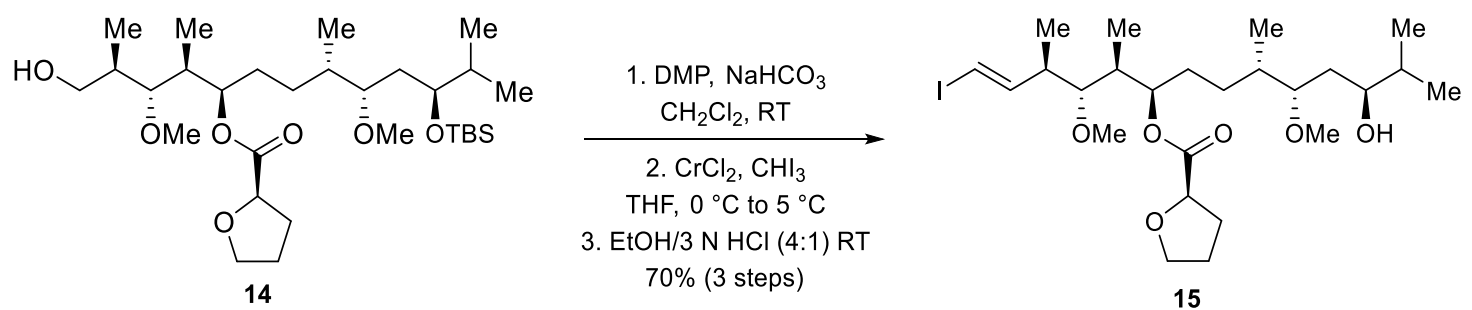

Sodium bicarbonate (336 mg, $3.99 \mathrm{mmol}, 11.2$ equiv.) and Dess-Martin periodinane (333 mg, 0.784 mmol, 2.2 equiv.) were sequentially added to a stirred solution of the primary alcohol $14(0.200 \mathrm{~g}$, $0.357 \mathrm{mmol})$ in degassed dichloromethane $(3.5 \mathrm{~mL})$ at room temperature under an atmosphere of argon. The reaction mixture was stirred for $c a$. 2 hours (TLC control) and quenched by the addition 
of a 1:1 mixture of saturated aqueous $\mathrm{NaHCO}_{3}$ and $\mathrm{Na}_{2} \mathrm{~S}_{2} \mathrm{O}_{3}$ solutions. The mixture was then partitioned between dichloromethane and water and the organic phases were combined, washed with saturated aqueous $\mathrm{NaCl}$ solution, dried (anhyd. $\mathrm{Na}_{2} \mathrm{SO}_{4}$ ), filtered and concentrated in vacuo to afford the crude aldehyde that was used directly in the next step without further purification.

Anhydrous THF (9 mL) was added to a mixture of the crude aldehyde and iodoform $(0.827 \mathrm{~g}, 2.10$ mmol, 5.9 equiv.) under an atmosphere of argon. The solution was then transferred via syringe to a Schlenk flask containing anhydrous chromium(II) chloride $(0.731 \mathrm{~g}, 5.95 \mathrm{mmol}, 16.7$ equiv. $)$ at $0{ }^{\circ} \mathrm{C}$ under an atmosphere of argon. The reaction mixture was vigorously stirred for $c a$. 2 hours, during which time the temperature was allowed to increase to $5^{\circ} \mathrm{C}$ (TLC control). The reaction was then quenched by the addition of ice-cold water and partitioned with ethyl acetate/hexanes (5:95). The organic phases were combined, washed with saturated aqueous $\mathrm{NaCl}$ solution, dried (anhyd. $\mathrm{Na}_{2} \mathrm{SO}_{4}$ ), filtered and concentrated in vacuo to provide the crude vinyl iodide. ${ }^{9}$

The crude vinyl iodide was dissolved in ethanol/aqueous $3 \mathrm{~N} \mathrm{HCl}$ solution (4:1) and stirred at room temperature for $c a .90$ minutes (TLC control). The reaction was quenched by the careful addition of saturated aqueous $\mathrm{NaHCO}_{3}$ solution and partitioned between ethyl acetate and water. The organic phases were combined, washed with saturated aqueous $\mathrm{NaCl}$ solution, dried (anhyd. $\mathrm{Na}_{2} \mathrm{SO}_{4}$ ), filtered and concentrated in vacuo to provide the crude product. Purification by flash chromatography $\left(\mathrm{SiO}_{2}\right.$, gradient elution with 10:90 to 25:75 ethyl acetate/pentane) afforded the vinyl iodide $\mathbf{1 5}(0.142 \mathrm{~g}, 70 \%)$ as a yellowish oil over three steps.

$[\alpha]_{\mathrm{D}}^{20}-23.2\left(\mathrm{c}=0.75, \mathrm{CHCl}_{3}\right)$

${ }^{1}$ H NMR $\left(500 \mathrm{MHz}, \mathrm{CDCl}_{3}\right) \delta 6.54(\mathrm{dd}, J=14.6,8.9 \mathrm{~Hz}, 1 \mathrm{H}), 6.02(\mathrm{dd}, J=14.5,0.6 \mathrm{~Hz}, 1 \mathrm{H}), 5.21$ $(\mathrm{td}, J=7.0,1.6 \mathrm{~Hz}, 1 \mathrm{H}), 4.42(\mathrm{dd}, J=8.3,5.0 \mathrm{~Hz}, 1 \mathrm{H}), 3.99$ (app. q, $J=7.3 \mathrm{~Hz}, 1 \mathrm{H}), 3.93-3.88(\mathrm{~m}$, 1H), 3.54-3.50 (m, 1H), $3.39(\mathrm{~s}, 3 \mathrm{H}), 3.36(\mathrm{~s}, 3 \mathrm{H}), 3.28(\mathrm{ddd}, J=8.3,5.0,3.2 \mathrm{~Hz}, 1 \mathrm{H}), 2.74(\mathrm{dd}, J=$ 9.4, $2.6 \mathrm{~Hz}, 1 \mathrm{H}), 2.47$ (dqd, $J=8.9,6.9,2.1 \mathrm{~Hz}, 1 \mathrm{H}), 2.32$ (br. s, 1H), 2.23 (dtd, $J=14.4,8.2,6.4 \mathrm{~Hz}$, $1 \mathrm{H}), 2.01-1.89(\mathrm{~m}, 3 \mathrm{H}), 1.82-1.75(\mathrm{~m}, 1 \mathrm{H}), 1.65-1.58(\mathrm{~m}, 3 \mathrm{H}), 1.57-1.40(\mathrm{~m}, 4 \mathrm{H}), 1.10(\mathrm{~d}, J=7.0 \mathrm{~Hz}$, $3 \mathrm{H}), 1.03-0.96(\mathrm{~m}, 1 \mathrm{H}), 0.93(\mathrm{~d}, J=6.7 \mathrm{~Hz}, 3 \mathrm{H}), 0.89(\mathrm{~d}, J=6.8 \mathrm{~Hz}, 3 \mathrm{H}), 0.88(\mathrm{~d}, J=6.8 \mathrm{~Hz}, 3 \mathrm{H})$, $0.83(\mathrm{~d}, J=7.0 \mathrm{~Hz}, 3 \mathrm{H})$.

${ }^{13}$ C NMR (125 MHz, $\mathrm{CDCl}_{3}$ ) $\delta 173.17$ (e), 147.55 (o), 86.07 (o), 83.08 (o), 77.23 (o), 75.21 (o), 74.06 (o), 73.95 (o), 69.34 (e), 61.64 (o), 57.85 (o), 43.36 (o), 39.35 (o), 34.79 (o), 34.07 (o), 33.56 (e), 30.42 (e), 30.27 (e), 27.48 (e), 25.36 (e), 18.90 (o), 17.98 (o), 17.92 (o), 15.68 (o), 9.96 (o). 
IR (neat) 3488 (br, w), 2956 (m), 2930 (m), 2873 (m), 2830 (w), 1728 (m), 1600 (w), 1459 (m), 1381 (m), 1366 (w), 1272 (m), 1200 (m), 1178 (m), 1149 (m), 1085 (s), 1035 (m), 966 (m), 908 (m), 868 (w), $792(\mathrm{w}), 735(\mathrm{~m}), 698(\mathrm{w}) \mathrm{cm}^{-1}$.

HRMS (ESI, $[\mathrm{M}+\mathrm{H}]^{+}$) calcd for $\mathrm{C}_{25} \mathrm{H}_{46} \mathrm{IO}_{6} 569.2334$, found 569.2319.

\section{$(3 R, 4 R, 5 S, 6 R, 9 S, 10 S, 12 S, E)-1-(N$-Ethylformamido)-12-hydroxy-4,10-dimethoxy-3,5,9,13-} tetramethyltetradec-1-en-6-yl $(R)$-tetrahydrofuran-2-carboxylate (SI-5)

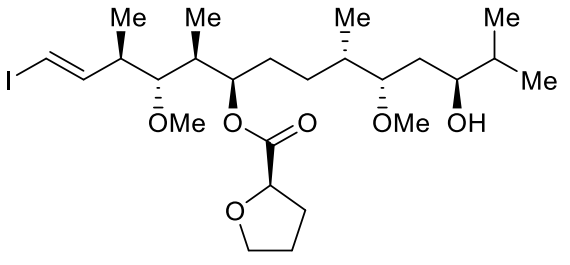

15

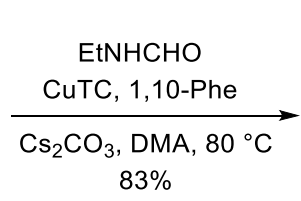

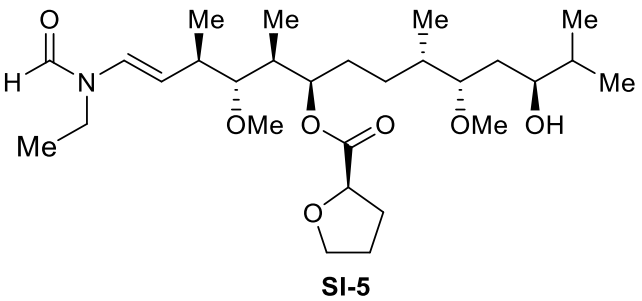

$N$-Ethylformamide (0.541 mL, $7.04 \mathrm{mmol}, 100$ equiv.), cesium carbonate (41.3 mg, $0.127 \mathrm{mmol}, 1.8$ equiv.), 1,10-phenanthroline (50.7 mg, $0.281 \mathrm{mmol}, 4.0$ equiv.) and copper(I) thiophene-2-carboxylate (26.8 $\mathrm{mg}, 0.141 \mathrm{mmol}, 2.0$ equiv. $)^{10}$ were sequentially added to a stirred solution of the vinyliodide $\mathbf{1 5}$ (40 mg, $0.07 \mathrm{mmol}, 1.0$ equiv.) in degassed $N, N$-dimethylacetamide $(0.5 \mathrm{~mL})$ at room temperature under an atmosphere of argon. The resulting mixture was then stirred for $c a .16$ hours at $80{ }^{\circ} \mathrm{C}$, before being cooled to room temperature and quenched by the addition of $\mathrm{pH} 7$ buffer solution (5 $\mathrm{mL}$ ). The reaction mixture was then partitioned between diethyl ether and water and the organic phases were combined, washed successively with ice-cold water and saturated $\mathrm{NaCl}$ solution, dried (anhyd. $\mathrm{Na}_{2} \mathrm{SO}_{4}$ ), filtered and concentrated in vacuo to afford the crude product. Purification by flash chromatography ( $\mathrm{SiO}_{2}$, gradient elution with 40:60 to 90:10 ethyl acetate/pentane) afforded the vinyl formamide SI-5 (30 mg, 83\%) as a colorless oil.

$[\alpha]_{\mathrm{D}}^{20}-36.4\left(\mathrm{c}=0.17, \mathrm{CHCl}_{3}\right)$

${ }^{1} \mathbf{H}$ NMR $\left(500 \mathrm{MHz}, \mathrm{CDCl}_{3}\right) \delta 8.19(\mathrm{~s}, 1 \mathrm{H}) *[8.07(\mathrm{~s}, 1 \mathrm{H})], 6.25(\mathrm{~d}, J=14.3 \mathrm{~Hz}, 1 \mathrm{H}) *[6.90(\mathrm{~d}, J=$ $15.0 \mathrm{~Hz}, 1 \mathrm{H})], 5.21-5.18(\mathrm{~m}, 1 \mathrm{H}), 5.10(\mathrm{dd}, J=14.8,9.1 \mathrm{~Hz}, 1 \mathrm{H}) *[5.19-5.14(\mathrm{~m}, 1 \mathrm{H})], 4.43-4.40(\mathrm{~m}$, 1H), 3.99 (app. q, $J=7.0 \mathrm{~Hz}, 1 \mathrm{H}), 3.90$ (app. q, $J=6.7 \mathrm{~Hz}, 1 \mathrm{H}), 3.61-3.47$ (m, 3H), 3.40 (s, 3H), 3.32 (s, 3H), 3.26-3.25 (m, 1H), $2.78(\mathrm{dd}, J=9.3,2.1 \mathrm{~Hz}, 1 \mathrm{H}), 2.45-2.33(\mathrm{~m}, 2 \mathrm{H}), 2.26-2.19$ (m, 1H), 2.02$1.87(\mathrm{~m}, 3 \mathrm{H}), 1.79-1.71(\mathrm{~m}, 1 \mathrm{H}), 1.63-1.50(\mathrm{~m}, 4 \mathrm{H}), 1.47-1.38(\mathrm{~m}, 3 \mathrm{H}), 1.12$ (d, J = 6.8 Hz, 3H), 1.09 $(\mathrm{t}, J=7.1 \mathrm{~Hz}, 3 \mathrm{H}) *[1.20(\mathrm{t}, J=7.0 \mathrm{~Hz}, 3 \mathrm{H})], 0.98-0.94(\mathrm{~m}, 1 \mathrm{H}), 0.90(\mathrm{~d}, J=6.5 \mathrm{~Hz}, 3 \mathrm{H}) *[0.90(\mathrm{~d}, J$ 
$=6.9 \mathrm{~Hz}, 3 \mathrm{H})], 0.85(\mathrm{~d}, J=6.7 \mathrm{~Hz}, 3 \mathrm{H}) *[0.81(\mathrm{~d}, J=6.2 \mathrm{~Hz}, 3 \mathrm{H})], 0.85(\mathrm{~d}, J=6.7 \mathrm{~Hz}, 3 \mathrm{H}), 0.83(\mathrm{~d}$, $J=6.7 \mathrm{~Hz}, 3 \mathrm{H})$.

${ }^{13}$ C NMR (125 MHz, $\left.\mathrm{CDCl}_{3}\right) \delta 173.16$ (e) *(173.19), 161.88 (o) *(160.80), 127.03 (o) *(122.70), 112.18 (о) *(113.63), 86.58 (о) *(86.62), 82.93 (o), 77.19 (o), 74.17 (o) *(74.26), 73.82 (o) *(73.91), 69.31 (e), 61.76 (o) *(61.87), 57.82 (o) *(57.74), 39.43 (о) *(39.48), 38.06 (o) *(38.41), 35.75 (e) *(40.82), 34.99 (o) *(34.93), 34.02 (o) *(33.99), 33.61 (e) *(33.52), 30.40 (e)*(30.44), 30.36 (e) *(30.21), 27.48 (e) *(27.34), 25.32 (e), 19.94 (o) *(20.06), 18.84 (o) *(18.86), 17.82 (o) *(17.91), 15.65 (o) *(14.01), 11.95 (o), 9.89 (o) *(9.71).

IR (neat) 3462 (br, w), 2956 (m), 2929 (m), 2873 (m), 1729 (m), 1687 (m), 1651 (s), 1459 (m), 1404 (m), 1379 (m), 1363 (m), 1312 (w), 1274 (m), 1255 (m), 1218 (m), 1201 (m), 1089 (s), 1037 (m), 968 (m), $940(\mathrm{~m}), 912(\mathrm{w}), 867(\mathrm{w}), 817(\mathrm{w}), 798(\mathrm{w}), 714(\mathrm{w}), 677(\mathrm{w}) \mathrm{cm}^{-1}$.

HRMS (ESI, $[\mathrm{M}+\mathrm{H}]^{+}$) calcd for $\mathrm{C}_{28} \mathrm{H}_{52} \mathrm{NO}_{7} 514.3738$, found 514.3727.

$(3 R, 4 R, 5 S, 6 R, 9 S, 10 S, 12 S, E)-12-[(4-A z i d o b u t a n o y l) o x y]-1-(N$-ethylformamido)-4,10-dimethoxy3,5,9,13-tetramethyltetradec-1-en-6-yl $(R)$-tetrahydrofuran-2-carboxylate (SI-6)
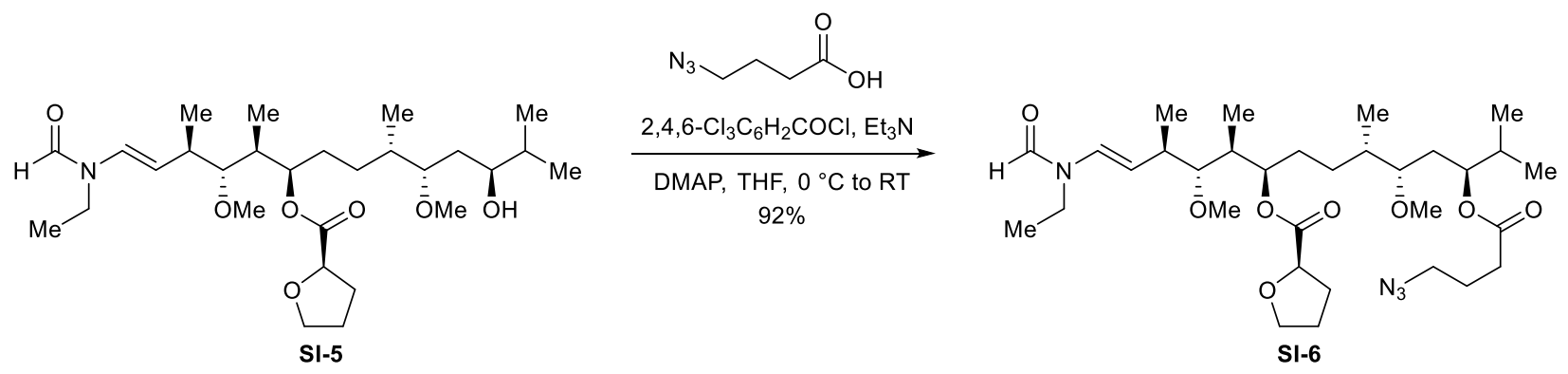

Anhydrous triethylamine $(0.021 \mathrm{~mL}, 0.152 \mathrm{mmol}, 3.0$ equiv. $)$ and 2,4,6-trichlorobenzoyl chloride $(0.024 \mathrm{~mL}, 0.152 \mathrm{mmol}, 3.0$ equiv.) were added to a stirred solution of the 4-azidobutanoic acid (20 $\mathrm{mg}, 0.152 \mathrm{mmol}, 3.0$ equiv. $)$ in THF $(1.5 \mathrm{~mL})$ at room temperature under an atmosphere of argon. The resulting mixture was stirred for $c a .2$ hours, and then the precipitated salts were removed using a syringe tip filter. The mixed anhydride solution was then added to a stirred solution of the secondary alcohol SI-5 (26 mg, $0.051 \mathrm{mmol}$ ) and 4-dimethylaminopyridine (12 mg, $0.101 \mathrm{mmol}, 2.0$ equiv.) in THF $(1.5 \mathrm{~mL})$ at $0{ }^{\circ} \mathrm{C}$ under an atmosphere of argon. The mixture was then warmed to room temperature and stirred for $c a$. 16 hours (TLC control). The reaction was then quenched by the addition of saturated aqueous $\mathrm{NaHCO}_{3}$ solution and partitioned between diethyl ether and water. The organic phases were combined, dried (anhyd. $\mathrm{Na}_{2} \mathrm{SO}_{4}$ ), filtered and was concentrated in vacuo to 
afford the crude product. Purification by flash chromatography $\left(\mathrm{SiO}_{2}\right.$, gradient elution with 40:60 to 90:10 ethyl acetate/pentane) afforded the ester SI-6 (29 mg, 92\%) as a colorless oil.

$[\alpha]_{\mathrm{D}}^{20}-36.7\left(\mathrm{c}=0.4, \mathrm{CHCl}_{3}\right)$

${ }^{1} \mathbf{H}$ NMR $\left(500 \mathrm{MHz}, \mathrm{CDCl}_{3}\right) \delta 8.22(\mathrm{~s}, 1 \mathrm{H}) *[8.10(\mathrm{~s}, 1 \mathrm{H})], 6.27(\mathrm{~d}, J=14.3 \mathrm{~Hz}, 1 \mathrm{H}) *[6.93(\mathrm{~d}, J=$ $15.0 \mathrm{~Hz}, 1 \mathrm{H}), 5.23-5.21(\mathrm{~m}, 1 \mathrm{H}), 5.13(\mathrm{dd}, J=14.4,9.2 \mathrm{~Hz}, 1 \mathrm{H}) *[5.16(\mathrm{dd}, J=15.2,9.5 \mathrm{~Hz}, 1 \mathrm{H})]$, 4.98 (ddd, $J=7.5,4.7,3.1 \mathrm{~Hz}, 1 \mathrm{H}), 4.47-4.43$ (m, 1H), 4.01 (app. q, $J=7.1 \mathrm{~Hz}, 1 \mathrm{H}), 3.93$ (app. q, $J=$ $6.9 \mathrm{~Hz}, 1 \mathrm{H}), 3.62(\mathrm{dq}, J=13.4,6.8 \mathrm{~Hz}, 1 \mathrm{H}), 3.58(\mathrm{dq}, J=13.5,6.7 \mathrm{~Hz}, 1 \mathrm{H}) *[3.51(\mathrm{q}, J=6.8 \mathrm{~Hz}$, 2H)], $3.43(\mathrm{~s}, 3 \mathrm{H}), 3.37(\mathrm{t}, J=6.6 \mathrm{~Hz}, 2 \mathrm{H}), 3.28(\mathrm{~s}, 3 \mathrm{H}), 2.88(\mathrm{dt}, J=7.8,3.8 \mathrm{~Hz}, 1 \mathrm{H}), 2.80(\mathrm{dd}, J=$ 9.3, $2.3 \mathrm{~Hz}, 1 \mathrm{H}), 2.41(\mathrm{t}, J=6.9 \mathrm{~Hz}, 2 \mathrm{H}) *[2.46(\mathrm{t}, J=7.3 \mathrm{~Hz}, 2 \mathrm{H})], 2.47-2.40(\mathrm{~m}, 1 \mathrm{H}), 2.28-2.21(\mathrm{~m}$, 1H), 2.05-1.89 (m, 5H), 1.79 (app. sextet, $J=6.3 \mathrm{~Hz}, 1 \mathrm{H}), 1.74-1.67(\mathrm{~m}, 1 \mathrm{H}), 1.63-1.52(\mathrm{~m}, 3 \mathrm{H})$, 1.50-1.42 (m, 3H), $1.15(\mathrm{~d}, J=6.8 \mathrm{~Hz}, 3 \mathrm{H}), 1.11(\mathrm{t}, J=7.1 \mathrm{~Hz}, 3 \mathrm{H}) *[1.22(\mathrm{t}, J=7.0 \mathrm{~Hz}, 3 \mathrm{H})], 1.00-$ $0.92(\mathrm{~m}, 1 \mathrm{H}), 0.87(\mathrm{~d}, J=6.7 \mathrm{~Hz}, 3 \mathrm{H}) *[0.83(\mathrm{~d}, J=6.9 \mathrm{~Hz}, 3 \mathrm{H})], 0.87(\mathrm{~d}, J=6.7 \mathrm{~Hz}, 3 \mathrm{H}), 0.85(\mathrm{~d}, J$ $=7.2 \mathrm{~Hz}, 3 \mathrm{H}), 0.83(\mathrm{~d}, J=7.1 \mathrm{~Hz}, 3 \mathrm{H})$.

${ }^{13}$ C NMR (125 MHz, $\left.\mathrm{CDCl}_{3}\right) \delta 173.24$ (e) *(173.27), 172.54 (e), 162.02 (o) *(160.92), 127.08 (o) *(122.75), 112.27 (o) *(113.78), 86.62 (o)*(86.67), 81.94 (o) *(81.90), 77.26 (o), 76.03 (o), 74.22 (o) *(74.31), 69.37 (e), 61.83 (o)*(61.94), 58.07 (o), 50.82 (e)*(50.65), 39.51 (o)*(39.57), 38.12 (o) *(38.47), 35.82 (e)*(40.90), 35.07 (o)*(35.03), 32.35 (e)*(32.32), 32.27 (o), 31.50 (e), 30.69 (e) *(30.54), 30.47 (e)*(30.51), 27.28 (e)*(27.19), 25.37 (e), 24.55 (e), 19.99 (o)*(20.13), 18.53 (o), 17.57 (o) *(17.61), 15.53 (o)*(15.50), 12.01 (o)*(14.06), 9.92 (o)*(9.75).

IR (neat) 2966 (m), 2935 (m), $2877(\mathrm{~m}), 2833(\mathrm{w}), 2098(\mathrm{~m}), 1728(\mathrm{~s}), 1692(\mathrm{~m}), 1654$ (s), 1460 (m), 1406 (m), 1368 (m), 1344 (m), 1274 (m), 1255 (m), 1202 (m), 1171 (m), 1090 (vs), 1033 (m), 969 (m), 941 (m), 913 (m), $870(w), 817(w), 799(w), 714(w), 675(w) \mathrm{cm}^{-1}$.

HRMS (ESI, $[\mathrm{M}+\mathrm{Na}]^{+}$) calcd for $\mathrm{C}_{32} \mathrm{H}_{56} \mathrm{~N}_{4} \mathrm{NaO}_{8} 647.3990$, found 647.3979.

$(3 R, 4 R, 5 S, 6 R, 9 S, 10 S, 12 S, E)-12-[(4-A m i n o b u t a n o y l) o x y]-1-(N$-ethylformamido)-4,10-dimethoxy3,5,9,13-tetramethyltetradec-1-en-6-yl $(R)$-tetrahydrofuran-2-carboxylate (2)
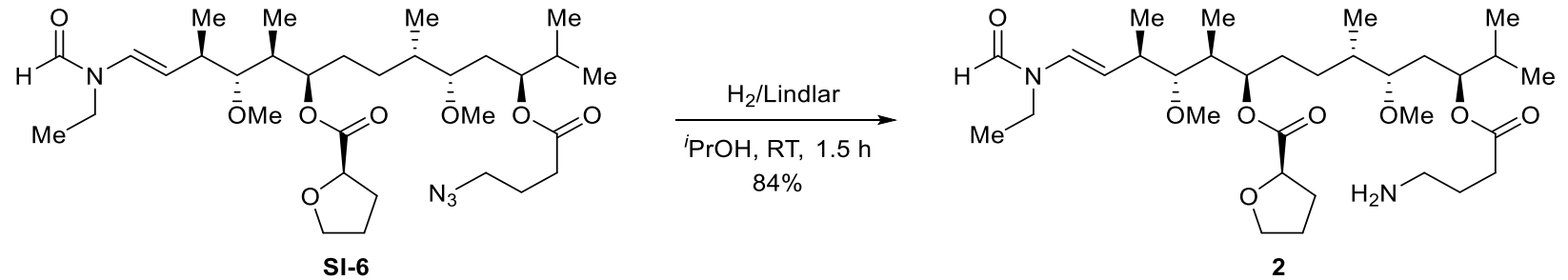
Lindlar catalyst (143 mg, 5\% by wt.) was added to a stirred solution of azide SI-6 (21 mg, 0.034 $\mathrm{mmol})$ in isopropanol $(2 \mathrm{~mL})$ at room temperature. The reaction flask was evacuated, backfilled with hydrogen and stirred for $c a .1 .5$ hours under an atmosphere of hydrogen (TLC control). The mixture was then filtered through a pad of Celite ${ }^{\circledR}$ to remove the catalyst and the filter cake was washed with isopropanol $(3 \mathrm{~mL})$. The filtrate was concentrated in vacuo to afford the crude product. Purification by flash chromatography $\left(\mathrm{SiO}_{2}\right.$, gradient elution with 5:95 to 10:90 methanol/dichloromethane) afforded the amine $2(17 \mathrm{mg}, 84 \%)$ as a colorless oil.

$[\alpha]_{\mathrm{D}}^{20}-17.5\left(\mathrm{c}=0.25, \mathrm{CHCl}_{3}\right)$

${ }^{1} \mathbf{H}$ NMR $\left(500 \mathrm{MHz}, \mathrm{CDCl}_{3}\right) \delta 8.23(\mathrm{~s}, 1 \mathrm{H}) *[8.11(\mathrm{~s}, 1 \mathrm{H})], 6.28(\mathrm{~d}, J=14.3 \mathrm{~Hz}, 1 \mathrm{H}) *[6.93(\mathrm{~d}, J=$ $14.8 \mathrm{~Hz}, 1 \mathrm{H})], 5.58$ (br. s, 2H), 5.22-5.18 (m, 1H), 5.12 (dd, $J=14.4,9.3 \mathrm{~Hz}, 1 \mathrm{H}) *[5.15(\mathrm{dd}, J=$ $15.4,9.6 \mathrm{~Hz}, 1 \mathrm{H})], 4.97-4.93(\mathrm{~m}, 1 \mathrm{H}), 4.46-4.43(\mathrm{~m}, 1 \mathrm{H}), 4.04$ (app. q, $J=7.0 \mathrm{~Hz}, 1 \mathrm{H}), 3.93$ (app. q, $J$ $=7.0 \mathrm{~Hz}, 1 \mathrm{H}), 3.63(\mathrm{dq}, J=13.7,6.9 \mathrm{~Hz}, 1 \mathrm{H}), 3.57(\mathrm{dq}, J=13.8,6.9 \mathrm{~Hz}, 1 \mathrm{H}) *[3.52(\mathrm{q}, J=7.0 \mathrm{~Hz}$, 2H)], 3.41 (s, 3H), 3.30 (s, 3H), 3.03 (br. s, 2H), 2.91-2.87 (m, 1H), 2.80-2.77 (m, 1H), 2.46 (t, $J=7.3$ $\mathrm{Hz}, 2 \mathrm{H}), 2.45-2.39(\mathrm{~m}, 1 \mathrm{H}), 2.30-2.23(\mathrm{~m}, 1 \mathrm{H}), 2.05-1.90(\mathrm{~m}, 5 \mathrm{H}), 1.83-1.77(\mathrm{~m}, 1 \mathrm{H}), 1.65-1.53(\mathrm{~m}$, $4 \mathrm{H}), 1.49-1.47(\mathrm{~m}, 2 \mathrm{H}), 1.45-1.36(\mathrm{~m}, 1 \mathrm{H}), 1.15(\mathrm{~d}, J=6.7 \mathrm{~Hz}, 3 \mathrm{H}), 1.12(\mathrm{t}, J=7.1 \mathrm{~Hz}, 3 \mathrm{H}) *[1.23(\mathrm{t}$, $J=7.0 \mathrm{~Hz}, 3 \mathrm{H})], 0.99-0.92(\mathrm{~m}, 1 \mathrm{H}), 0.87-0.83(\mathrm{~m}, 12 \mathrm{H})$.

${ }^{13}$ C NMR (125 MHz, $\left.\mathrm{CDCl}_{3}\right) \delta 173.54$ (e) *(173.59), 172.79 (e) *(172.83), 162.09 (o) *(160.96), 127.08 (o) *(122.76), 112.34 (o) *(113.78), 86.67 (o) *(86.72), 81.77 (o) *(81.65), 77.21 (o), 76.46 (o) *(76.43), 74.54 (o) *(74.66), 69.45 (e), 61.87 (o) *(61.96), 58.44 (o) *(58.48), 39.34 (o) *(39.49), 38.15 (o) *(38.48), 35.83 (e) *(40.92), 35.74 (o), 32.80 (e), 32.20 (o) *(32.23), 31.93 (e), 30.54 (e), 30.52 (e) *(30.43), 30.50 (e), 27.76 (e), 25.39 (e), 19.98 (o) *(20.13), 18.50 (o) *(18.48), 17.65 (o) *(17.71), 15.41 (o) *(15.40), 12.03 (o) *(14.07), 9.97 (o) *(9.83).

IR (neat) 3400-2600 (br, m), 2967 (m), 2935 (m), 2878 (m), 2834 (w), 1729 (m), 1691 (m), 1653 (s), 1520 (w), 1461 (m), 1405 (m), 1379 (m), 1343 (m), 1311 (m), 1281 (m), 1256 (m), 1197 (s), 1144 (m), 1089 (s), 1034 (m), 1007 (m), 970 (m), 942 (m), 915 (m), 819 (w), 798 (w), 730 (m), 675 (w) $\mathrm{cm}^{-1}$.

HRMS (ESI, $[\mathrm{M}+\mathrm{H}]^{+}$) calcd for $\mathrm{C}_{32} \mathrm{H}_{59} \mathrm{~N}_{2} \mathrm{O}_{8} 599.4266$, found 599.4263 . 


\section{Table S1. X-Ray Data Collection and Refinement Statistics}

\begin{tabular}{|c|c|c|}
\hline & Actin-MycB & Actin-2-LatB \\
\hline \multicolumn{3}{|l|}{ Data collection $^{\mathrm{a}}$} \\
\hline Wavelength $(\AA)$ & 0.98 & 0.98 \\
\hline Resolution range $(\AA)^{b}$ & $40.2-1.67(1.73-1.67)$ & $37.43-1.7(1.761-1.7)$ \\
\hline Space group & P 1211 & P 1211 \\
\hline \multicolumn{3}{|l|}{ Cell dimensions } \\
\hline $\mathrm{a}, \mathrm{b}, \mathrm{c}(\AA)$ & $40.77,75.61,67.55$ & $37.76,74.87,61.19$ \\
\hline$\alpha, \beta, \gamma\left({ }^{\circ}\right)$ & $90,99.61,90$ & $90,93.02,90$ \\
\hline Total reflections & $147607(14622)$ & $73536(7207)$ \\
\hline Unique reflections & $46543(4622)$ & 36904 (3609) \\
\hline Multiplicity & $3.2(3.1)$ & $2.0(2.0)$ \\
\hline Completeness (\%) & $98.98(98.38)$ & $98.49(97.38)$ \\
\hline Mean I/sigma(I) & $6.77(0.30)$ & $10.05(0.72)$ \\
\hline Wilson B-factor & 24.33 & 23.76 \\
\hline R-merge & $0.1466(3.674)$ & $0.04321(1.072)$ \\
\hline $\mathrm{R}$-meas & $0.1771(4.463)$ & $0.06111(1.516)$ \\
\hline R-pim & $0.09788(2.495)$ & $0.04321(1.072)$ \\
\hline $\mathrm{CC} 1 / 2$ & $0.994(0.05)$ & $0.997(0.223)$ \\
\hline $\mathrm{CC}^{*}$ & $0.999(0.309)$ & $0.999(0.604)$ \\
\hline \multicolumn{3}{|l|}{ Refinement $^{b}$} \\
\hline Reflections used in refinement & $46475(4622)$ & $36888(3601)$ \\
\hline Reflections used for R-free & $2325(232)$ & $1828(172)$ \\
\hline R-work & $0.1945(0.4022)$ & $0.1790(0.5964)$ \\
\hline $\mathrm{R}$-free & $0.2431(0.4220)$ & $0.2135(0.5886)$ \\
\hline CC(work) & $0.967(0.216)$ & $0.967(0.521)$ \\
\hline $\mathrm{CC}$ (free) & $0.932(0.189)$ & $0.937(0.340)$ \\
\hline Number of non-hydrogen atoms & 3016 & 3225 \\
\hline macromolecules & 2799 & 2801 \\
\hline ligands & 102 & 113 \\
\hline solvent & 115 & 311 \\
\hline Protein residues & 359 & 365 \\
\hline RMS(bond lengths) $(\AA)$ & 0.011 & 0.014 \\
\hline RMS(angles) $\left(^{\circ}\right)$ & 1.57 & 1.38 \\
\hline Ramachandran favoured (\%) & 98.03 & 98.02 \\
\hline Ramachandran allowed (\%) & 1.97 & 1.98 \\
\hline Ramachandran outliers (\%) & 0.00 & 0.00 \\
\hline Rotamer outliers (\%) & 0.33 & 0.00 \\
\hline Clash score & 2.29 & 3.84 \\
\hline Average B-factor & 29.60 & 25.07 \\
\hline macromolecules & 29.66 & 24.09 \\
\hline ligands & 27.66 & 22.28 \\
\hline solvent & 29.66 & 34.16 \\
\hline
\end{tabular}

${ }^{a}$ Data were collected on a single crystal; ${ }^{b}$ Values in parentheses are for the highest-resolution shell. 


\section{Figure S1. Effects of MycB and Analogue 2 on Actin Polymerization}

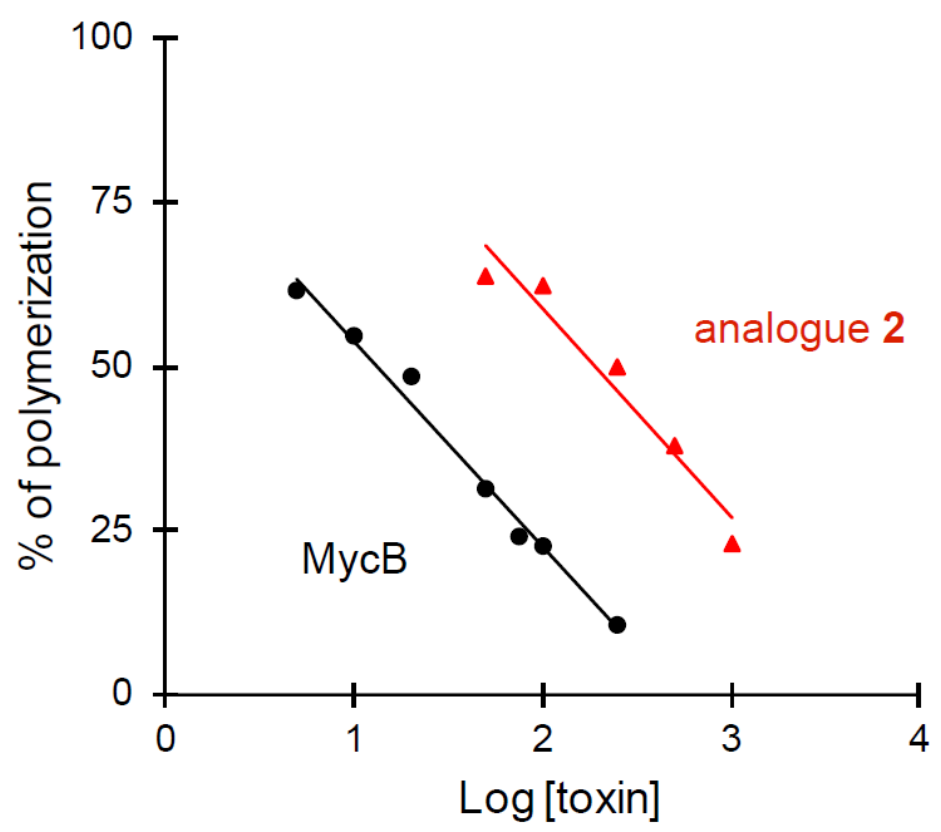

Polymerization rates were determined by measuring the slope of plots in Figure 3 (A-B). Polymerization rate of actin in the absence of toxin was normalized to $100 \%$. The rate of polymerization in the presence of toxin was expressed as a percentage relative to the no toxin value and plotted as a function of $\log$ toxin concentration (in $\mathrm{nM}$ ). $\mathrm{IC}_{50}$ values for each compound were extrapolated from the plots as the concentration of toxin at which $50 \%$ of the maximal rate of polymerization was observed. 


\section{Figure S2. ECM Degradation Assay}

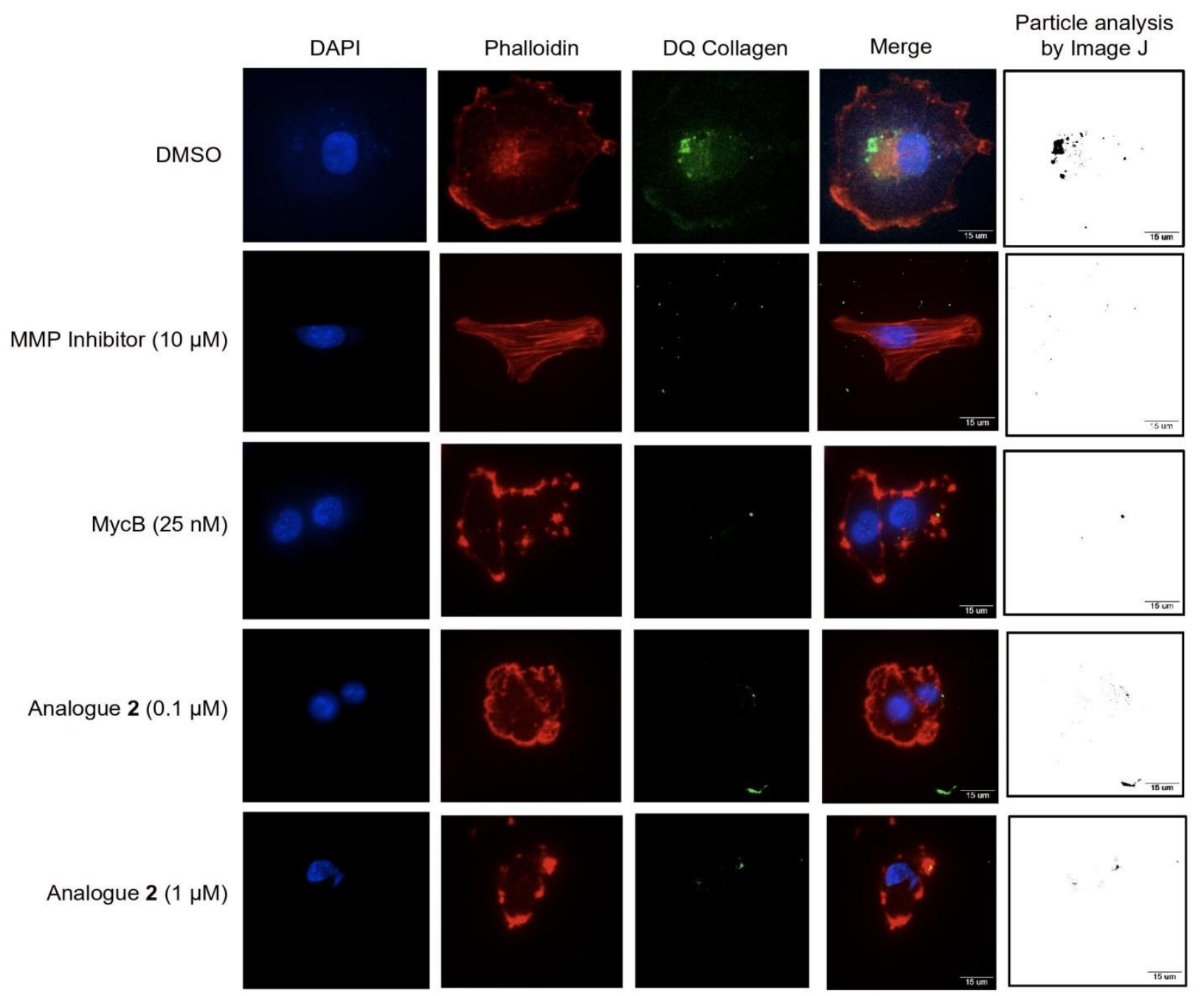

Analogue 2 inhibits ECM degradation by invadopodia in SKOV3 cells. ECM degradation assay was performed on SKOV3 cells that were seeded on coverslips coated with a mixture of DQ collagen and Matrigel for 8 hours prior to treatment with DMSO control, Myc B $(25 \mathrm{nM})$, analogue $2(0.1 \mu \mathrm{M}$ and $1 \mu \mathrm{M}$ ), or MMP inhibitor- Ilomastat (positive control, $10 \mu \mathrm{M}$ ) for 4 hours. The amount of green fluorescence per field in confocal micrographs was analyzed and quantified using Image $J$ software. Representative images and analysis of one cell for each condition are shown. 


\section{Figure S3. LIGPLOT of the Actin-MycB (A) and Actin-2 (B) Contacts}

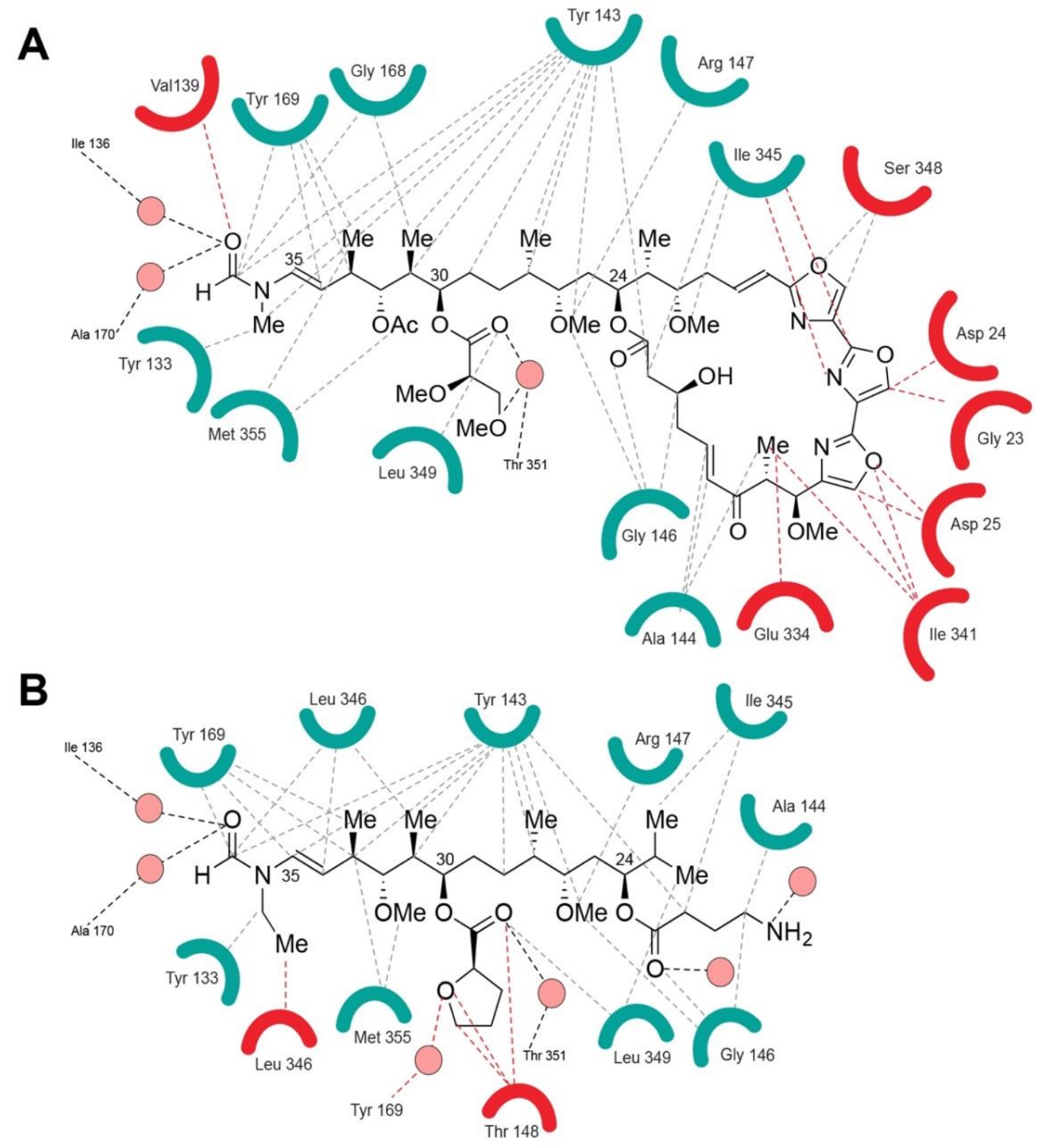

Schematic representation of the interactions made by $\mathrm{MycB}$ and analogue 2 with actin. Van der Waals and hydrophobic contacts are represented by thin dashed grey lines. Water molecules are depicted as pink spheres with their hydrogen bonding interactions connected by thick dashed black lines. Amino acids that interact with both $\mathrm{MycB}$ and analogue 2 are denoted with green crescents. Amino acids that interact with only $\mathrm{MycB}$ or analogue $\mathbf{2}$ are denoted with red crescents. 
7. Table S2. Structure-Activity Relationship Studies of Truncated Mycalolide B Analogues

\begin{tabular}{|c|c|c|c|c|c|}
\hline $\mathbf{N}^{\circ}$ & Structure of Truncated Analogue & Variation & $\begin{array}{l}\mathrm{IC}_{50} \\
(\mu \mathrm{M})\end{array}$ & $\begin{array}{c}\text { Cell } \\
\text { Invasion }\end{array}$ & Remarks \\
\hline S1 & & $\mathrm{C} 30$ & 1.5 & NS & \multirow{2}{*}{$\begin{array}{l}\text { Stereochemistry of } \\
\text { C30 is critical for } \\
\text { actin polymerization } \\
\text { inhibition }\end{array}$} \\
\hline S2 & & C30 & 6.0 & - & \\
\hline S3 & & $\mathrm{C} 30$ & 1.0 & NS & \multirow{2}{*}{$\begin{array}{l}\text { Isopropyl substituent } \\
\text { is preferred at C24 } \\
\text { (branching) }\end{array}$} \\
\hline S4 & & C24 & 0.3 & NS & \\
\hline S5 & & $\mathrm{C} 30$ & 2.1 & NS & \multirow{2}{*}{$\begin{array}{l}\text { The tetrahydrofuranyl } \\
\text { ester with }(R)- \\
\text { configuration } \\
\text { superior for actin } \\
\text { polymerization } \\
\text { inhibition }\end{array}$} \\
\hline S6 & & C30 & 0.1 & NS & \\
\hline S7 & & $\mathrm{C} 35-\mathrm{N}$ & 0.1 & NS & \multirow{2}{*}{$\begin{array}{l}\text { The } N \text {-Ethyl } \\
\text { substituent at } \text { the } \\
\text { vinylformamide is } \\
\text { optimal for actin } \\
\text { polymerization } \\
\text { inhibition }\end{array}$} \\
\hline S8 & & $\mathrm{C} 35-\mathrm{N}$ & 0.3 & NS & \\
\hline S9 & & $\mathrm{C} 24$ & 0.1 & NS & \\
\hline
\end{tabular}




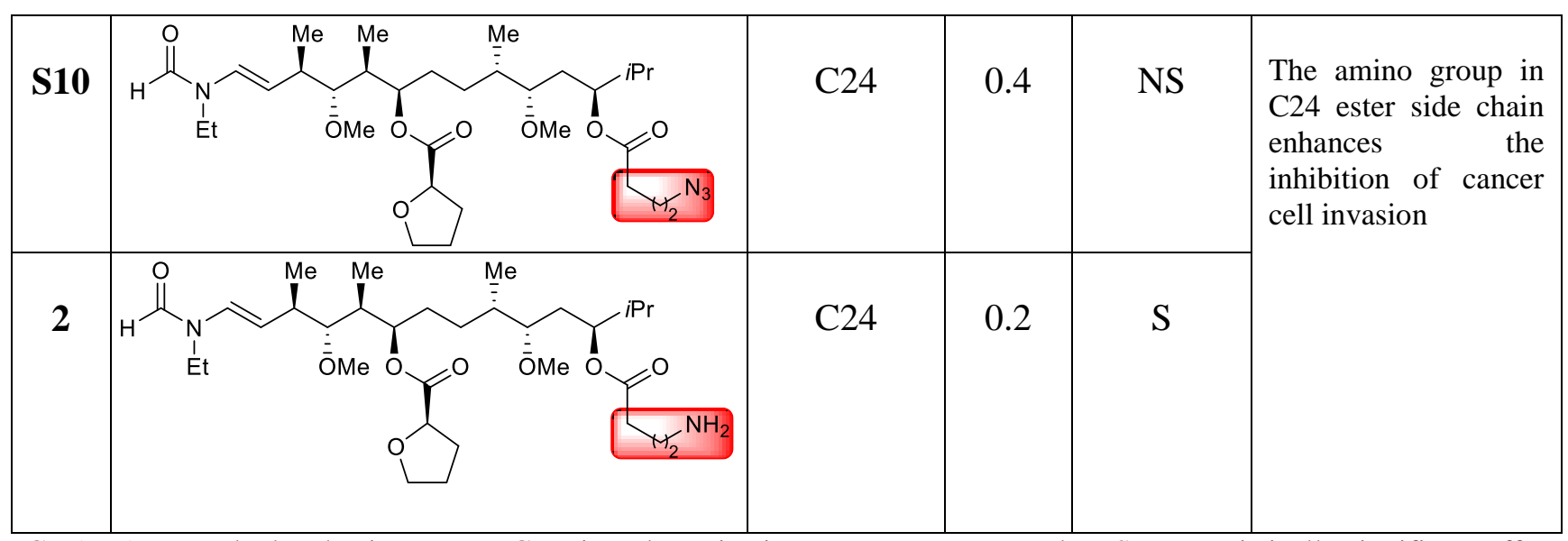

$\mathrm{IC}_{50}(\mu \mathrm{M})$ was calculated using pyrene G-actin polymerization assay. -: Not tested. NS: No statistically significant effect was observed at $5 \mu \mathrm{M}$ of analogue. S: Statistically significant effect was observed at $5 \mu \mathrm{M}$ of analogue.

\section{References}

1. Paterson, I.; Steadman, V. A.; McLeod, M. D.; Trieselmann, T. Stereocontrolled total synthesis of (+)concanamycin F: The strategic use of boron-mediated aldol reactions of chiral ketones. Tetrahedron 2011, 67, 10119-10128.

2. Paquette, L. A.; Guevel, R.; Sakamoto, S.; Kim, I. H.; Crawford, J. Convergent enantioselective synthesis of vinigrol, an architecturally novel diterpenoid with potent platelet aggregation inhibitory and antihypertensive properties. 1. Application of anionic sigmatropy to construction of the octalin substructure. J. Org. Chem. 2003, 68, 6096-6107.

3. Lister, T, Perkins, M. V. A retro-Claisen approach to dolabriferol. Org. Lett. 2006, 8, 1827-1830.

4. Evans, D. A.; Ratz, A. M.; Huff, B. E.; Sheppard, G. S. Total synthesis of the polyether antibiotic lonomycin A (emericid). J. Am. Chem. Soc. 1995, 117, 3448-3467.

5. The absolute configuration of the newly formed stereocenter was confirmed via Mosher's ester analysis.

6. Cossrow, J.; Rychnovsky, S. D. Optically pure $\alpha$-(trimethylsilyl)benzyl alcohol: A practical chiral auxiliary for oxocarbenium ion reactions. Org. Lett. 2002, 4, 147-150.

7. Suen, L. M.; Steigerwald, M. L.; Leighton, J. L. A new and more powerfully activating siamine for practical and scalable enantioselective aldehyde crotylsilylation reactions. Chem. Sci. 2013, 4, 2413-2417.

8. Cusack, N.; Reese, C. B.; Risius, A. C.; Roozpeikar, B. 2,4,6-Tri-isopropylbenzenesulphonyl hydrazide: A convenient source of diimide. Tetrahedron 1976, 32, 2157-2162.

9. Takai, K.; Nitta, K.; Utimoto, K. Simple and selective method for $\mathrm{RCHO} \rightarrow(E)-\mathrm{RCH}=\mathrm{CHX}$ conversion by means of a $\mathrm{CHX}_{3}-\mathrm{CrCI}_{2}$ System. J. Am. Chem. Soc. 1986, 108, 7408-7410.

10. Shen, R.; Lin, C. T.; Bowman, E. J.; Bowman, B. J; Porco, J. A. Lobatamide C: Total synthesis, stereochemical assignment, preparation of simplified analogues, and V-ATPase inhibition studies. J. Am. Chem. Soc. 2003, 125, 7889-7890. 


\section{Copies of NMR Spectra}
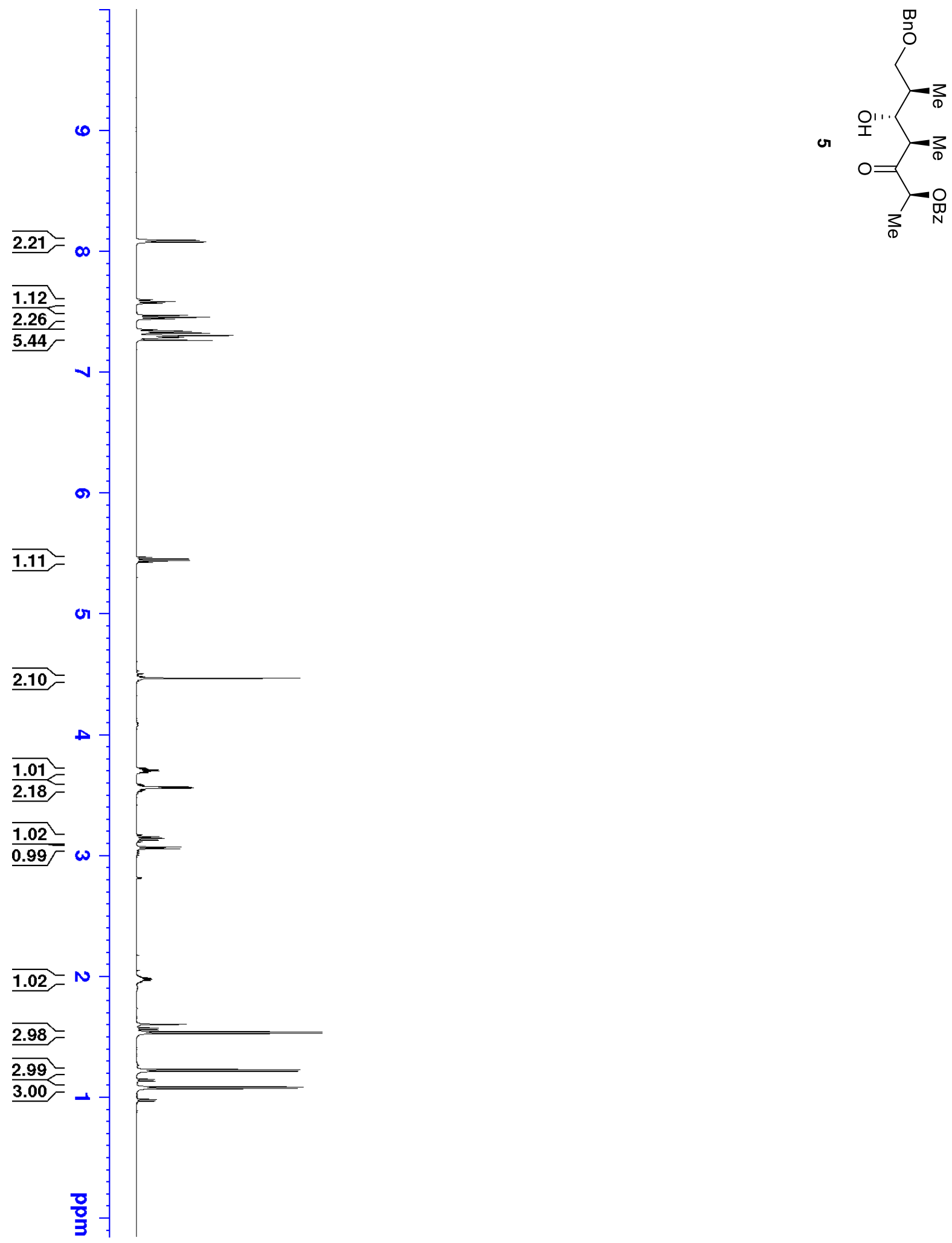

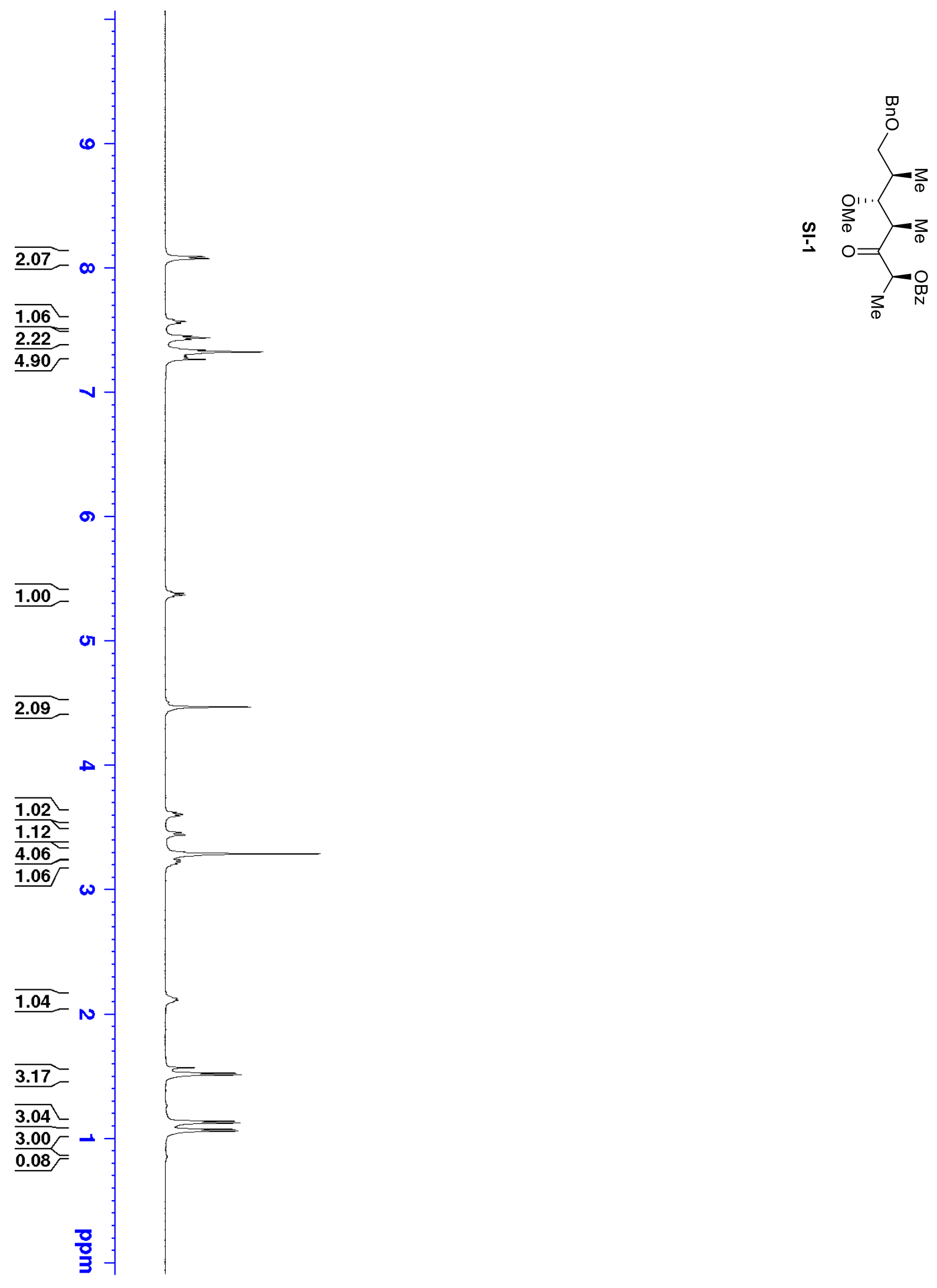


$$
f
$$



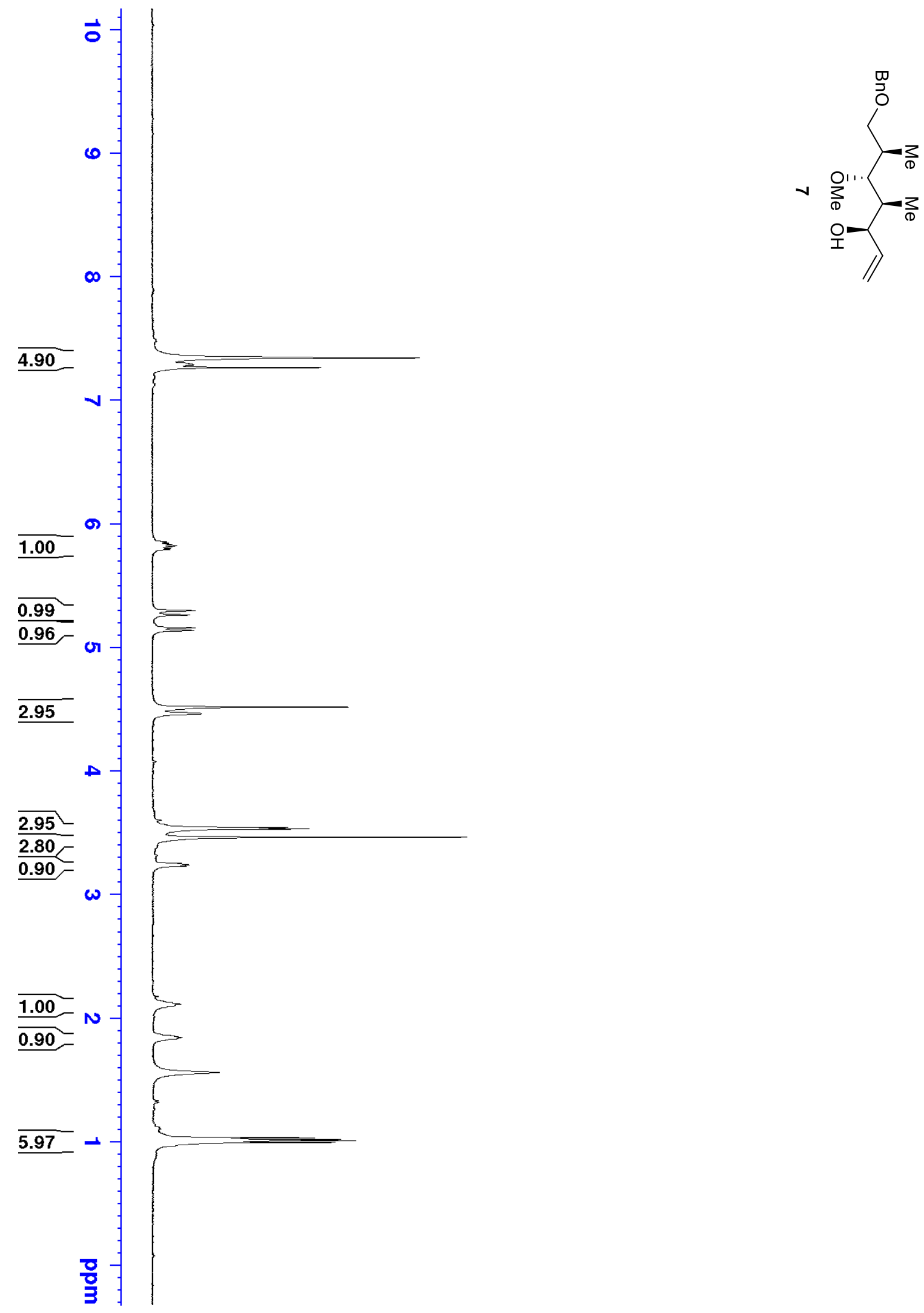


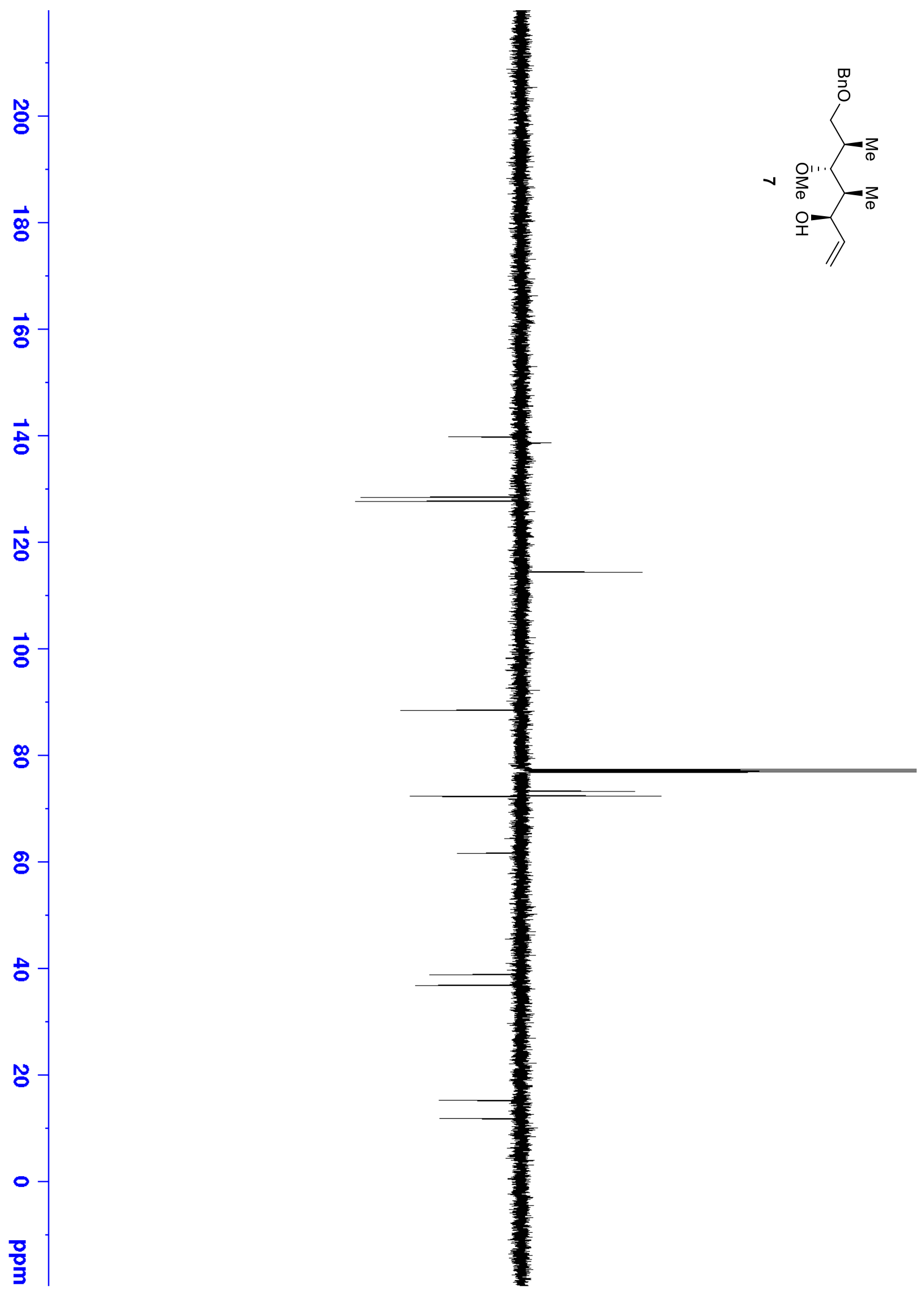



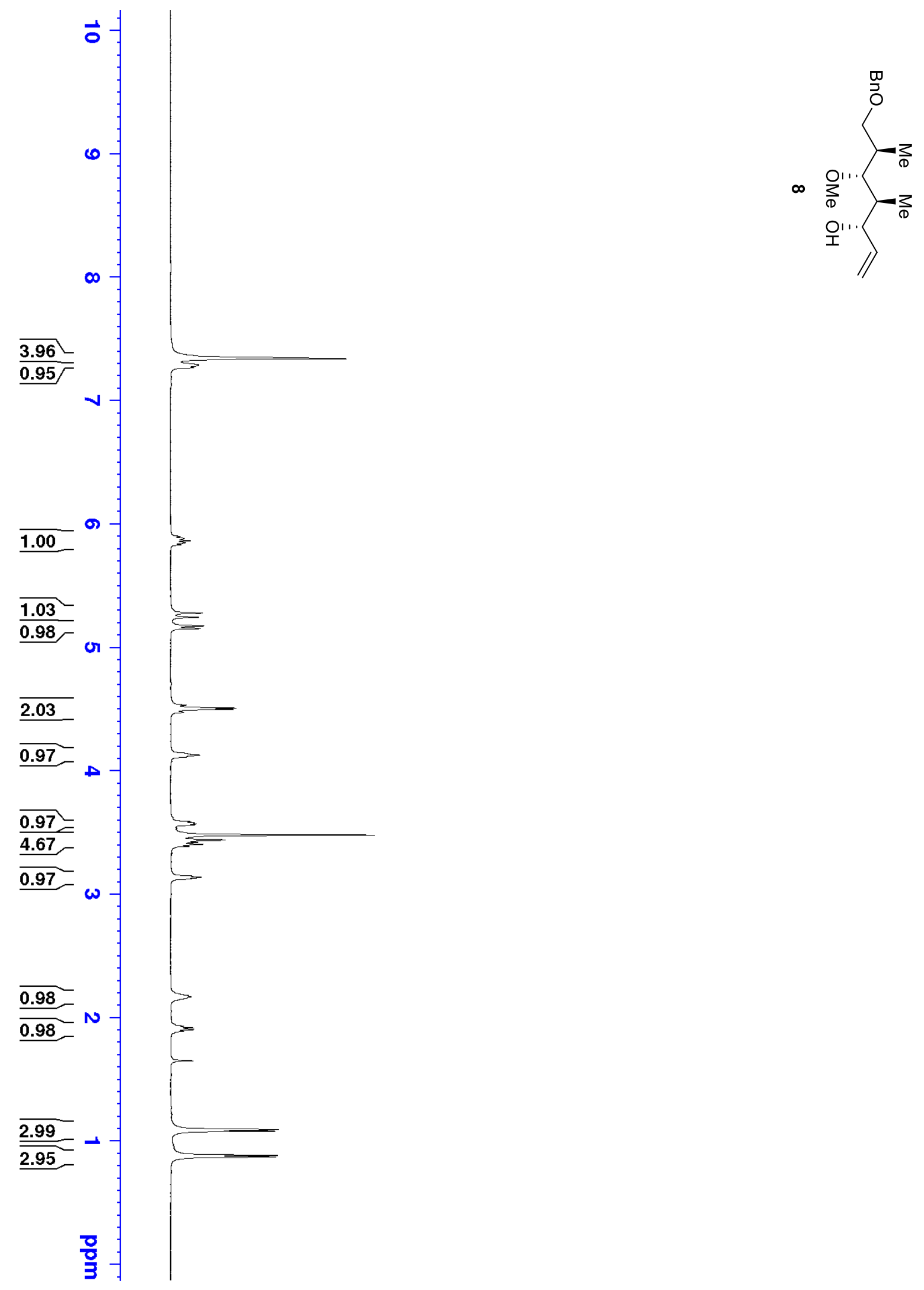


$$
1
$$



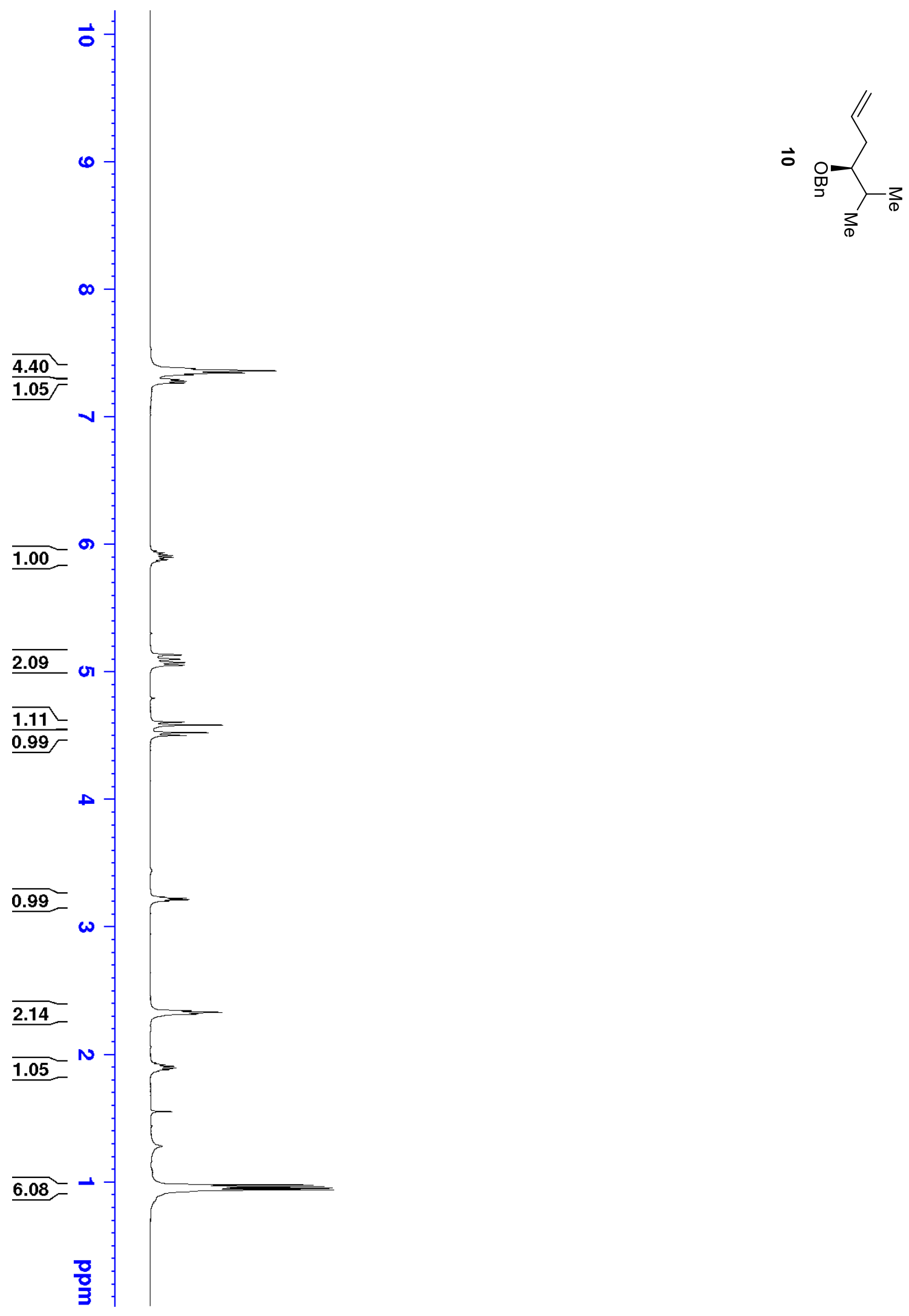

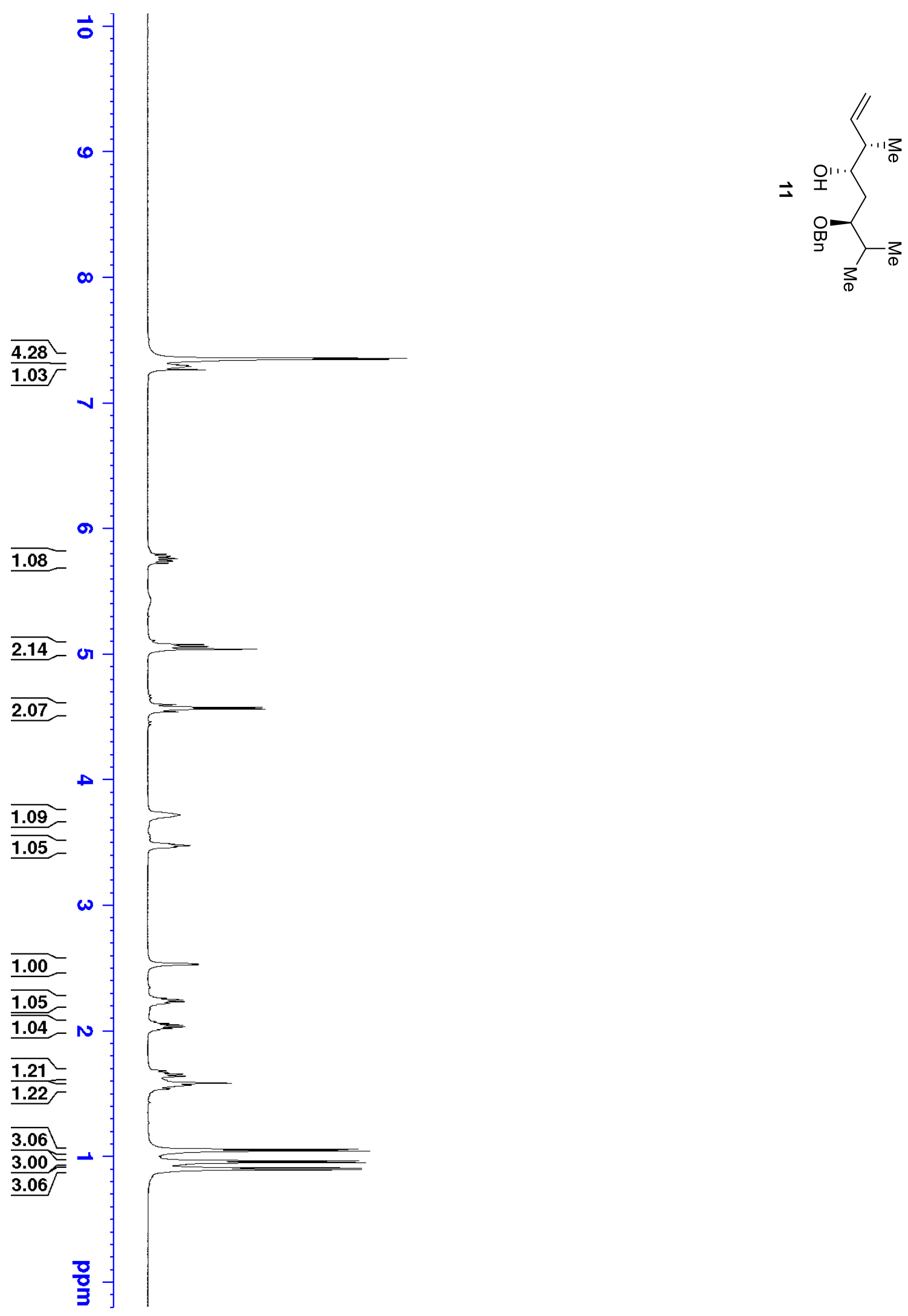


$$
\text { H }
$$




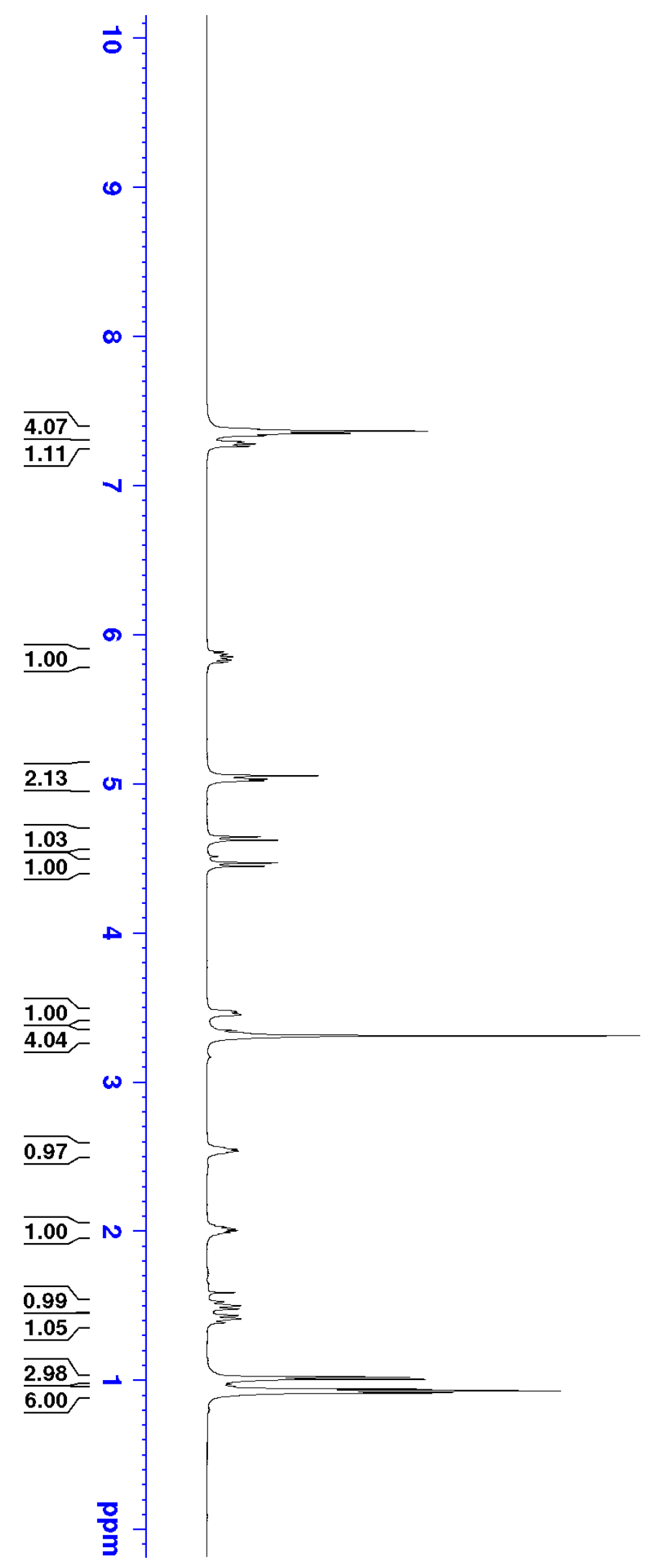




$$
1
$$



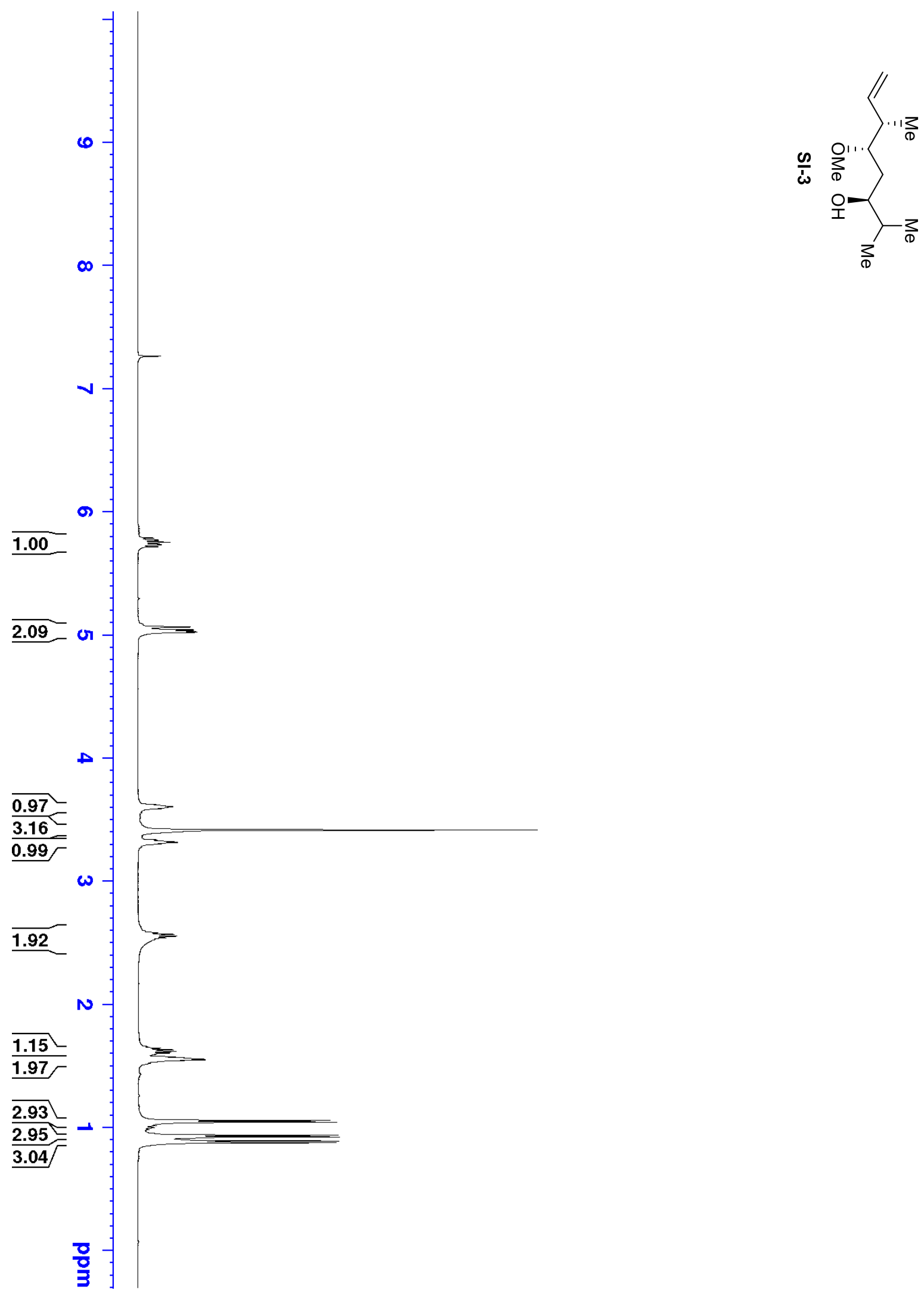


$$
11
$$



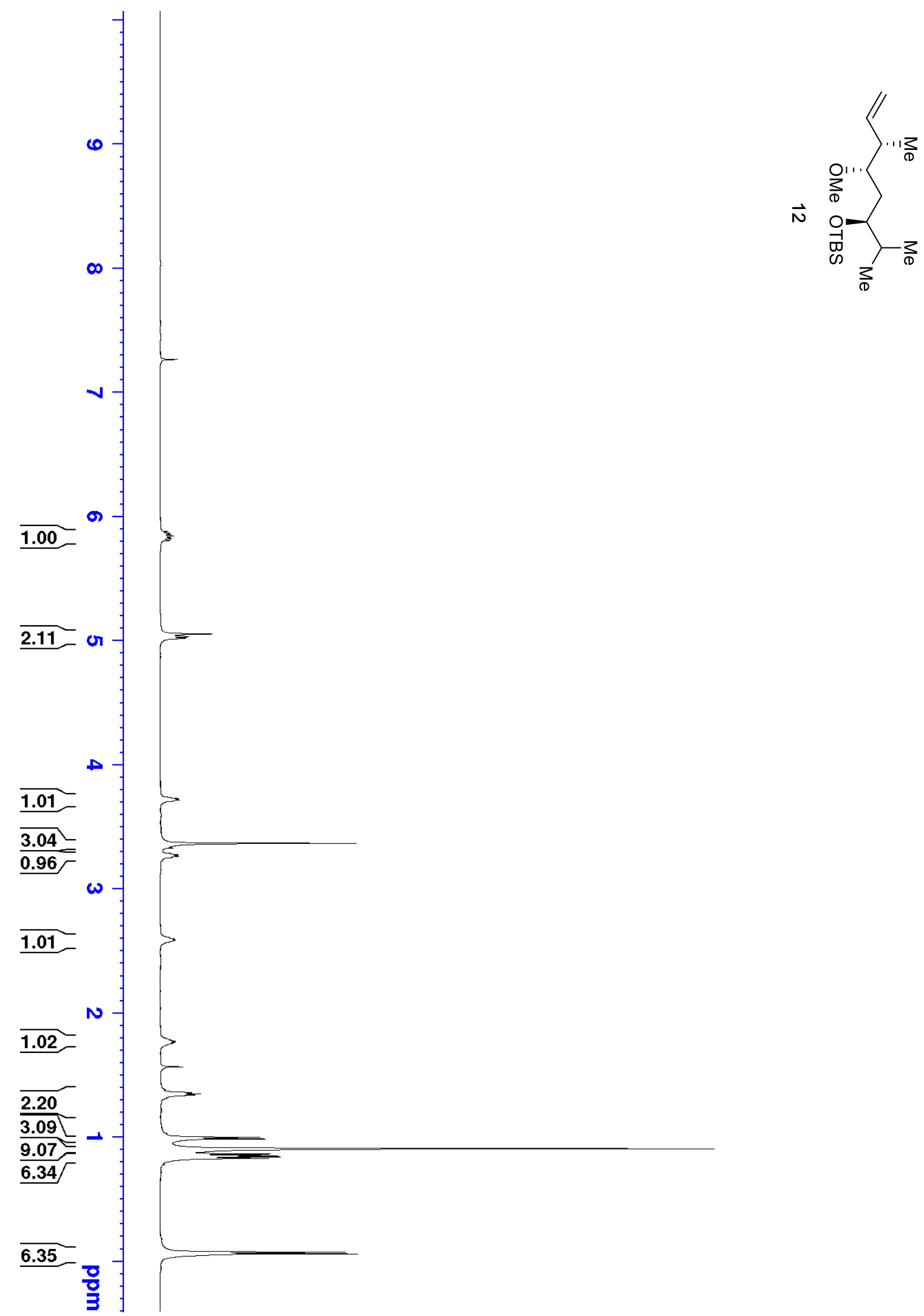


$$
\mid
$$



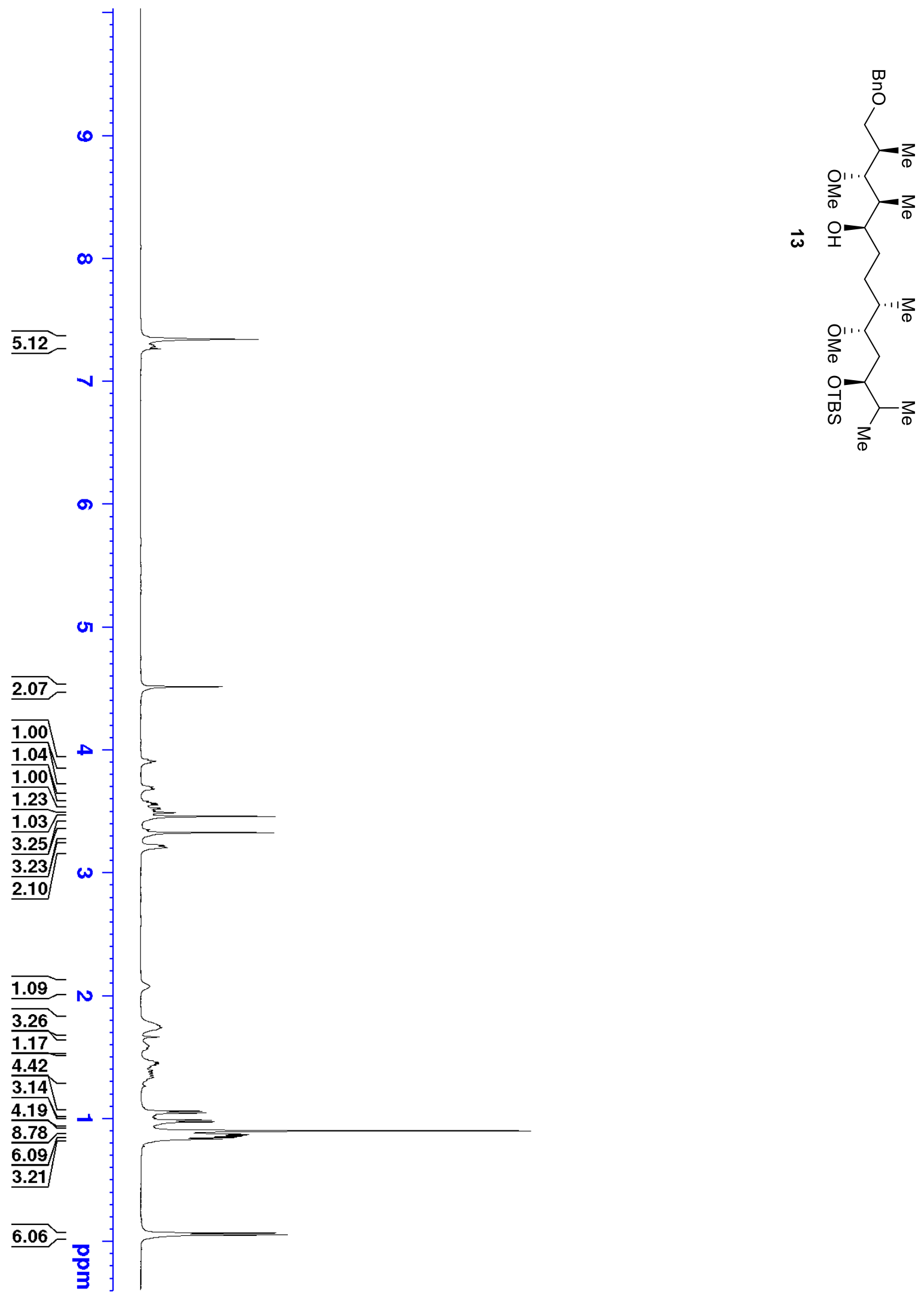


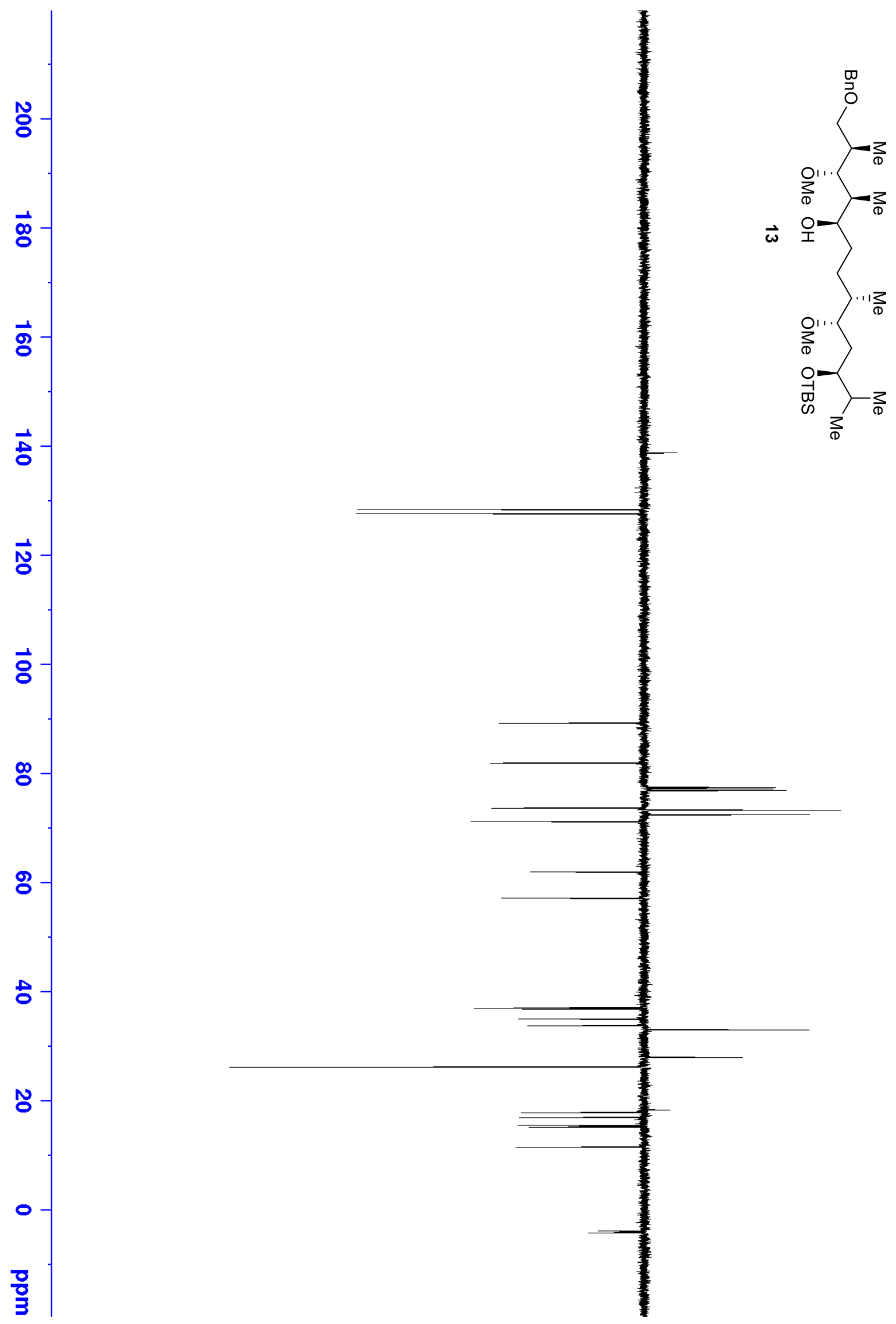




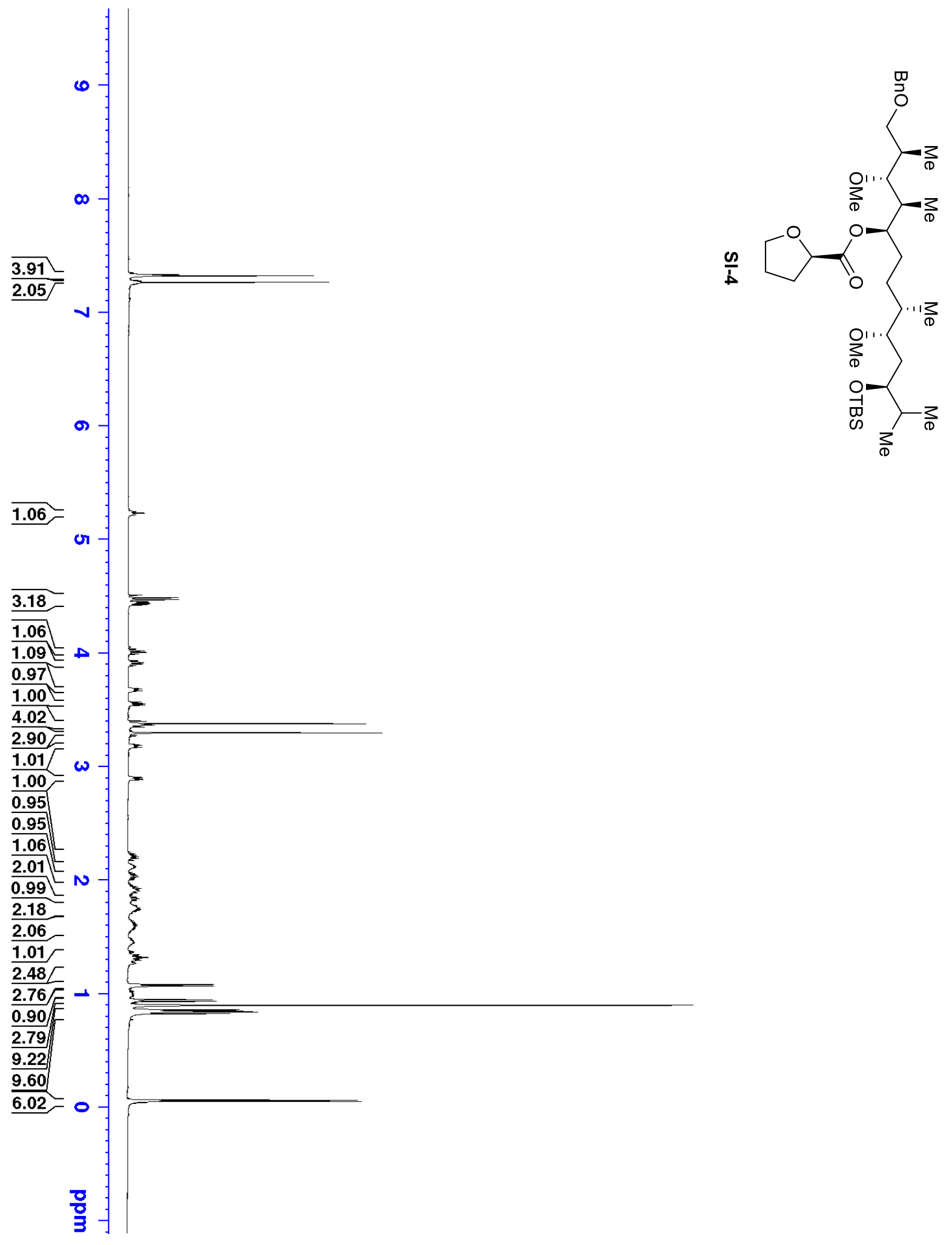




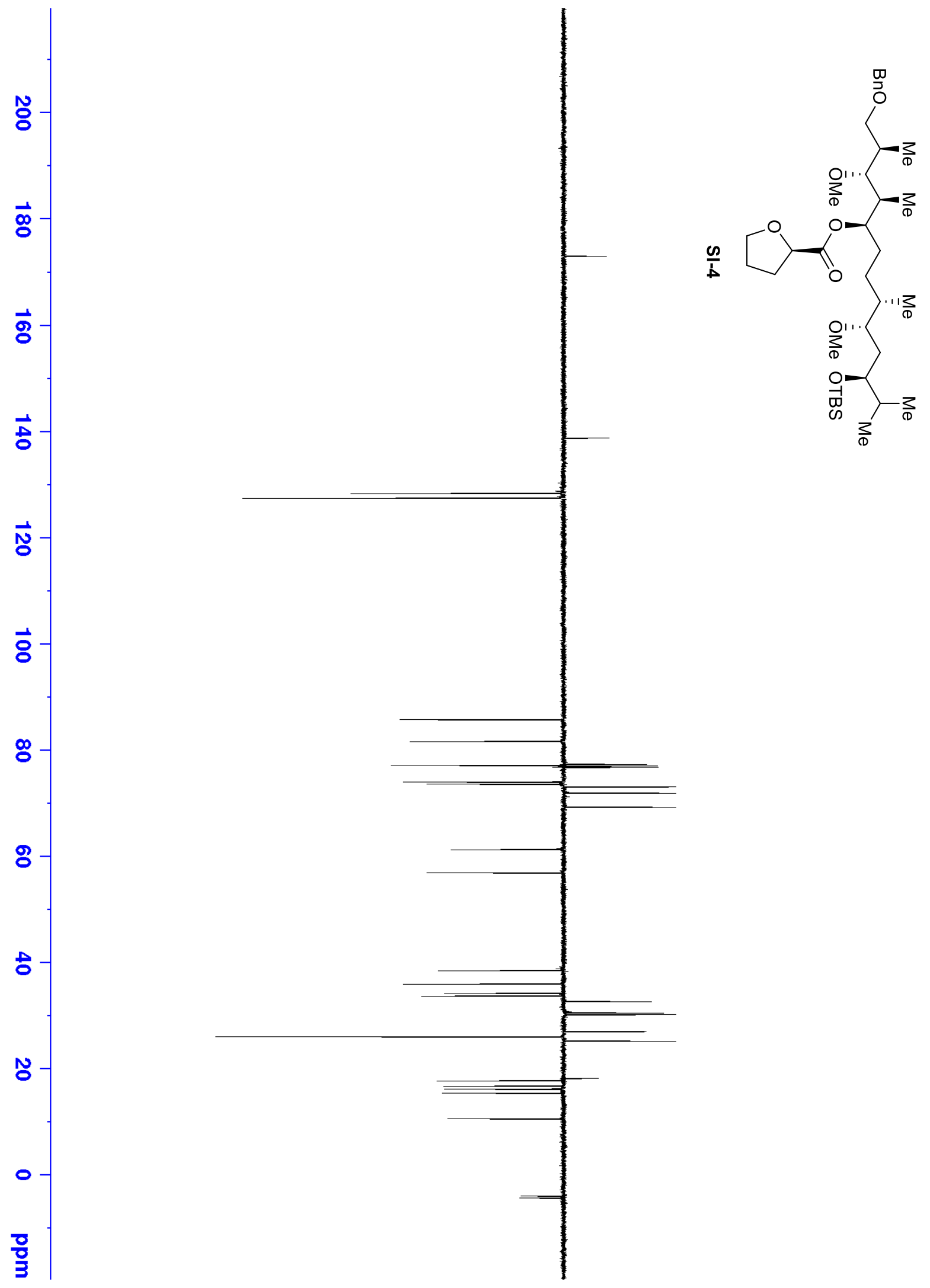




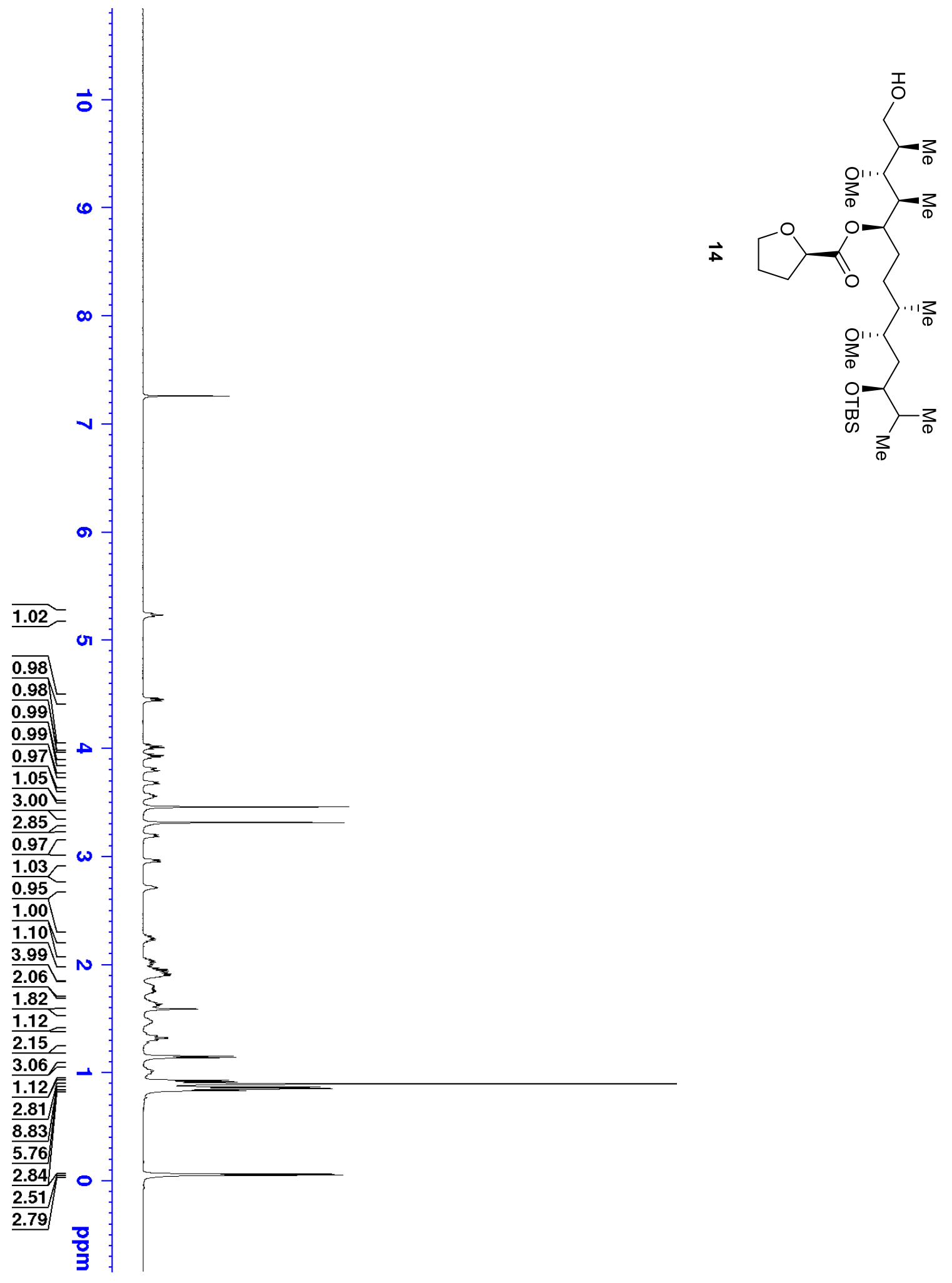




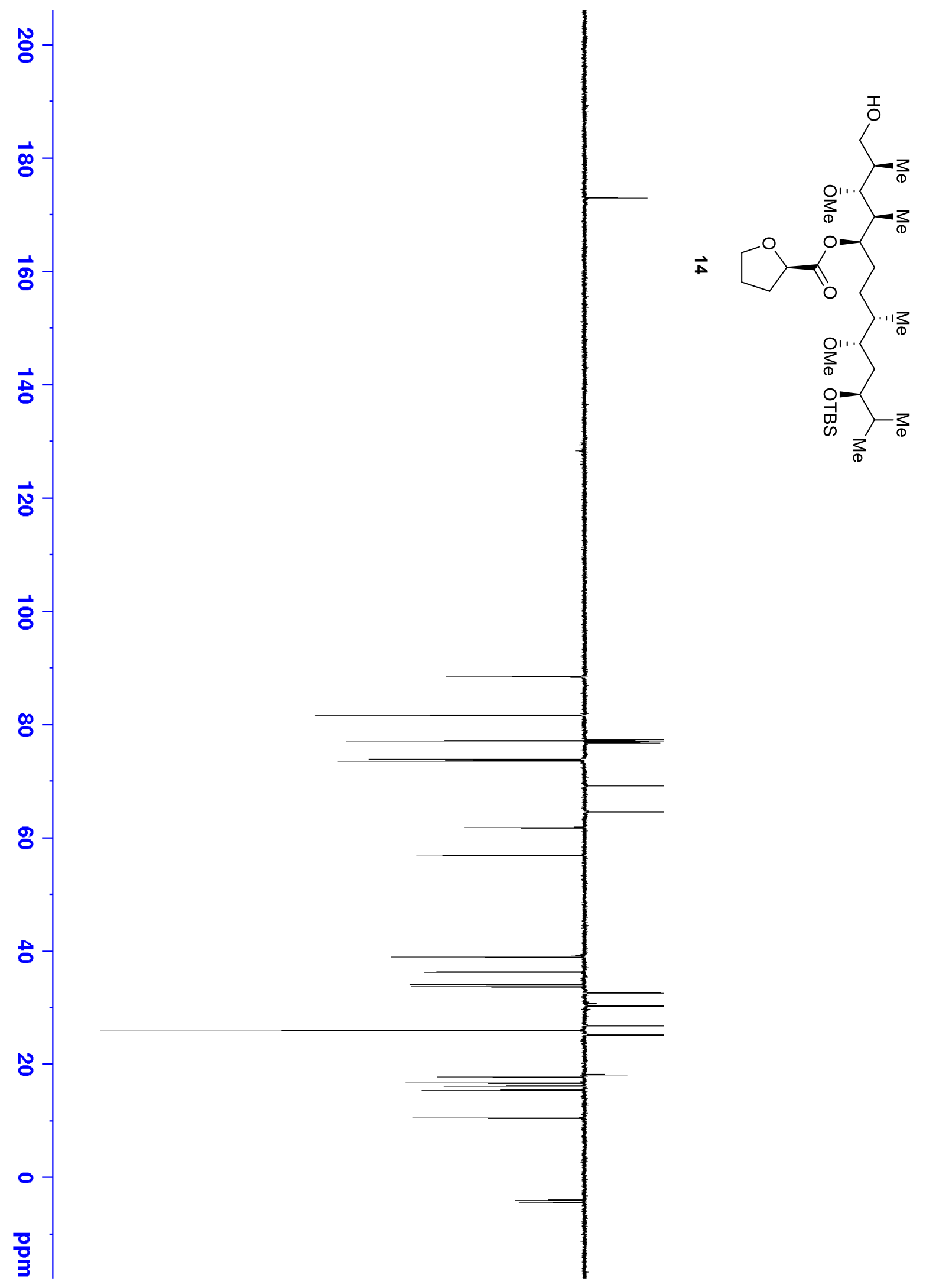



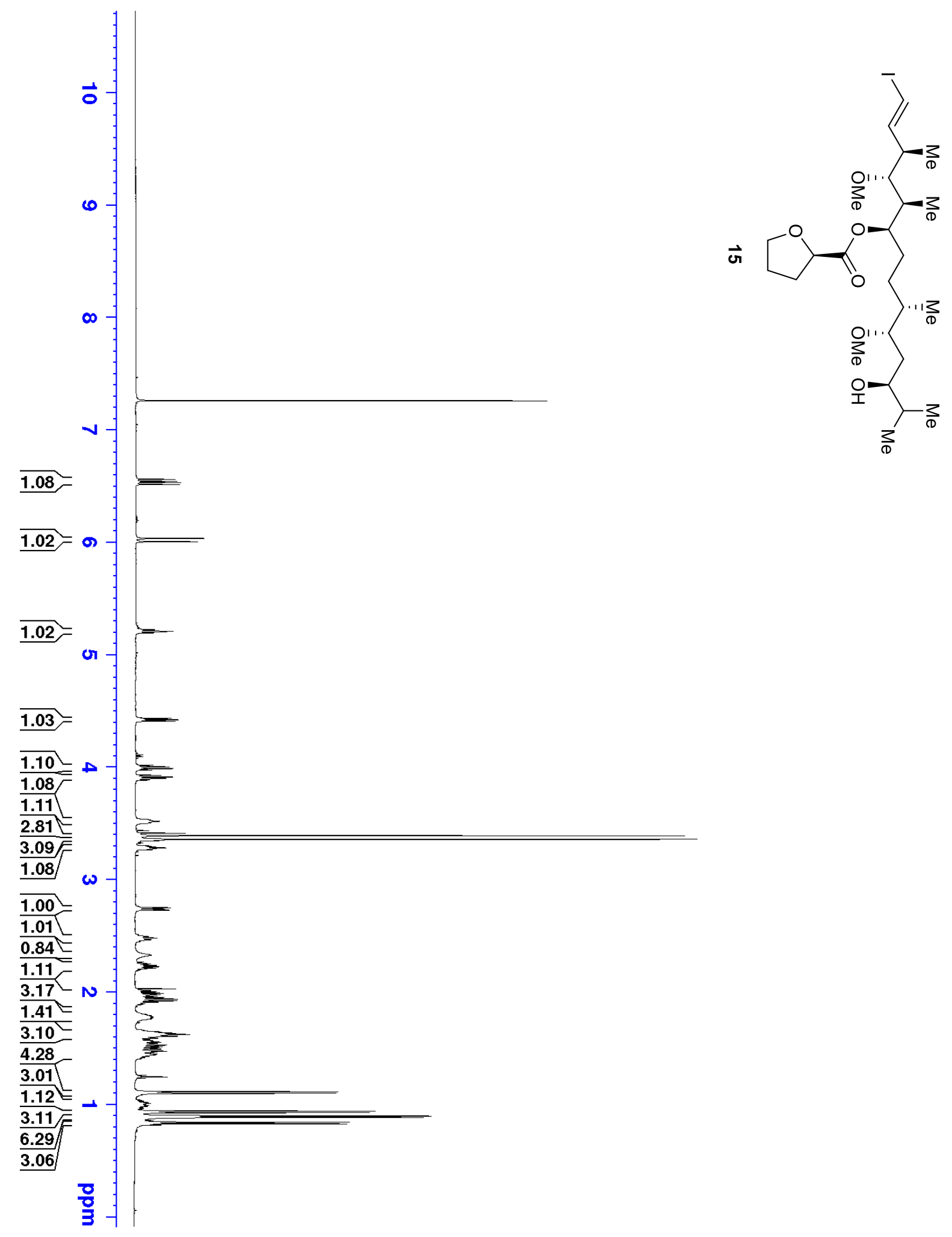


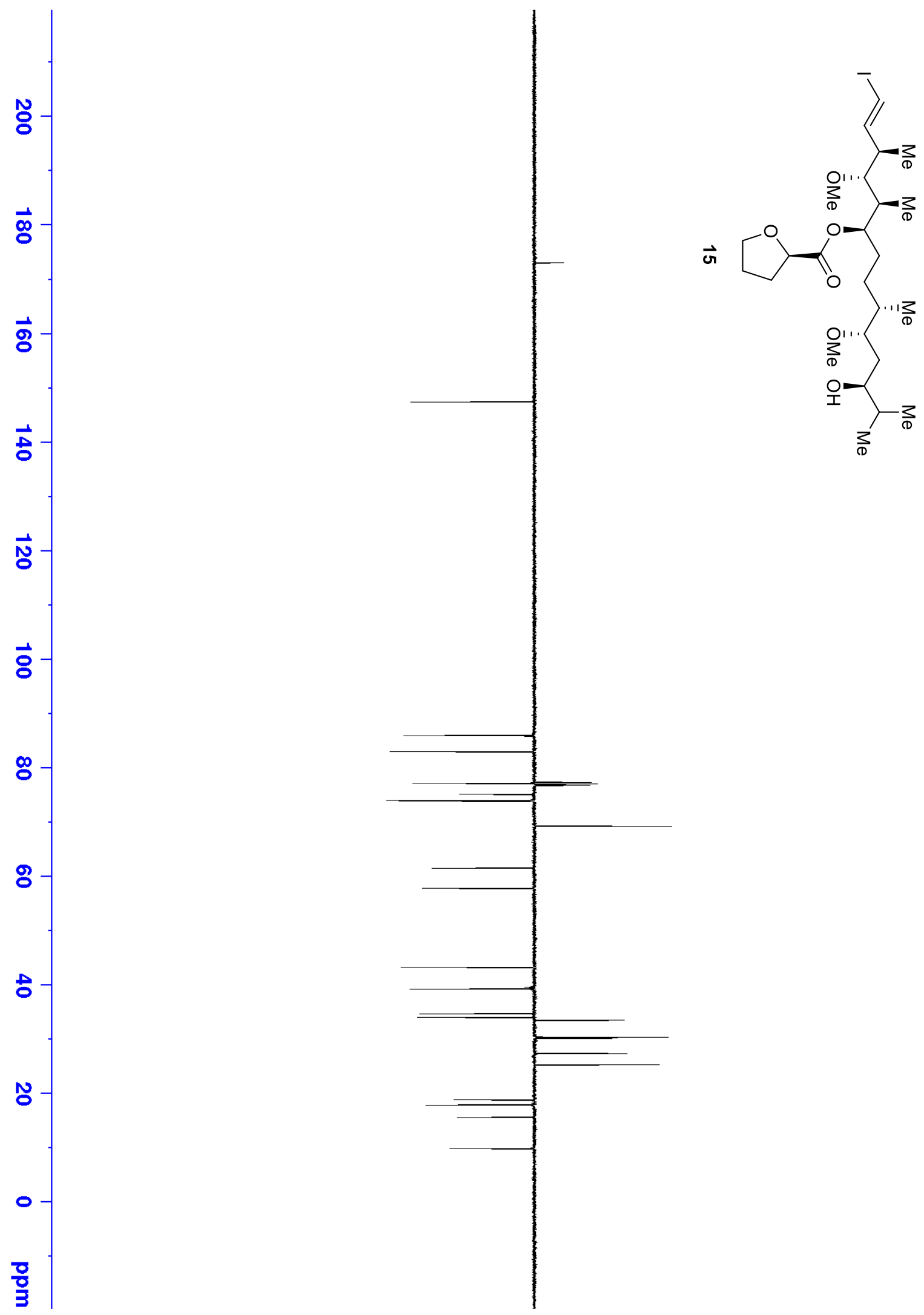




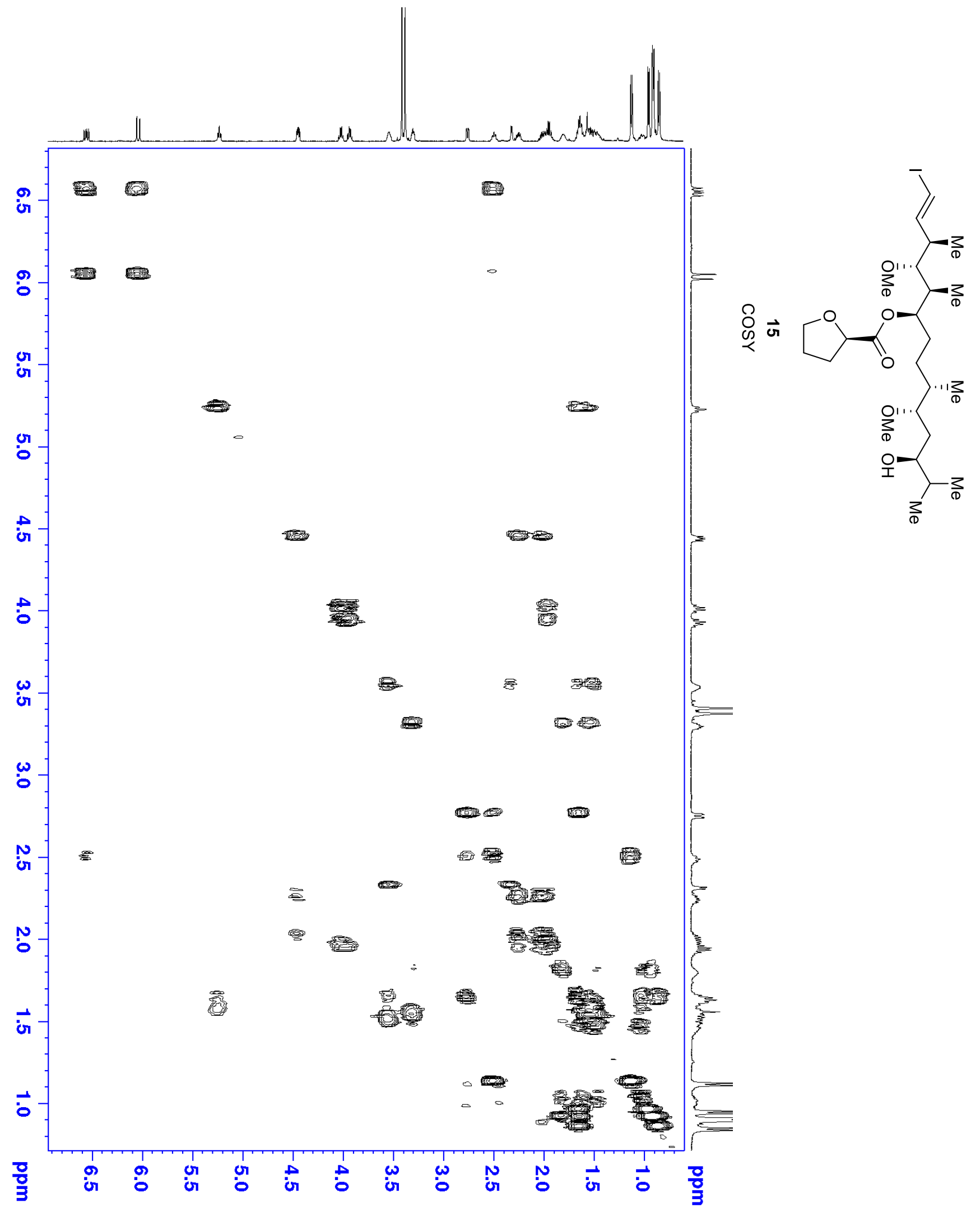



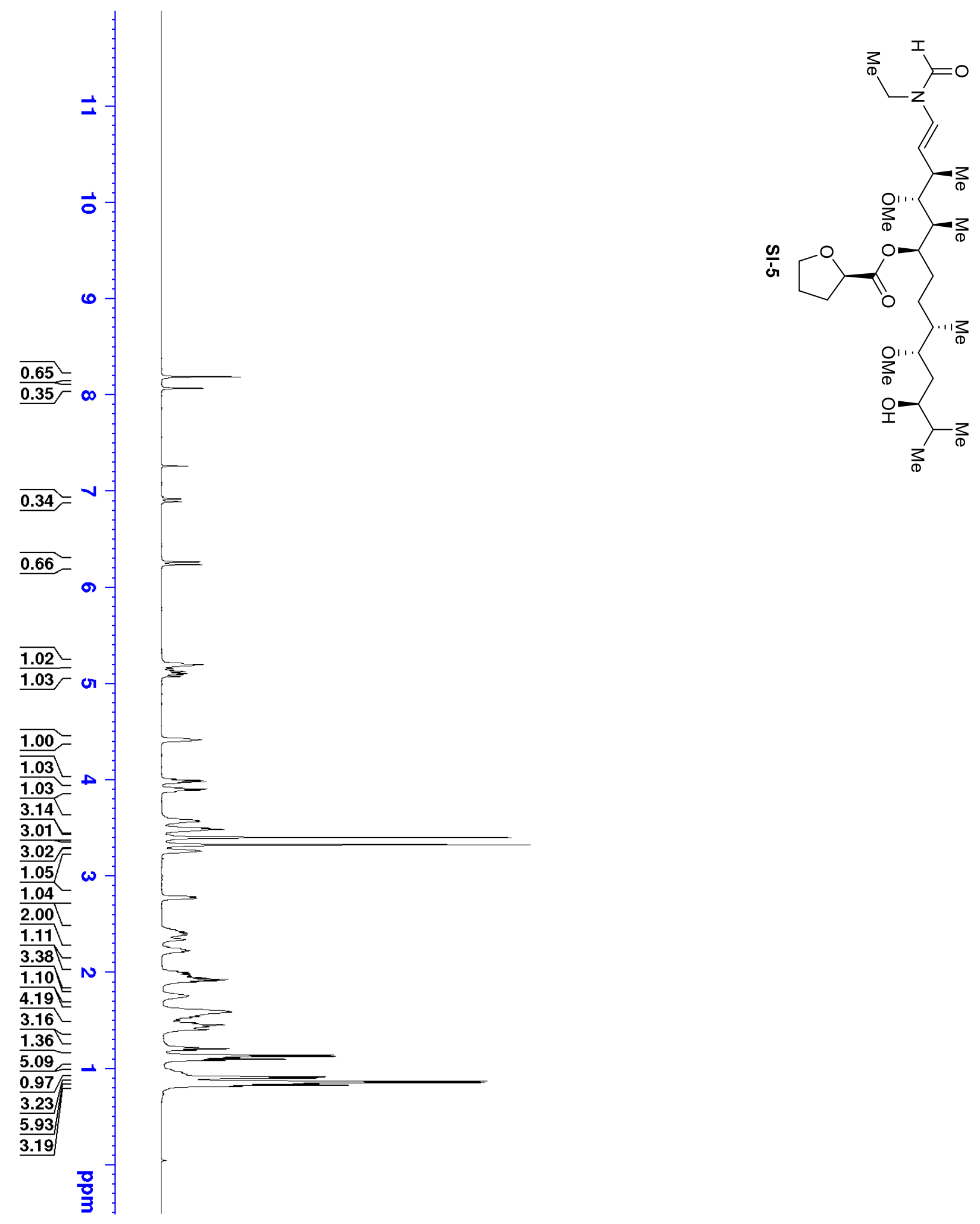

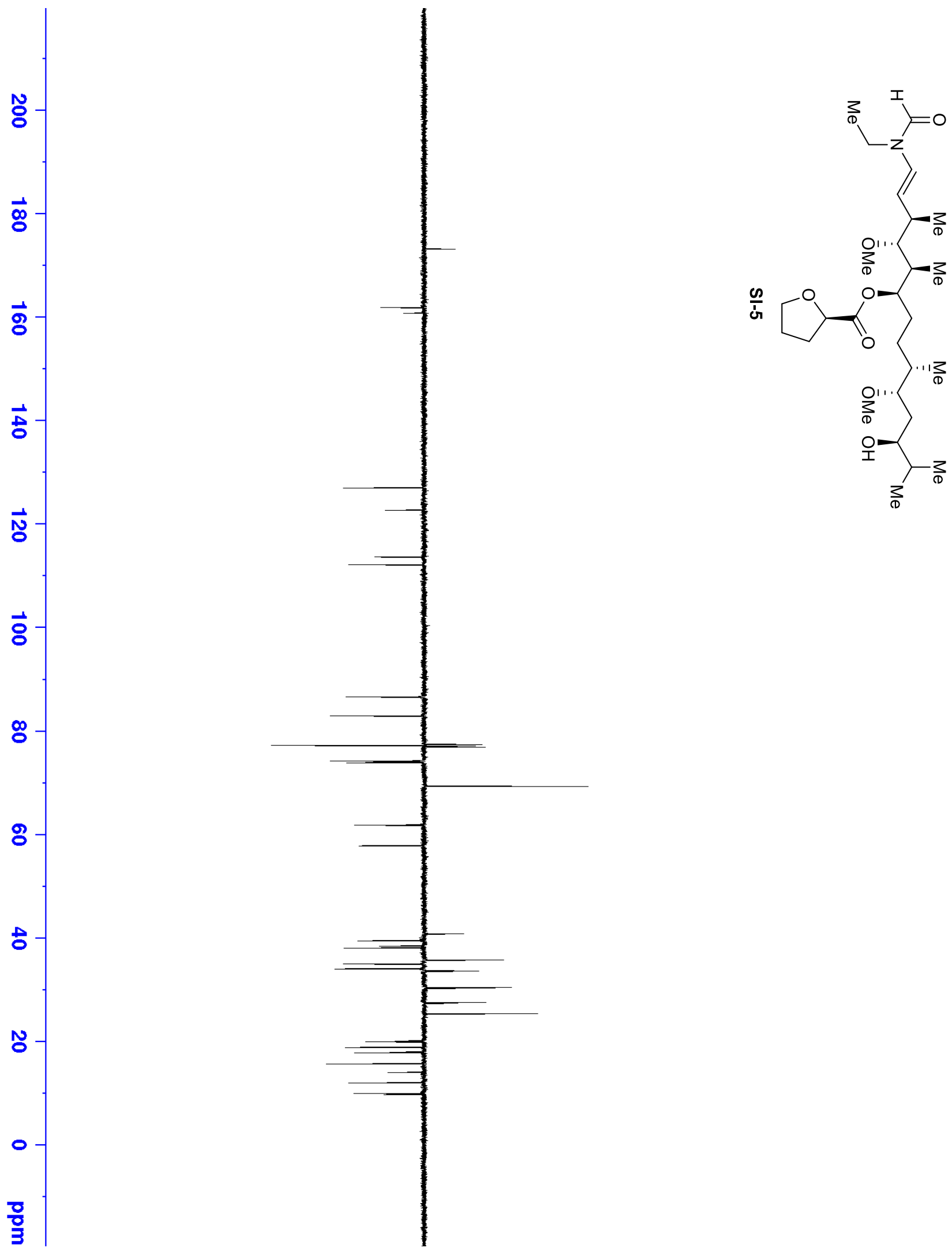


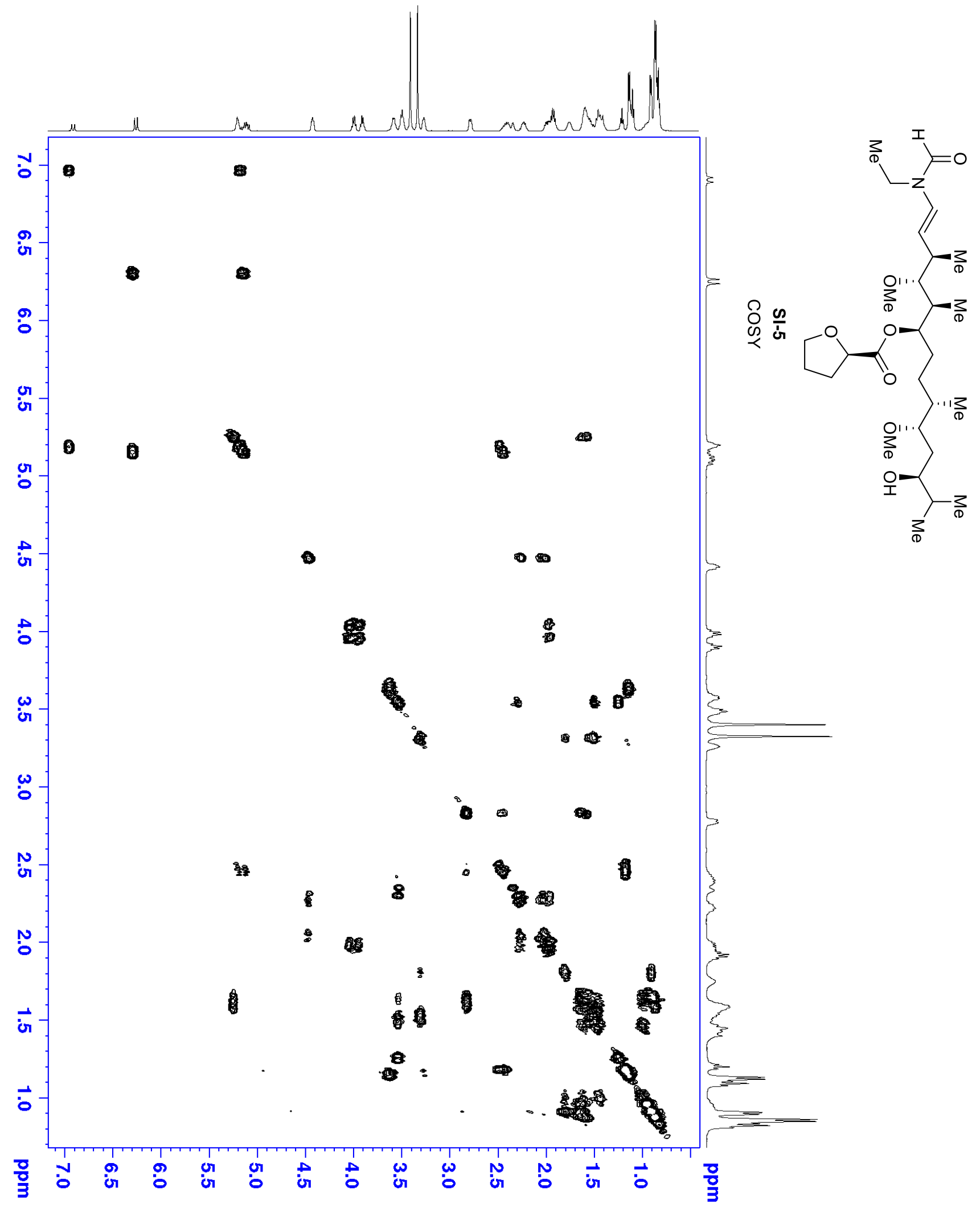



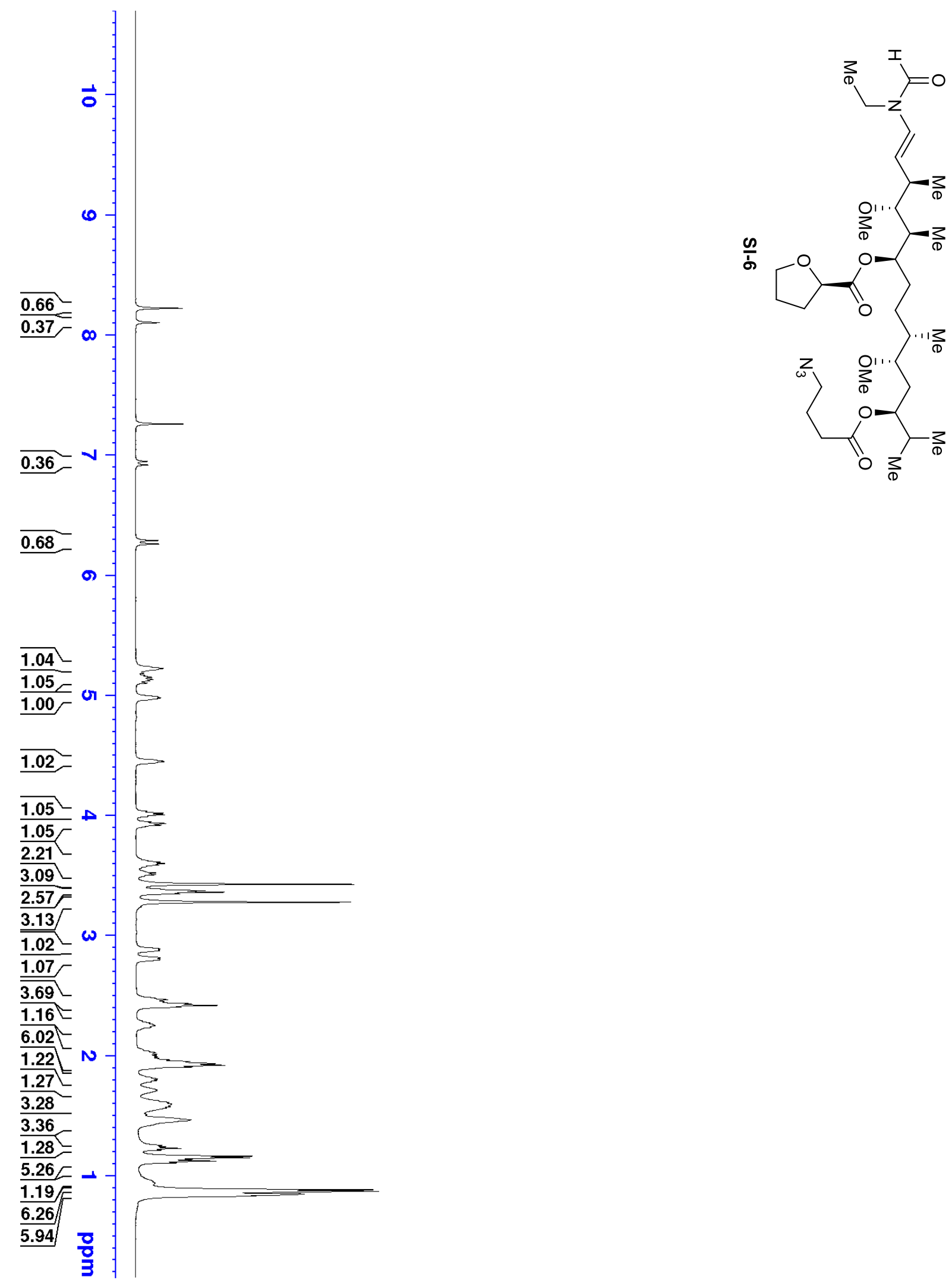

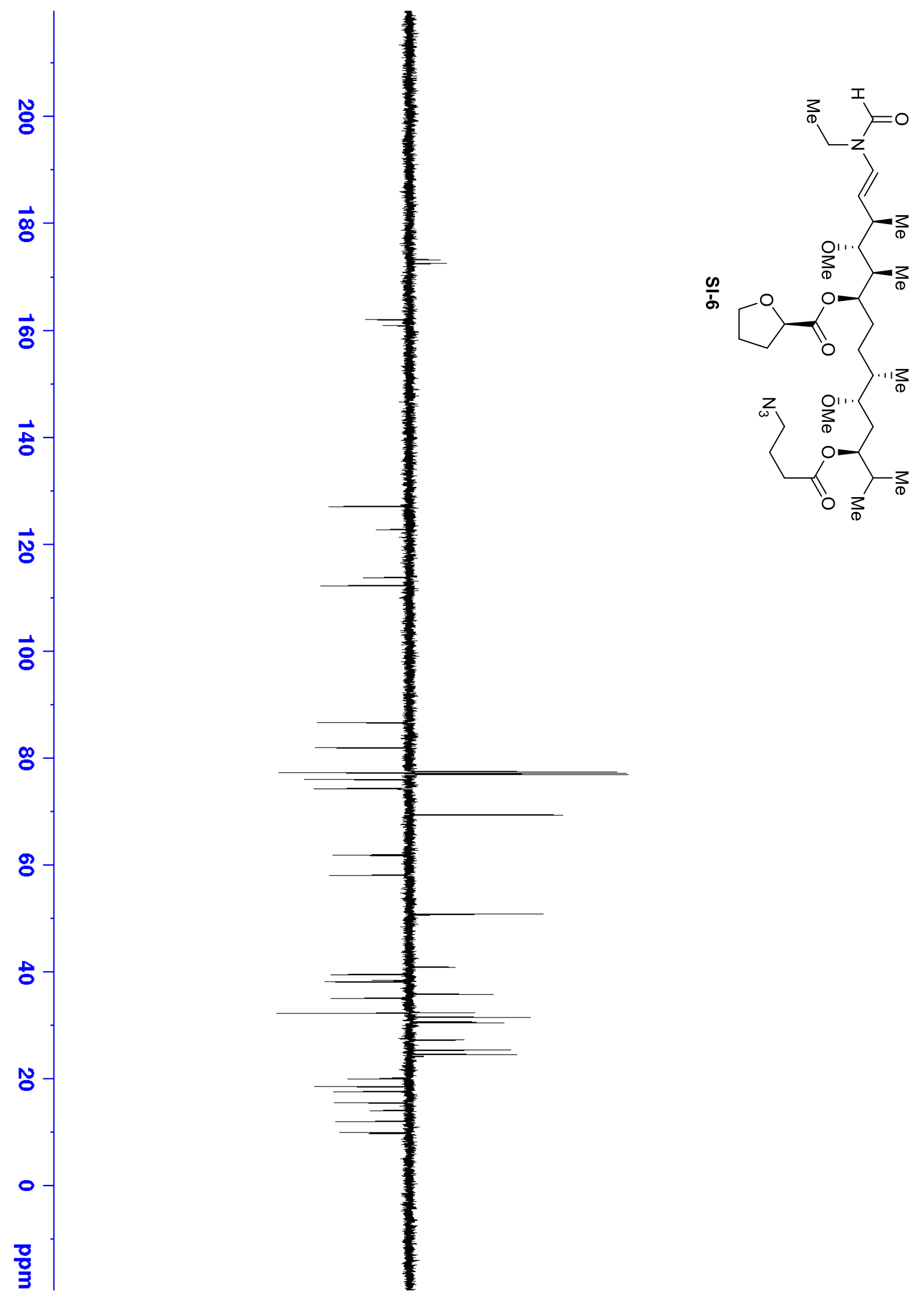


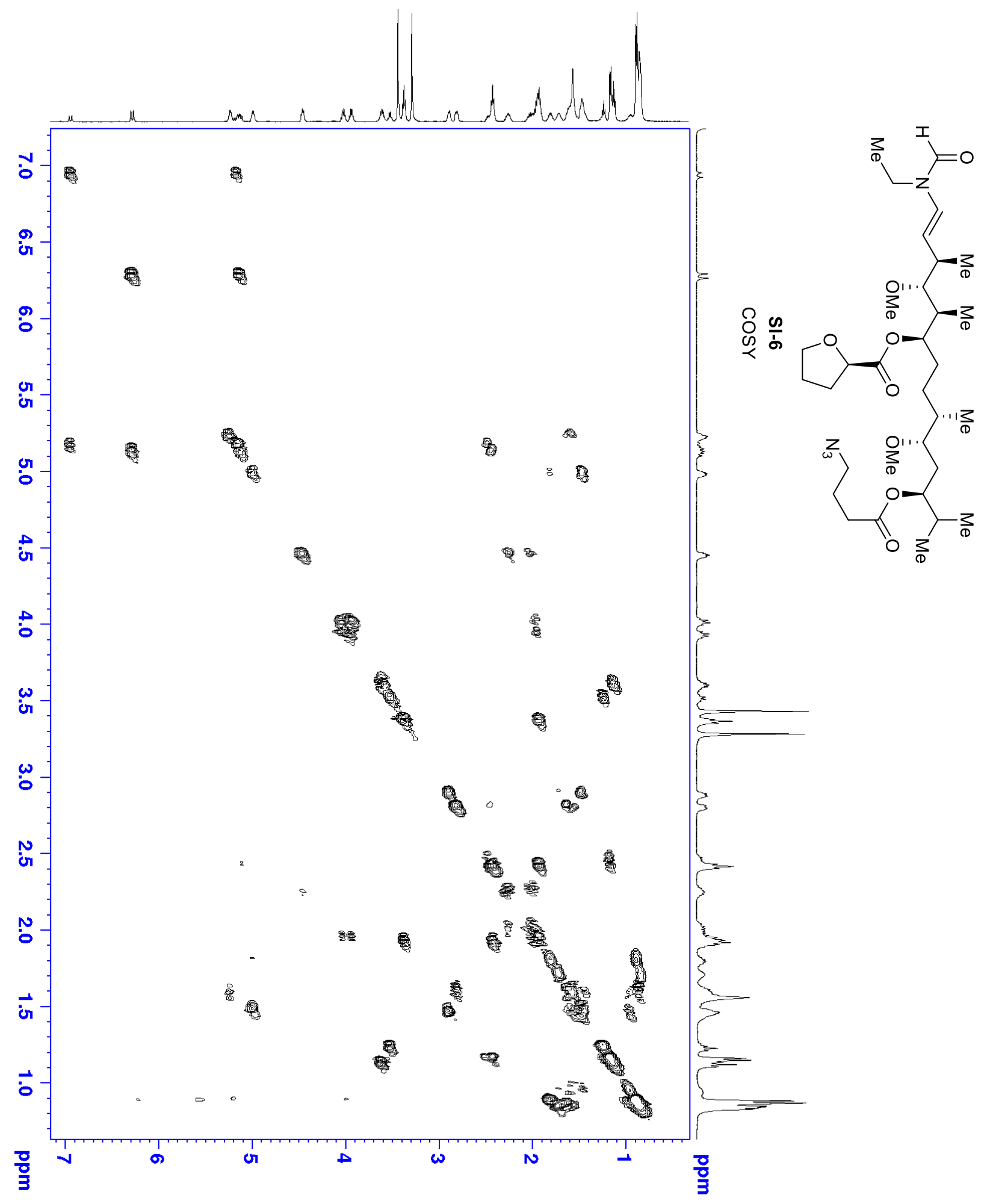



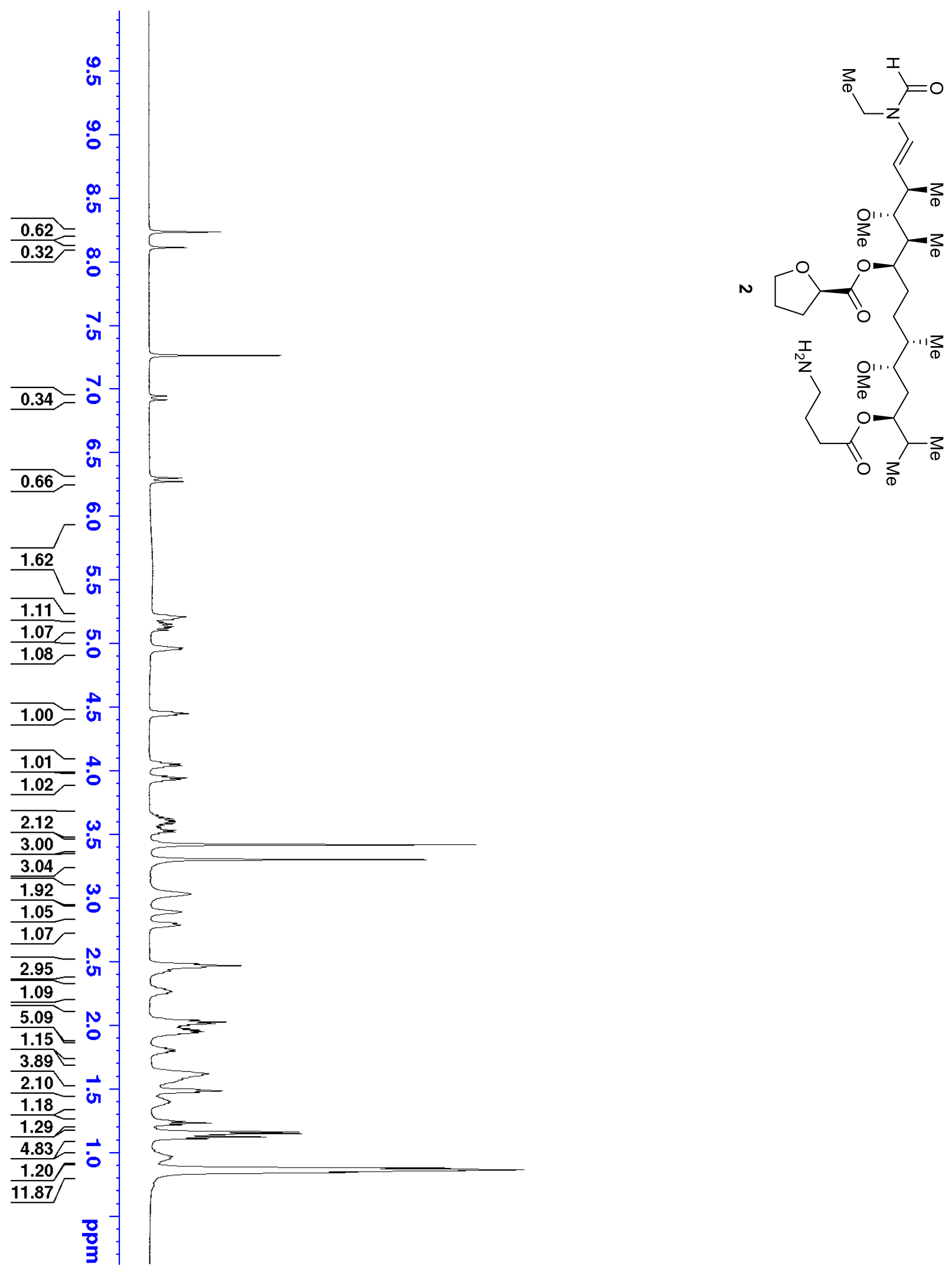


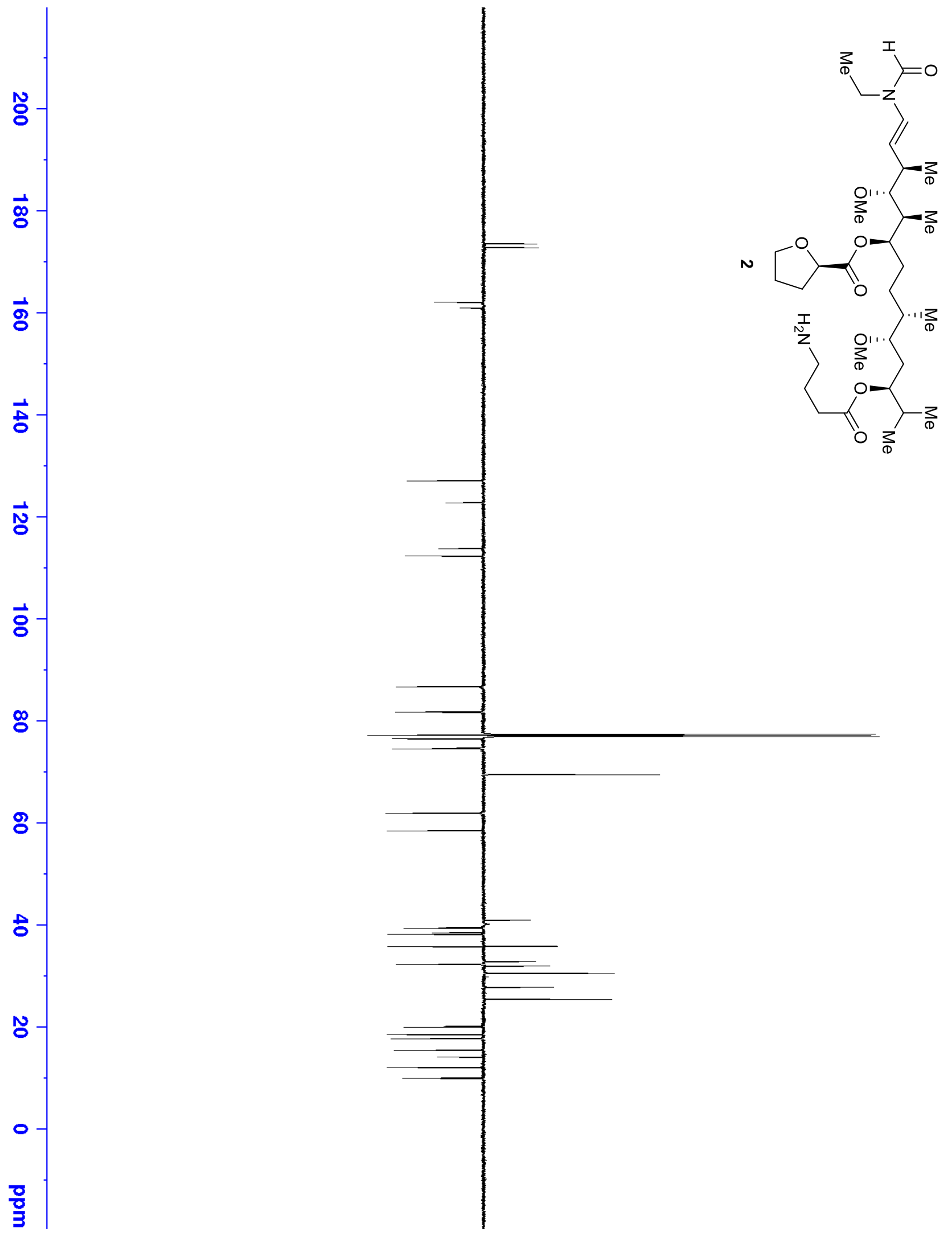




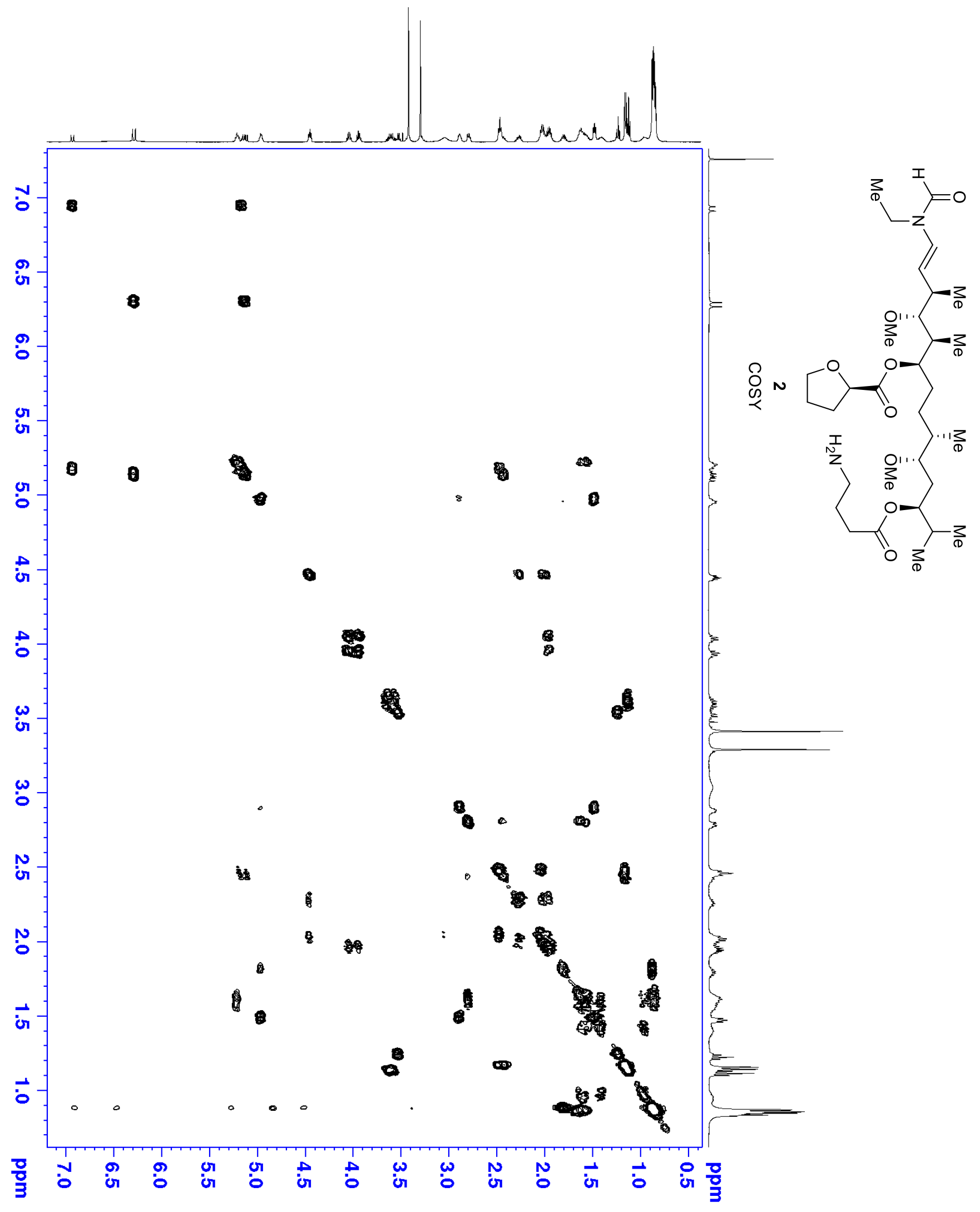

